
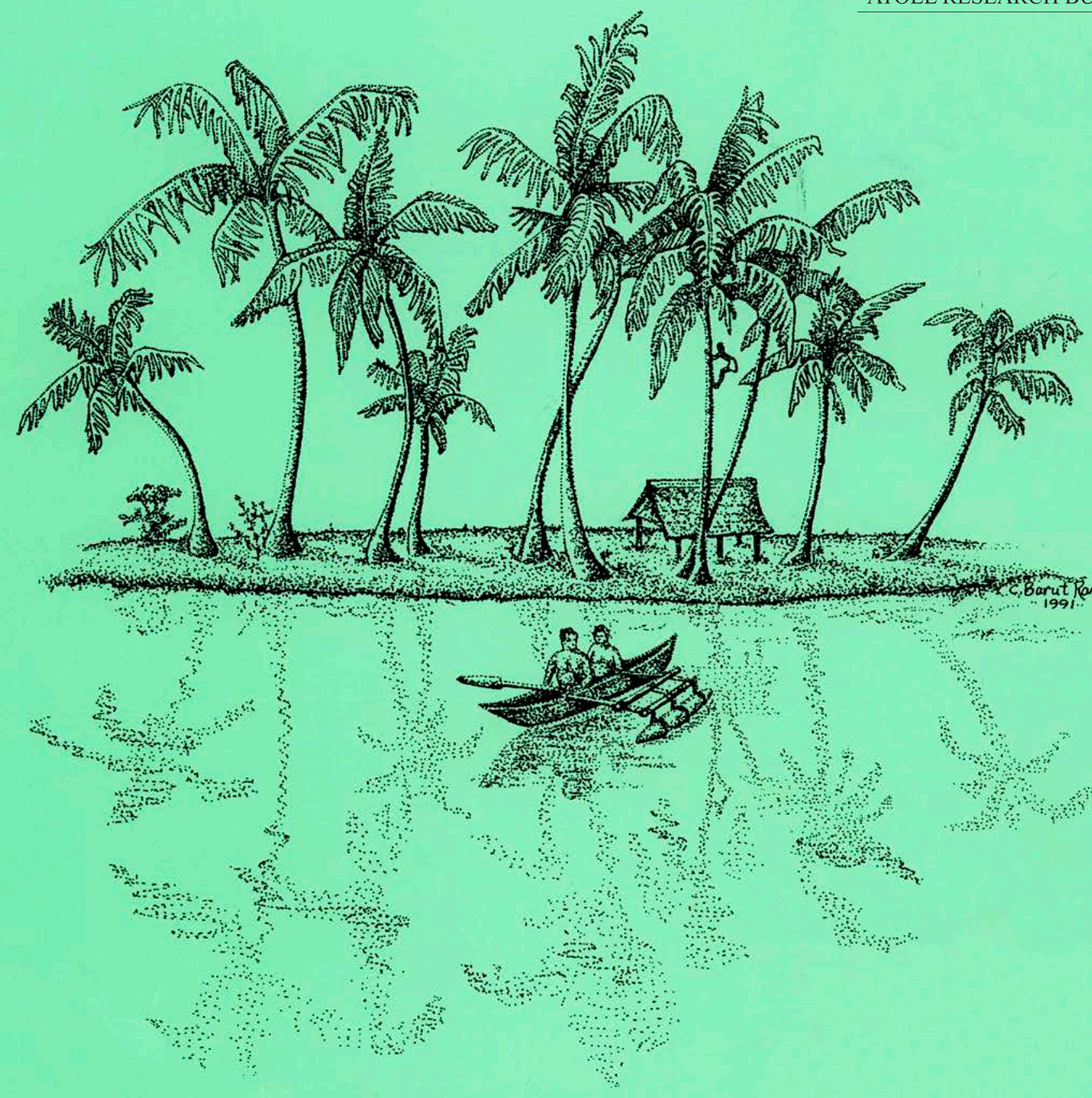

ATOLLS OF THE WORLD:

REVISITING THE ORIGINAL CHECKLIST

ATOLL

Walter M. Goldberg

RESEARCH

Smithsonian Institution
Scholarly Press

BULLETIN 


\section{ATOLLS OF THE WORLD: REVISITING THE ORIGINAL CHECKLIST}

Walter M. Goldberg

Atoll Research Bulletin No. 610 • 28 June 2016 Scholarly Press

Washington, D.C. 
All statements made in papers published in the Atoll Research Bulletin are the sole responsibility of the authors and do not necessarily represent the views of the Smithsonian Institution or of the editors of the bulletin. Articles submitted for publication in the Atoll Research Bulletin should be original papers and must be made available by authors for open access publication. Manuscripts should be consistent with the "Author Formatting Guidelines for Publication in the Atoll Research Bulletin." All submissions to the bulletin are peer reviewed and, after revision, are evaluated prior to acceptance and publication through the publisher's open access portal, Open SI (http://opensi.si.edu).

Published by SMITHSONIAN INSTITUTION SCHOLARLY PRESS

P.O. Box 37012, MRC 957

Washington, D.C. 20013-7012

www.scholarlypress.si.edu

The rights to all text and images in this publication are owned by either the contributing authors or third parties. Fair use of materials is permitted for personal, educational, or noncommercial purposes. Users must cite author and source of content, must not alter or modify the content, and must comply with all other terms or restrictions that may be applicable. Users are responsible for securing permission from a rights holder for any other use.

ISSN: 0077-5630 (online) 


\title{
ATOLLS OF THE WORLD: REVISITING THE ORIGINAL CHECKLIST
}

\author{
WALTER M. GOLDBERG ${ }^{1}$
}

\begin{abstract}
There is only one published list of atolls of the world (Bryan, 1953) and it is the source of the oftenquoted figure that there are 425 or "more than 400 " of them. However, the original compendium included many banks and other reefs without lagoons. A re-examination of Bryan's data, along with charts, satellite photographs and updated literature suggests that the number of atolls is indeed "more than 400," despite the deletion of more than 100 of his entries. There are 439 atolls identified in the present summary, but the list is broadly constructed, inclusive, and not limited to those known to have formed on subsiding volcanic platforms. In addition, 171 of those listed (39\%) are primarily subtidal atoll reefs with little or no island development. These particular atolls comprise 96\% of those from Fiji, 94\% of those in the South China Sea, and $62 \%$ of those in Indonesia. With few exceptions, all of these reef systems are specifically identified and verified using Google Earth, Landsat or other satellite imagery, making this group an important and under-appreciated element of atoll geomorphology. Eliminating atoll reefs from consideration reduces the list of atolls to 268. Of these, 104 are closed and lack a direct passage connecting the lagoon and the surrounding ocean. Closed lagoons are typical of atolls in French Polynesia (53 of 78 with lagoons), even though most of them are euhaline and are open to exchange of ocean water by indirect mechanisms. By contrast, many atolls in the central Pacific, including most of those in Tuvalu, the Phoenix Islands and the Line Islands, have developed isolated lagoons containing hypersaline, brackish, and even fresh water. The location and type of atoll (atoll reef, and atolls that are open, closed, or closed with altered lagoon salinity/oxygen) are specified on maps and tables appended to this work, and a photographic record of all but two of 439 atolls has been assembled as a supplement. This list is by no means complete. There are numerous atolls or atoll-like structures that do not have a satellite record or an adequate description on charts or in the literature. This is especially true of Indonesia, Fiji and islands east of Papua New Guinea where further exploration is likely to increase the number of entries.
\end{abstract}

\section{INTRODUCTION}

Atolls have always been evocative and seductive reef structures, and once geologists and biologists started wondering how many there are, that number became a question of high interest. However, few studies address the answer, and indeed, given their global nature and variability of form, an exact number may be difficult to come by, or to agree upon. Edwin H. Bryan, Jr. (Figure 1) started as a curator of botany and entomology at the Bernice P. Bishop Museum in Honolulu in 1919 and stayed there for 60 years, a period that was interrupted only by World War II. Islands, atolls in particular, fascinated him, and having traveled to so many, he decided to tally how many there were. His checklist (Bryan, 1953) included those with lagoons and islands, as well as limestone structures with dry land and no lagoon. However, he excluded submerged atolls and he often (but not always) excluded atolls next to high islands and other landmasses to avoid confusion caused by atolls keeping close company with other types of reefs. He also excluded atolls that had been uplifted. His grand total was 409, although he hedged that figure, noting that some in his list were not typical, and when those explanations were factored in, the number became "about 400."

${ }^{1}$ Florida International University, Department of Biological Sciences, Miami, FL 33199; email: goldberg@fiu.edu 


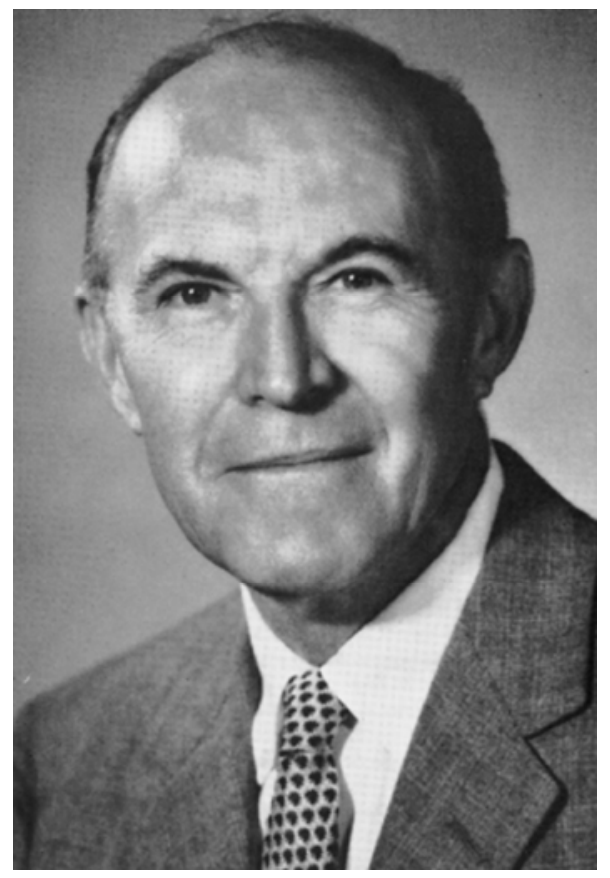

Figure 1. Edwin H. Bryan, Jr. (18981985), curator of entomology at the Bishop Museum and author of "A Check List of Atolls." Courtesy of the Pacific Science Association, Honolulu.
Bryan's list was challenged almost immediately by Cloud (1953) who suggested that it was inflated by the inclusion of roughly sixty table reefs (described below). Cloud also took issue with the inclusion of 26 atolls in the Caribbean that he categorized as submerged banks, and in conclusion, he estimated that there are "330 or so known and probable atolls."

By considering only those arising from deep ocean basins, Menard (1986) lowered Cloud's number to 261, although he gave no basis for that determination. Stoddart (1965) was a bit more accepting of Bryan's list, but counted the entries a little differently by including the northern and southern halves of the same structure in the Maldives, and others that Bryan included as subsets of a single atoll. That resulted in Bryan's count becoming 425, although Stoddart agreed that taking table reefs and lagoonless banks out and adding new information made "about 400" seem right. Those two numbers, 425 and 400, have been quoted many times ever since (e.g., Guilcher, 1988; Kinsey and Hopley, 1991; Andréfouët et al., 2001; Bailey and Jenson, 2014; Gischler, 2016). Bryan's data are worth reexamining after more than 60 years. There is a considerable literature that has developed, including a few comprehensive regional studies that have taken place in the interim, a coral reef atlas of the world (Spalding et al., 2001), and an extensive satellite record, to augment that information. The present work is a re-evaluation of Bryan's list.

\section{Atoll Islands and Rims}

An all-encompassing definition of atolls should require an assessment of their wide variation in form, as well as their numerous exceptional features. Wiens (1962) presented the long version, which included three and a half pages of text, four figures and a table. Ladd (1977) gave a more parsimonious and unsatisfyingly brief definition of an atoll as an annular reef whose rim develops at or near the sea surface and encircles a deeper lagoon. Gischler (2016) added more texture, describing them as circular or irregularly shaped, isolated oceanic reef structures at or near sea level that enclose a lagoon usually tens of meters deep. The shallow and partly emergent margin of atolls contains the rim and its components (the reef crest, the reef flat, sand apron and marginal islands), the sum of which is typically much smaller than the lagoon area. These elements are briefly described below.

MacNeil (1972) divided coral islands into three types, including those forming on platforms or eroded remnants of the rim, on tracts of coralline storm debris, and on sand bars or beach rock. Islands on atolls are typically low (2-4 m) and are composed of biologically derived carbonate sand, gravel and reef rubble, the development of which is driven by the prevailing oceanographic climate, including proximity to the trade-wind belt and the prevalence of cyclones, storms and swell (e.g., Woodroffe, 2011). In areas of low storm frequency, islands are often built as sand cays from unconsolidated reef sediments, whereas in areas where storms are more common they tend to be rimmed by shingle and gravel, especially on the windward side, and are sometimes referred to by their Polynesian name, motu (Stoddart and Steers, 1977; McLean, 2011). Atoll islands are often asymmetrically distributed toward the windward side, although symmetrical island formation may occur around the rim in regions exposed to monsoonal wind reversals or frequent El Niño conditions (Kench et al., 2006; Woodroffe, 2008).

Reef flats are the most recent expression of coral reef growth at sea level and may exhibit coraldominated and rubble-dominated forms, depending on the relative wind and wave energy conditions to 
which they are exposed (Thornborough and Davies, 2011). Atoll reef flats are $<100 \mathrm{~m}$ to $>1,000 \mathrm{~m}$ wide and are especially well developed on the windward side where much of it is exposed at the lowest tides. However, on some atolls, including South Keeling (eastern Indian Ocean), the windward flats are 801500 m wide (Kench, 1998) and thus exhibit the full spectrum of variability. On coral-dominated reef flats, distinct zones may be evident, including the reef crest, where coralline algae often dominate. Shoreward (or lagoonward) of the crest, a pavement-like veneer of coralline algae often merges with corals in a backreef environment, which may become moderately diverse in pools that are deep enough to protect their residents from exposure or extreme water temperatures. A thin band of rubble may develop as an inner zone on coral-dominated reef flats, but broken pieces of coral shingle and boulders are common on high-energy atoll shores, where they are transported en masse by storms and are later sorted by wave activity.

Carbonate sediment produced on the reef flat is subsequently transported shoreward by hydrodynamic forces and may make the lagoon a major site of sand deposition. Consequently, a sandy and shallow lagoon margin, the apron, is a prominent and typical feature of atoll rims (e.g., Rankey and Garza-Perez, 2012). This geomorphic characteristic has a major role in filling in the lagoon where platform size, topography, and sea level changes facilitate the shoaling process. The lagoon on Midway Atoll, for example, exhibits a wide apron, suggesting that it is actively being filled, and the apron in Wreck Reef's 1 m deep lagoon (Coral Sea, Australia) has nearly completed the process (Isaac and Gischler, 2015).

Likewise, the lagoons of several former atolls in the Tuamotu Archipelago, the Lakshadweep Islands, the western Indian Ocean and elsewhere have become filled with sediment and now occur as islands surrounded by reefs (see below).

Atoll islands began to accrete on reef flats when they were established within the last 1500-4000 years - an interval dependent on geographic location - as previously higher sea levels reached a position close to present (Pirazzoli et al., 1988; McLean and Hosking, 1991; Woodroffe, 2008). While the formation of the reef flat is related to island formation, island age is difficult to determine directly. However, it is clear that for their endurance, islands are dependent on a continuous reservoir of biogenically derived sediment (Woodroffe et al., 2007; McLean, 2011), the supply of which is susceptible to disruption (e.g., Kench and Cowell, 2003; Perry et al., 2008; Perry et al., 2011) and may make the difference between islands that are persistent and resilient and those that are ephemeral or fail to develop. Most atolls present a shallow and partially emergent (2-4 m) rim as described above. However, atolls that occur in shallow water do not necessarily support islands (Newell and Rigby, 1957; Wiens, 1962) but often develop a shallow lagoon and features of the rim that suggest zonation similar to more typical atolls. Such reefs are numerous but poorly characterized, and while distinguishable from drowned reefs by satellite observation, they have been largely ignored as a group. A general description of these atolls is given below.

\section{METHODS}

I began with Bryan's checklist and examined satellite photographs of every available entry. For the purposes of this survey, I relied on the presence of a rim and lagoon structure as seen in Landsat Natural Color or other satellite imagery, including NASA's Image Science and Analysis Laboratory (http://earth.jsc.nasa.gov) and Google Earth. These were supplemented where necessary using National Geospatial-Intelligence Agency (NGA) or British Admiralty maps or University of Texas Pilotage Charts available online. Atolls must have a lagoon and a rim with or without islands. I distinguished those with navigable passages through the rim (open lagoons) from closed lagoons that lack such entrances in Appendix A, as well as those with lagoons that are diminished (but not eliminated) by sediment filling or by other means. I have also made particular effort to identify closed systems with hypersaline, brackish, and fresh water (Appendix B, Table B.1). 


\section{Atoll Morphology}

Atolls exhibit a wide variety of shapes, and even though many of them are ellipsoidal (Stoddart, 1965), others are quite irregular. Atafu Atoll in the Tokelau Islands, for example, is triangular. Rose and Nukufetau atolls are square. South Minerva (Tonga) forms a figure eight. There are those that resemble a bonnet (Arno, Marshall Islands) or a spindle (Barque-Canada, South China Sea). With some imagination it is possible to see some that resemble a comma (Xuande, South China Sea), an elf's shoe (Hao, Tuamotu group), a planula larva (Parece Vela), and even a shark (Karang Kaledupa, Indonesia). In addition there are atolls with lagoons that are only partly enclosed due to submergence of part of the rim (Glorioso, western Indian Ocean), those with lagoons that display altered salinity or oxygen levels (Palmyra, Line Islands), and some that are nearly dry (Starbuck, Line Islands) or largely filled with mud and guano (McKean, Phoenix Islands).

While Appendix A is widely inclusive, it excludes reefs without lagoons and platforms with flat islands that Bryan (1953) called "pancakes," although they are noted after each geographic section. The term "table reef" is often applied to such structures. They are small, flat-topped, isolated reef platforms that rise from the deep ocean to the surface or near the surface and are covered at high tide (Tayama, 1935). Cloud (1952) modified Tayama's definition to include lagoonless oceanic platforms that develop islands. There may be a single table reef island (e.g., St. Pierre in the Seychelles Islands, Indian Ocean) or two (e.g., Poivre in the Amirante Islands, western Indian Ocean), or even a chain of them (e.g., Makin in Kiribati; Woodroffe, 2008). Filling the lagoon with sediment is a common mode of producing islands with a fringing reef from an atoll predecessor, as has occurred on some of the Tuamotu islands and is now occurring on others as described below. Guozhong (1998) used the term "table-like atolls" to bridge the gap between small, closed atolls and submerged table-like platforms in the South China Sea. I included the table-like forms with cautionary notes, although I did not include the eight table reefs he presented in his compilation of 70 atolls, nor did I include structures that are better described as submerged banks. These details are enumerated in Table A.6 and its accompanying descriptions of the South China Sea.

\section{A Definition of “Atoll Reef”}

Bryan (1953) included in his list atolls whose sole emergent attribute was a cluster of rocks exposed at high tide and excluded those that were even slightly below the surface. I specify both types, those near the surface or within a few meters of it at low tide, as "atoll reefs," as prescribed by Maragos and Williams (2011). These reefs are shallow enough to induce surface-breaking activity on the reef crest and flats (e.g., Gischler, 2016), and they possess a well-defined rim and lagoon, often fringed with a sand apron when viewed by satellite (e.g., Figure 2d). Atolls with rims that lack such distinct zonation in satellite imagery (e.g., Figure 2e) are not included in Appendix A. Based on Adolphus, Blenheim, Île Desroches and Kingman reefs, whose rim depths are known and appear to fit this description, the satellite-view limit of an atoll reef is probably closer to $10 \mathrm{~m}$ than it is to $25 \mathrm{~m}$, the minimum depth for a drowned atoll (Abby and Webster, 2011, and details below). Therefore a depth of $10 \mathrm{~m}$ or less is the approximate limit for atoll reefs listed in Appendix A, although it is recognized that some atolls with rims lying 10-25 m below the surface may exhibit vigorous coral growth in favorable locations. Atoll reefs may develop islands, but they are typically a small proportion of the rim area. For the purposes of classification, I set the limit of island development for this category of atolls at $<5 \%$ of the rim area. Rim measurements were estimated using Google Earth Pro by drawing a perimeter around the reef flat and subtracting the lagoon area less the apron. Island areas were determined individually, summed, and expressed as a percentage of the rim. I calculated island areas selectively, focusing on those atolls where, by my estimate, they constituted $10 \%$ or less of the rim area. For area calculations in Landsat I used ImageJ, and in one instance (Cato Reef, Coral Sea) where I could find no photographic record I used the same method to calculate island area from the chart description. 


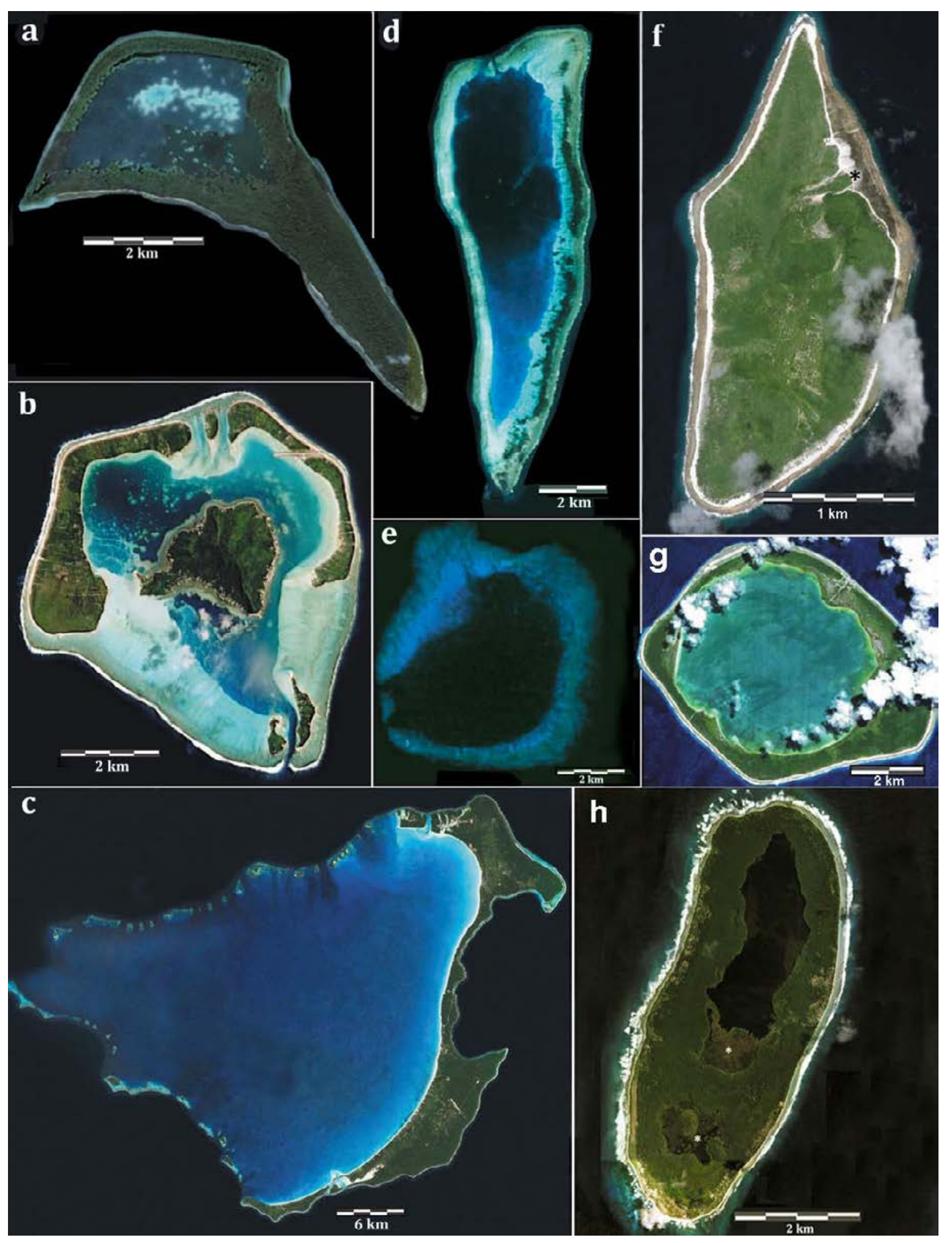

Figure 2. Variations in atoll morphology. (a) Kakaban, an uplifted atoll east of Borneo; lagoon is $60 \mathrm{~m}$ above sea level, but is euhaline due to tidal exchange. (b) Maupiti, an almost-atoll, Tuamotu Archipelago French Polynesia; lagoon depth to $25 \mathrm{~m}$; volcanic island to $>300 \mathrm{~m}$ above sea level; Onoiau Pass at SE is a $10 \mathrm{~m}$ deep ava (Rankey et al., 2011). (c) Ouvéa, New Caledonia, an atoll partially uplifted to $46 \mathrm{~m}$ on SE side (right); atoll lagoon otherwise open. (d) East London (Yinging East, South China Sea), an atoll reef rising from $\sim 1400 \mathrm{~m}$ to within a few meters of the surface; clearly defined rim, no islands; wave breaks at right on reef crest; dark margin at right is a possible lagoon slope back reef, and a sand apron is clearly developed; lagoon $14 \mathrm{~m}$ deep "with many coral heads" (Hancox and Prescott, 1995). (e) Adolphus, a submerged atoll $\left(16.2915^{\circ} \mathrm{S}, 179.3333^{\circ} \mathrm{W}\right)$ in the Ringgold group of Fiji; up to $>7 \mathrm{~m}$ deep (Agassiz, 1899); rim poorly defined in Landsat imagery. (f) Tikei, a table reef island formed from an atoll with a sedimentfilled lagoon, Tuamotu group, French Polynesia; island elevation 10-12 m; note filled channel (*) still visible, upper right. (g) Niau, a closed atoll in the Tuamotu group. The shallow lagoon owes its unusual color to green macroalgae and cyanobacterial mats that dominate the bottom. (h) Teraina, Line Islands; Holocene emergence has isolated and diminished the lagoon, now freshwater with two nearby peat bogs $(*)$ representing lagoon remnants. Figures (a), (d), (f), (g) rotated to fit page format; figures (b-e) LandsatLook Natural Color imagery; figures (a), (f), (h) courtesy of DigitalGlobe/TerraMetrics; figure (g) European Space Agency. 


\section{Atoll Names and Locations}

The spelling of many atolls has changed over the last six-plus decades, and there is additional variability depending on the country that lays claim to them. Gouzhong (1998), for example, uses Chinese names that are often not shared by neighboring nations or by commonly available databases. Alternative names used on standard charts are provided. In other cases, names have changed from European to Polynesian or Divehi (Maldivian), and, to make it more difficult, there are numerous variations in the phonetic spelling of those names. Wherever possible I used the designations in charts provided by Spalding et al. (2001). However, some atolls were unlabeled or presented spelling discrepancies, in which case I used names on NGA charts or Sailing Directions, specified in the footnotes within each island group. Some atolls have duplicate names. For example, two are named Pukapuka, including one in the Cook Islands and another in the Society Islands, although the latter is often distinguished by a hyphen (Puka-Puka). There is also a Manuae Atoll in the Cook Islands and another in the Tuamotu Archipelago.

\section{GIS}

The coordinates for each location typically were based on the lagoon or platform center using Google Earth (WGS84), or Landsat (WRS) when Google Earth imagery was not available. These data were converted to shapefiles (.shp) to produce static maps with named dots to represent each atoll. The dots were color coded to depict the type of atoll, including atoll reefs, those with open and closed lagoons, and closed atolls with altered lagoon salinities. These are presented in the appendix. In addition, an atollspecific compendium of satellite photographs is presented as a supplement to this work using the maps published here, but in interactive form using ArcGIS Online. This record can be accessed through http://maps.fiu.edu/gis/goldberg/atolls. Imagery was taken primarily from Google Earth, but Landsat or NASA imagery was substituted where necessary. In one case I resorted to aerial photography (Nantong Atoll, South China Sea), and in two others I could not find any imagery. I was also unable to confirm the appearance of several nominal atolls by any means other than chart notation, including Carondelet Reef (Phoenix Islands), Whirlwind and Ottilien Reefs (Admiralty Islands; Bryan, 1953), Lyra Reef (Papua New Guinea; Spalding, 2001:228), Moses Reef, Récif Lancaster or Récif President Thiers (Austral Archipelago, French Polynesia; Spalding, 2001:390), among others, and these were not included in maps or tables presented in the appendixes.

\section{RESULTS AND DISCUSSION}

\section{Lagoon Variation: An Abbreviated Overview of the Atoll Family}

Lagoon circulation is dependent on a number of factors, including tides and storms, passages through or across the rim, and other features such as island height and distribution around the atoll. Shallow rim passes (hoa in Polynesian) may vary from tens to hundreds of meters wide across the reef flat, but despite being $\leq 1 \mathrm{~m}$ deep, they facilitate exchange of lagoon and ocean water through breaks in island continuity (reviewed by Stoddart and Fosberg, 1994). There are 78 atolls with lagoons in French Polynesia (Salvat, 2009), although there are also four former atolls with filled lagoons (Akiaki, Nukutavake, Tikei and Tepoto Nord) and one (Makatea) that is uplifted. These are not included in the totals (see Table A.10). The 78 with lagoons include 71 in the Tuamotu group, 5 in the Society group, 1 in the Austral Islands and 1 in the Gambier group. On most of them, hoa are numerous (e.g., Figure 3a) and are sufficient to exchange water with the tides on a daily basis, even among lagoons that are closed (see below). However, on several of these atolls where hoa are poorly developed, there is a more limited exchange. For example, eight atolls in French Polynesia have only two shallow hoa and sixteen have only one. These may become functional only during swell conditions, and in some cases water renewal may depend almost entirely on cyclonic events (Salvat, 2009). Salinities may thereby become altered compared with oceanic water. 


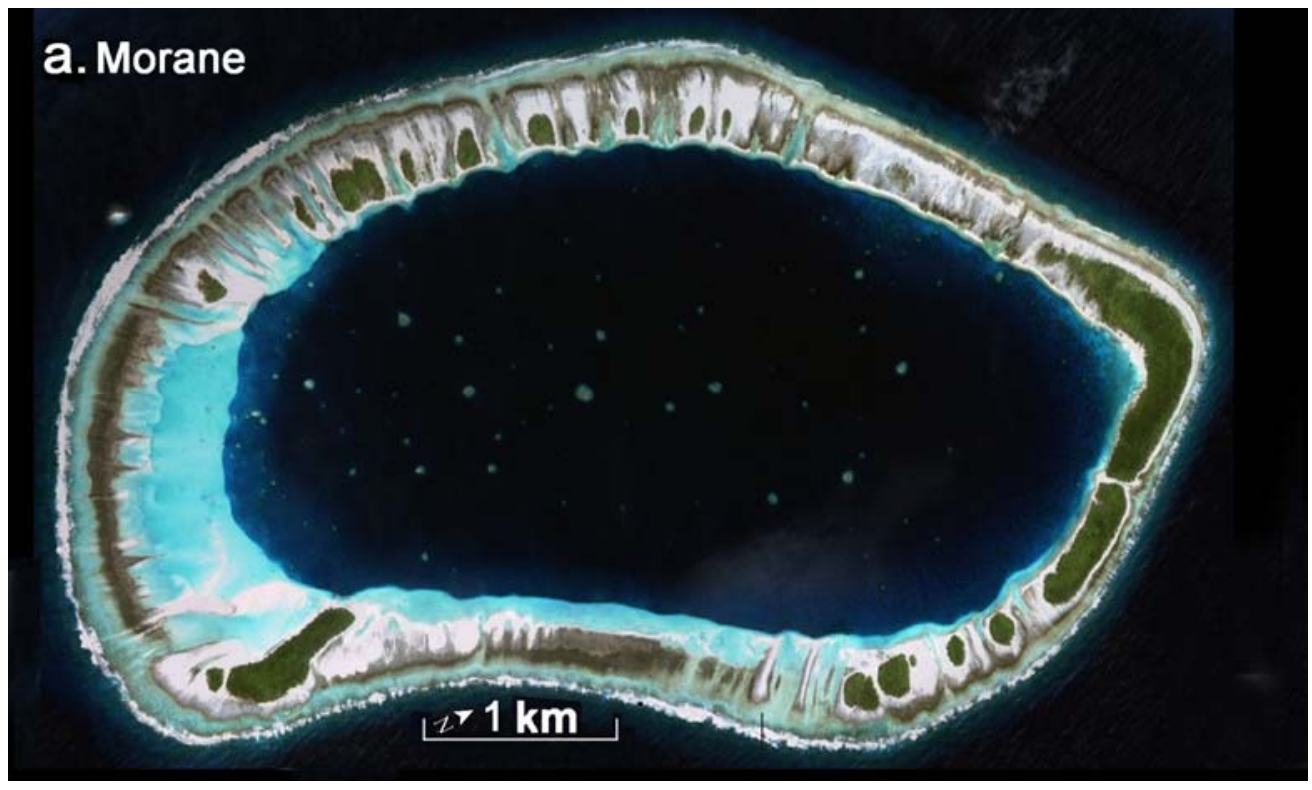

Figure 3. Comparison of open and closed atoll lagoons. (a) Morane, in the southern Tuamotu group. The rim is continuous with numerous motu and well developed hoa on most of the perimeter; there are no breaks in the rim. This lagoon is closed but maintains a marine character. (b) Haraiki, Tuamotu Archipelago, a small atoll bound by islands at north. The rim is well developed around most of the lagoon with hoa along the western side. However, a channel that breaches the rim is clearly visible at the south. (c) Taiaro, also in the Tuamotu group, is rimmed primarily by islands. There are few hoa on the east and south. The development of the rim restricts exchange, and in this case produces a hypersaline lagoon. Courtesy of DigitalGlobe/TerraMetrics.
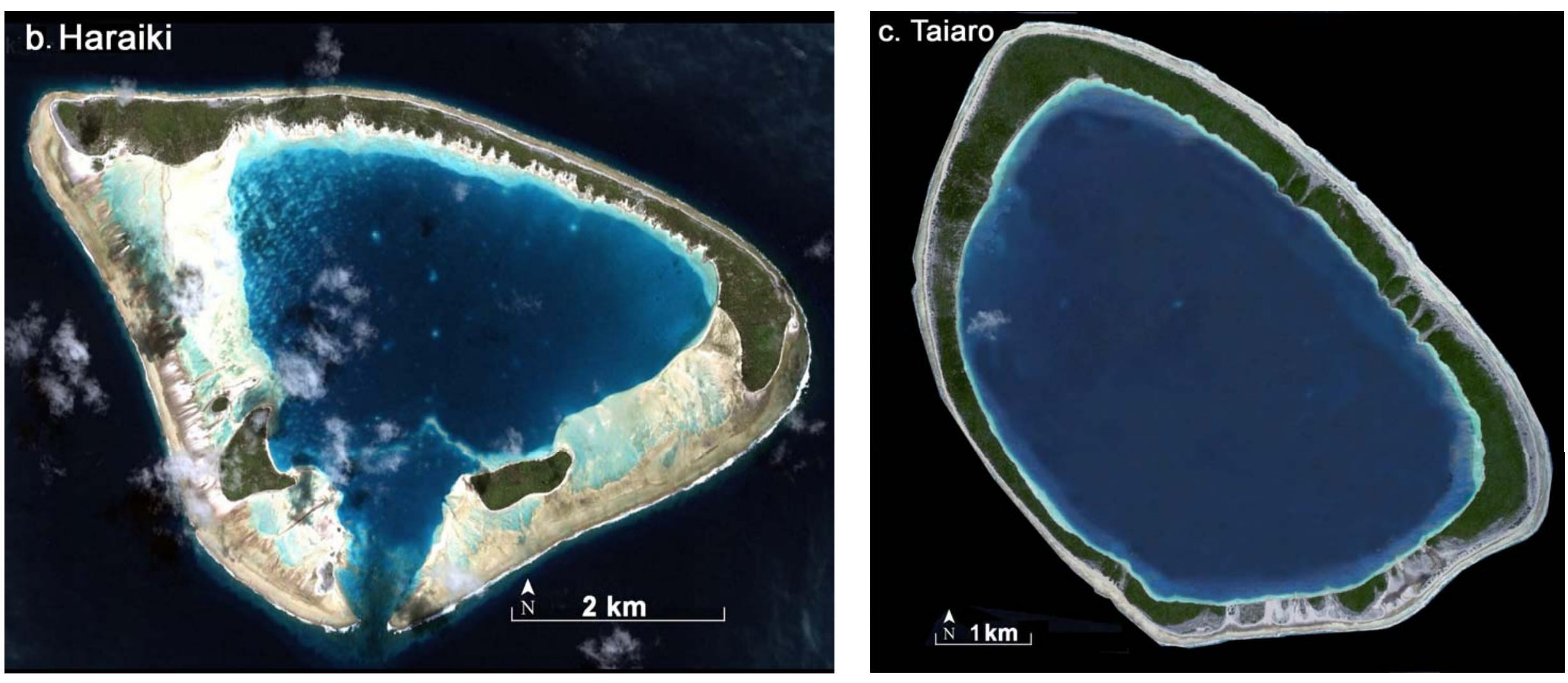
However, the absence of hoa is not always an impediment to lagoon circulation. On the atolls of Manahiki and Rakahanga in the Cook group, for example, the windward side is a wall of islands, but large waves force water over the rim (Callaghan et al., 2006). Waves may also break on the reef flats and be driven across (e.g., Majuro in the Marshall Islands; Kraines et al., 2001).

In other cases, factors in lagoon circulation are more complex and include combinations of surf and tide that impel waters over the rim, as well as into and through deeper channels, called ava in Polynesian (Woodroffe, 2011), that cut through the rim (e.g., on Enewetak; Atkinson et al., 1981). An example of hoa and ava entrances to the lagoon is shown in Figure 3b. Likewise, if the lagoon's fetch is large enough, and if the geometry of the bottom facilitates it, wind-driven waves inside the lagoon may be an additional and even a dominant circulatory force (e.g., Andréfouët et al., 2001; Montaggioni et al., 2015). There are even a few instances in which lagoons appear to be quite open but nonetheless develop a degree of hypersalinity, as on Glover's, Lighthouse and Turneffe reefs of Belize (Table B.1; Hauser et al., 2007). The main lagoon of Turneffe is $8 \mathrm{~m}$ deep and exhibits restricted circulation due to mangrove development (Gischler, 2003). The other two Belizean lagoons are somewhat deeper $(<18 \mathrm{~m})$, but the factors responsible for elevated salinity in them have yet to be clarified.

In general, there is a positive relationship between atoll area and maximum lagoon depth (Purdy and Winterer, 2001; 2006), although lagoon circulation and its renewal time is complicated by features of the rim and local hydrodynamic conditions. On large, relatively open atolls such as Enewetak (area $>1000$ $\mathrm{km}^{2}$, Marshall Islands) where the lagoon extends to a depth of more than $60 \mathrm{~m}$, renewal time may require 30-120 days (Atkinson et al., 1981), whereas on 35 m deep Rangiroa (Tuamotu Islands, area $>1700 \mathrm{~km}^{2}$ ), estimates suggest that lagoon circulation may require 155 days (Pagès and Andréfouët, 2001). The renewal of water in deep lagoon systems appears to depend on the presence of deep passages through the rim (e.g., Atkinson et al., 1981; Kench, 1998; Suzuki and Kawahata, 1999). On small atolls where lagoons may be shallow and open, circulation may be very rapid (Andréfouët et al., 2001). However, on Nukuoro (Caroline group), where the rim encloses an area of only $37 \mathrm{~km}^{2}$, the lagoon reaches a depth of $99 \mathrm{~m}$. Likewise on Ngatik in the Caroline group, the rim surrounds an area of $55 \mathrm{~km}^{2}$ (with the exception of a single, narrow, $11 \mathrm{~m}$ deep channel), but the lagoon is $159 \mathrm{~m}$ deep (Purdy and Winterer, 2001). Little is known about the circulation mechanics or renewal times of these unusual systems.

\section{Tidally Dominated, Semi-Closed Atoll Lagoons}

On some atolls a single passage through the rim allows the tides to jet through the lagoon, as on Ahe, French Polynesia (Dumas et al., 2012), among others, suggesting that in these locations tidal effects can be the primary mode of lagoon circulation. Such atolls can be referred to as "semi-closed." Aldabra (southwestern Indian Ocean) represents a more visible case of tidal influence. This atoll became stranded at $8 \mathrm{~m}$ above MSL as rising Holocene sea levels failed to reach the rim produced in the higher sea levels of the Pleistocene (Braithwaite et al., 1973). The lagoon is now shallow and renewal of its water is dependent on the state of the tides. At low-water spring tides, much of the lagoon floor is exposed, except for its depressions. However, a rising spring tide may extend to greater than $3 \mathrm{~m}$ above MSL and enter through restricted channels as it returns ocean water to the lagoon (Stoddart et al., 1971; Pugh, 1979). Much smaller Astove Island is likewise emergent; its $0.5 \mathrm{~m}$ deep lagoon is all but closed, save a single channel, and it functions in much the same manner (Bayne et al., 1970). Such tidally dependent atolls are included in Appendix A.

\section{Closed Lagoons}

Some atolls may develop rims that are continuous and form closed lagoons (e.g., Salvat, 1985). Indeed, there are 104 such atolls listed in Appendix A and in the appended maps. The distinction between open and closed systems is demonstrated in Figure 3. However, there are some variations, including atolls with shallow channels that are deeper than hoa (e.g., narrow 4-5 m deep passes on Lae and Utrik atolls, Marshall Islands) but are navigable only given the draft of the vessel and the skill of the navigator. 
Similarly, atolls such as Malum (Bismarck Archipelago) and Olimarao (Caroline Islands), among others, may have navigable passes, but their depths are not described on standard charts. There are also many with artificial channels, including some that allow the passage of large vessels but provide little effective oceanic exchange to the lagoon (e.g., Palmyra Atoll). Kiritimati Atoll (Line Islands) combines a large, open lagoon with numerous inner lagoons that are closed as described below. Although most closed atolls in the Tuamotu group are not totally isolated from the ocean, there are a few that exhibit brackish water or hypersalinity (Figure 3c; Table B.1). This occurs as a function of overwash by storms and cyclones on one hand counterbalanced on the other by the relative amounts of rainfall and evaporation (Pirazzoli et al., 1988). Nonetheless, most retain a distinctly marine fauna in the lagoon, although some are dominated by just a few species of bivalve mollusks and holothurians (Adjeroud et al., 2000; Salvat, 2009). Because of dependence on wind and wave-driven mixing, such closed atolls are more susceptible to mass mortalities than open systems, likely triggered by several weeks of unusually calm weather conditions (Andréfouët et al., 2015). This may contribute to the depauperate condition of their lagoons.

In other instances, closed and apparently isolated lagoons may maintain some degree of tidal connection by means of channels and fissures in the reef platform. This may be the case for Niutao and Nanumanga (Tuvalu), where salt-water flushing at high tide maintains the marine character of their lagoons even as high levels of detritus, among other factors, may facilitate the development of extensive mangrove forests around them (Woodroffe, 1987; Wester et al., 1992). However, these lagoons have also been reported as brackish (Krüger, 2008), perhaps due to heavy rainfall. By contrast, Indonesia's Kakaban lagoon is tidally flushed and is clearly marine even though it is $60 \mathrm{~m}$ above sea level, as described below. As a distinctly different system, McKean Island's 26 ha lagoon (Phoenix Islands) is nearly filled with guano and carbonate mud, but it is covered and uncovered with seawater depending on the state of the tide (Dana, 1979).

Some atolls in the central Pacific have entered a late stage of development in which subsidence is now irregular or has ceased entirely. As a result, when relative sea levels fell by perhaps 1 to $>2$ meters during the late Holocene (e.g., Woodroffe et al., 1990; Woodroffe and McLean, 1998; Dickinson, 2004), a number of lagoons became isolated and emergent. Starbuck Island's lagoon (Line Islands) is now hypersaline, although it tends to dry except for its deeper pools (Keating, 1992). Laysan Island's lagoon (Hawaii) is also hypersaline (Caspers, 1981; Athens et al., 2007). Similar reports of high salinity have been made for lagoons on Enderbury and Manra in the Phoenix Islands (Wiens, 1962), although they also have been reported as brackish (Obura, 2011). Other small, shallow and isolated lagoons in the Phoenix Islands (Rawaki, Birnie, and others) may be subject to salinity swings, perhaps accounting for similar reports of brackish water by some (Pierce et al., 2006; Obura, 2011) and hypersalinity by others (Thorson et al., 2008). Kiritimati (Line Islands, Kiribati) still retains the marine character of its main lagoon, which is open, occupies a third of the interior, and is influenced by tidal exchange. However, the rest of it is subdivided into hundreds of isolated channels and saline ponds by karstified paleoreef ridges. The ponds that are farthest from the main lagoon tend to be hypersaline, some of them >150\%o (Saenger et al., 2006). By contrast, the salinity of the $10 \mathrm{~m}$ deep lagoon on Olosega (Swains Island, American Samoa) is 4-5\%o despite being elevated only 3-4 m above sea level (Van Tilberg et al., 2013). Pulusuk’s lagoon (Caroline Islands) is 1-4 m deep and becomes fresh water with sufficient rainfall; otherwise it is oligohaline (Wester et al., 1992).

Teraina (northern Line Islands, central Pacific) is quite unusual. Most of the island has become emergent and is now 3-5 m above sea level. However, at its center is a freshwater lake (Lake Washington) that is $7 \times 2.5 \mathrm{~km}$ across and about $10 \mathrm{~m}$ deep (Figure $2 \mathrm{~h}$ ). Its limnetic character is maintained by locally high rainfall, typically $2900 \mathrm{~mm}$ annually, although that figure can double in El Niño years. Interestingly, the lake bottom contains fossil Acropora and Tridacna in place, indicating a once-active lagoon reef. There are in addition two peat bogs, one adjacent to the lake and another at the western end of the island, that formed during the last 1150 and 1060 years, respectively (Wester et al., 1992; Saenger et al., 2006). I have noted and included islands with closed lagoons containing brackish, hypersaline, and other anomalous features in Appendix A, as well as in the appended maps, and I list them separately in Table B.1. 
Clipperton Island, isolated in the eastern Pacific, is only 2-5 m above sea level, similar to Teraina. However, its lagoon closed when the only channel to the ocean was cut off by sedimentation some time during the 1850s, whereupon the lagoon became stratified. The upper $10 \mathrm{~m}$ is now oligohaline ( 5\%o), and while it is euhaline below that, the deeper lagoon $(\mathrm{dmax}=37 \mathrm{~m})$ is totally anoxic with high levels of $\mathrm{H}_{2} \mathrm{~S}$. This meromictic system is unique among atolls (Charpy et al., 2010). However, Clipperton is an almost-atoll (near atoll), an annular reef with vestiges of volcanic material that will disappear with continued subsidence (Davis, 1928; Stoddart, 1975; Scott and Rotondo, 1983). Others include Aitutaki (Cook Islands), Hermit Islands (Papua New Guinea), Exploring Isles (Fiji) and Maupiti (Society Islands, Figure 2b). I included examples of almost-atolls in each geographic section of Appendix A, although I did not list them comprehensively and I did not count them as atolls.

The islands on Akiaki, Nukutavake, Tikei and Tepoto Nord (Tuamotu group, Figure 2f) have developed high dunes and these have served as a natural conduit for sediments blown into the lagoon by storms. These former atoll lagoons are now filled (Rougerie et al., 1997) and have been converted to table islands and reefs. They are noted in Appendix A but are not included in the totals in Table A.21. The same process of lagoon occlusion is now occurring on Tatakoto Atoll in the Tuamotu Islands (Pirazzoli et al., 1988), as it is on Nui and Vaitupu atolls in Tuvalu (McLean and Hosking, 1991) and Chetlat and Kiltan in the Lakshadweep Islands (Wagle and Kunte, 1999), among many others. Thus storms and cyclones may play a common and critical role in the life history of atoll lagoons, especially those that are small and susceptible to being filled (Woodroffe, 2008; Salvat, 2009). Atolls with reduced but extant lagoons are included in Appendix A.

\section{Uplifted Atoll Lagoons}

Flex and arch motions of lithospheric plates or proximity to subduction zones in tectonically active regions may elevate atolls (McNutt and Menard, 1978; Neall and Trewick, 2008). Ouvéa in New Caledonia (Figure 2c) has grown over a partially uplifted paleoatoll and is now $46 \mathrm{~m}$ above sea level on the southeastern side. However, the opposite side of the rim is close to sea level due to tilting that took place at some time during the last interglacial to mid-Holocene (Chevalier, 1973; Dubois et al., 1974). Maré and Lifou, its island neighbors to the south, are fully emergent paleoatolls. All three have been uplifted by the forebulge of the nearby New Hebrides Trench (Dickinson, 2013). Niau Atoll (Figure 2g) in the Tuamotu group is now $7 \mathrm{~m}$ above sea level, in part due to modest tectonic uplift associated with the proximity of the Society Islands hotspot (Pirazzoli, 1994). In contrast with most of the other closed Tuamotu atolls, substitution of Niau's lagoon water is driven primarily by atmospheric exchange and the porosity of the carbonate (e.g., Andréfouët et al., 2001). As a result the salinity of its shallow lagoon ( 2 m deep; Tröndlé and Salvat, 2010) is reduced compared with open-ocean seawater, although it is still a marine system with its benthos dominated by macroalgae (e.g., Caulerpa) and thick cyanobacterial mats (Jehl and Rougerie, 1995; Rougerie et al., 1997). Nunn (1994) lists some other atolls in French Polynesia that appear to have been uplifted or partially uplifted by less than a meter, including Hao, Hereheretue, Maupihaa, Nukutipipi, Tureia, Vahitahi and Temoe.

In other cases the entire atoll has been uplifted, sometimes forming spectacular cliffs due to erosion of the once-submerged carbonate. Rennell Island in the Solomon Archipelago is the most extensive of these and is up to $200 \mathrm{~m}$ above present sea level. Makatea in French Polynesia (113 m) and Niue $(65 \mathrm{~m})$ are other well-known examples of uplifted atolls (Guilcher, 1988). Rennell retains a large, low-salinity, brackish-water lagoon (Lake Tegano) at its eastern end (<4\%; Wolff, 1970), whereas the lagoons of Makatea and Niue have been replaced by terrestrial vegetation in what is now a large central depression (Montaggioni and Camoin, 1997; Terry and Nunn, 2003). These are often not included as atolls and indeed Bryan (1953) left them off his list; they are also not included here. However, consider Kakaban, an atoll east of Borneo (Sulawesi Sea, Indonesia) whose rim is $60 \mathrm{~m}$ above sea level (Figure 2a). While the lagoon is shallow $(8.5 \mathrm{~m})$ and is, not surprisingly, closed, it is euhaline, likely due to tidal communication through underground fissures and caves. As a result, the benthic community is dominated by meadows of Halimeda (Tomascik and Mah, 1994). Bryan (1953) did not include this unusual atoll, but it is listed in 
Table A.8. Thus, there is a considerable diversity of atoll structure and dynamics, with multiple governing forces that often make it difficult to draw a line of exclusion based on the area, depth, salinity, elevation, and other characteristics of the lagoon.

\section{Atoll Reefs}

Some atolls that occur on subsiding volcanic platforms have failed to thrive. The term most often applied is that of a "submerged reef" or its terminological equivalents, including "drowned atoll" or "give-up atoll." Such reefs are defined as those occurring in depths from $25 \mathrm{~m}$ to $40 \mathrm{~m}$ and deeper, whose growth is or was insufficient to sustain them in the face of rising sea levels, high subsidence rates, unfavorable water conditions, or all of these (e.g., Scott and Rotondo, 1983; Beaman et al., 2008; Abby and Webster, 2011). Coral reefs of any type at those depths may be affected by reduced light, if not temperature, and are likely to be in a marginal position with respect to calcification and growth (e.g., Kleypas et al., 1999; Grigg, 2008). However, there is a tendency to apply this term to atolls without islands whose reef surfaces are just beneath or perhaps a few meters below the tides, where their growth is unlikely to be compromised. Wiens (1962) appreciated the distinction between the drowned condition and instances in which an atoll's rim and lagoon were covered at present sea level or at high tides. Bryan (1953) referred to these as "sunken atolls," but he did not list them. Chevalier (1973) called them "half atolls." Scott and Rotondo (1983) used the term "inundated atolls," as long as they projected some portion of the reef above sea level at low tide, and Nunn (1994) referred to atolls without islands as "ring reefs." However, atolls represent a continuum of rim structure, including some that are tilted and partially submerged, and others whose rim is largely or completely submerged in a few meters of water. Thus, a term that describes the submerged but not drowned condition of some atolls would be very useful. Sheppard et al. make Blenheim Reef (Chagos Archipelago, Indian Ocean) a case in point by stating that it is "a typical atoll in most respects except for its present lack of islands, and indeed its wave-resistant algal ridges are the best developed in the Archipelago and possibly the entire ocean" (2013:225). Their table, however, lists Blenheim as "submerged," which would be a perfectly good description were it not for its current and sometimes confusing usage. Recalling all of its atoll-like bona fides, it is noteworthy that more than half of Blenheim Reef is perched at a depth of $5 \mathrm{~m}$ or less (Sheppard, 2000).

There are a great many well-formed atolls that are at or near the surface in addition to Blenheim. In Fiji, for example, most atolls are subsurface and are mixed together with a large number of nearby barrier reefs and almost-atolls. This arises from a complex regional geology that involves rotation of the Fijian platform and has resulted in subsidence of some islands while others in the same vicinity have become uplifted (Nunn, 1987; Nunn et al., 2002). A few Fijian atolls do form islands or sand cays, but they compose little of the rim. Thus the transition between no islands and a small number relative to the rim becomes a necessary accommodation when the full spectrum of atoll morphologies is considered. Therefore I modified Maragos and Williams's (2011) definition of “atoll reef” to accommodate up to 5\% of the rim above present sea level (see "Methods" above). By this standard, 24 of 25 Fijian atolls fall into this category. It is worth noting that the atolls of Fiji are so poorly known that the best reference for them is Agassiz (1899), which I consulted along with Davis (1928), Spalding (2001), and Landsat/Google Earth imagery to compose the list for that area.

With the exception of the notable work by Tomascik et al. (1997), Indonesian reefs are also poorly described. In this large and geologically complex region, 25 of the 40 atolls ( $>62 \%$; Table A.8) are atoll reefs with clearly defined rims and lagoons in satellite imagery. The Banda Sea in particular contains a great many of these rising from $\sim 400-4000 \mathrm{~m}$, and few have been examined. Likewise, 49 of 52 atolls (> 94\%) identified by Guozhong (1998) in the South China Sea are essentially or completely subtidal. Indeed, of all 439 atolls listed in Appendix A, 171 (39\%) are atoll reefs. These are further depicted in the appended maps.

Five South China Sea atoll reefs, as well as parts of other reef systems, have been heavily dredged and filled recently to create artificial islands for military purposes, as well as for bases from which natural resources are now being exploited (Morton and Blackmore, 2001; Larson, 2015). Indeed, in some cases 
such as Fiery Cross, these atolls have been modified nearly beyond recognition (see supplementary material). Although they are not atoll reefs, Johnston and Palmyra atolls, among a long list of others in the Pacific, were similarly adapted and highly modified for military use during World War II (Lobel and Lobel, 2008). These anthropogenically modified atolls are included in Table A.19.

\section{Shelf Atolls and True Atolls}

Lastly, while all atolls (and other reefs) are molded by the configuration of their antecedent platforms, coral reef growth, sea level change, and their wind and wave climate regime, there are two categories. Classic Darwinian forms occur on deep-water, subsiding volcanic platforms, and to some these are the only atolls. However, for this overview I included those that grew as coral-capped seamounts rather than on subsiding volcanic platforms, as Middleton and Elizabeth reefs off southeast Australia appear to be (Woodroffe et al., 2004). More of these seamount platforms form part of the Lord Howe Chain, whose peaks extend to the reef-capped Chesterfield and Bellona atolls west of New Caledonia (Pelletier, 2007; Andréfouët et al., 2009). Likewise, Cato, Frederick, Kenn, Mellish and Wreck reefs are atoll-like reefs atop Australia's Tasmantid Seamounts (Ceccarelli, 2011). These and others like them are included in the list of atolls in Table A.12 and in the appended maps.

Davis (1928) called all reefs lying back from the edge of a continental shelf "bank reefs," and if they had islands they were "bank atolls." Indeed, atolls with largely submerged rims were often relegated to the status of banks (Vecsei, 2000). However, atoll-like structures that have grown on high spots of continental shelves, on their edges or their slopes, are now widely recognized as another type of atoll (e.g., Stoddart, 1962; Ladd, 1977; Tomascik et al., 1997; Gouzhong, 1998; Woodroffe, 2011), even if they may have had different origins. Caribbean atolls in particular occur on a variety of platforms, which Geister (1983) has categorized as shelf, shelf edge, bank atoll, incomplete bank, lagoon atolls, and oceanic atolls. He considered that there are 15 such structures in the Caribbean region, fewer than the 26 listed by Bryan (1953), but more than the conservative 10 contemplated by Milliman (1973), whose list is adopted here. There is a distinct minority of atolls listed in Appendix A that have developed on continental shelves, although there are many more on shelf edges and slopes that display a rim and lagoon structure.

As a rule, I avoided rendering my own verdict of what belongs in Appendix A, relying on the literature and on precedent, as should be clear from the text. In some cases I was unable to confirm atoll morphology by chart or satellite view, and those were left off the list. In a few instances I added atolls, including an unnamed pair in the Banda Sea and three in the Santa Cruz Islands. These represent areas among many others where there is still much work to be done.

\section{ACKNOWLEDGMENTS}

I thank Jim Maragos (Hawaii), Bernard Salvat (Univ. Perpignan), Eberhard Gischler (Goethe Univ., Frankfurt), and two anonymous reviewers for their reviews and valuable comments on the manuscript. I am also grateful to Jennifer Fu, Daniel Gann and Matthew Toro at Florida International University's GIS Center for sharing their expertise in mapping that added a significant dimension to this work. This synopsis is dedicated to the memory of Edwin H. Bryan, Jr. and the contribution of his checklist to atoll research. 


\section{Appendix A: Annotated Lists of 439 Atolls}

The coordinates listed below, as well as measurements of island area, are based on Google Earth Pro. When imagery was not available from Google Earth, coordinates were taken from LandsatLook. Coordinates from both sources were taken at the approximate lagoon or platform center. The atolls listed here have been incorporated into static maps in Appendix C, Figures C.1-C.6. In addition, supplemental material available from http://maps.fiu.edu/gis/goldberg/atolls provides access to an interactive map in which satellite imagery is provided for nearly all of the 439 atolls presented. Imagery is primarily from Google Earth and Landsat but is supplemented where necessary by NASA archives and in one case by aerial photography. I was unable to locate imagery for two atolls.

The tables that follow are individually numbered and organized by oceanic region and atoll group, as follows:

Table A.1 - Atlantic Ocean

Table A.2 - Western Indian Ocean

Table A.3 - Eastern Indian Ocean

Table A.4 - Lakshadweep

Table A.5 - The Maldives

Table A.6 - South China Sea

Table A.7 - The Philippines

Table A.8 - Indonesia

Table A.9 - Papua New Guinea to Vanuatu

Table A.10 - Fiji

Table A.11 - New Caledonia

Table A.12 - Australia

Table A.13 - The Caroline Islands

Table A.14 - Isolated Pacific

Table A.15 - The Marshall Islands

Table A.16 - The Gilbert Islands

Table A.17 - Tuvalu

Table A.18 - Hawaii

Table A.19 - Central Pacific

Table A.20 - Cook Islands

Table A.21 - French Polynesia

Table A.22 - Eastern Pacific

For ease of use and reference, individual atolls are assigned sequential numbers. Explanatory text making reference to specific atolls makes note of the atoll's number in the tables. There are 171 atoll reefs indicated throughout all tables by an asterisk $(*)$. Atoll reefs are those with less than $5 \%$ of their rim developed as islands or cays (measured using Google Earth Pro), or atolls completely immersed at low tide, but with visible and prominent rim and lagoon. In addition there are 104 atolls with closed lagoons indicated in the tables by a dagger $(\dagger)$. Closed lagoons are those with rims that lack a navigable channel or passage to the lagoon and include those that are completely enclosed by island development, those with hoa, or those with open reef flats that represent an unbroken rim. Atoll reefs were not evaluated as open or closed systems.

\section{ATLANTIC OCEAN 11 Atolls}

Bryan lists 26 atolls for the greater Caribbean, and Geister (1983) lists 15, but a more probable estimate is 10 (Milliman, 1967, 1969, 1973). Bryan's list for this region is reduced accordingly (Table A.1). Most Atlantic atolls (82\%) are atoll reefs. Of the two with islands, there are sand cays on 
Lighthouse Reef (no. 5) that account for just over 5\% of its rim area. Less than $1 \%$ of Turneffe's (no. 4) $577 \mathrm{~km}^{2}$ surface is marked by sand cays, but I estimate that $21-25 \%$ of its interior is constituted by mangrove islands.

Table A.1. Atolls of the Atlantic Ocean. An asterisk (*) indicates an atoll reef.

\begin{tabular}{rlrc} 
Atoll No. & Atoll Name & Latitude & Longitude \\
\hline \multicolumn{4}{c}{ Bahamas/Caribbean } \\
1 & Hogsty Reef* & $21.6880^{\circ} \mathrm{N}$ & $73.8136^{\circ} \mathrm{W}$ \\
2 & Arricife Alacrán* & $22.4754^{\circ} \mathrm{N}$ & $89.6937^{\circ} \mathrm{W}$ \\
3 & Chinchorro Bank* $^{*}$ & $18.5922^{\circ} \mathrm{N}$ & $87.3480^{\circ} \mathrm{W}$ \\
4 & Turneffe Reef $^{\circ}$ & $17.3300^{\circ} \mathrm{N}$ & $87.8700^{\circ} \mathrm{W}$ \\
5 & Lighthouse Reef $^{\circ}$ & $17.3239^{\circ} \mathrm{N}$ & $87.5389^{\circ} \mathrm{W}$ \\
6 & Glover's Reef* $^{*}$ & $16.8203^{\circ} \mathrm{N}$ & $87.7880^{\circ} \mathrm{W}$ \\
7 & Albuquerque Cays* & $12.1624^{\circ} \mathrm{N}$ & $81.8431^{\circ} \mathrm{W}$ \\
8 & Courtown Cays* $^{*}$ & $12.4140^{\circ} \mathrm{N}$ & $81.4593^{\circ} \mathrm{W}$ \\
9 & Roncador Bank* $^{*}$ & $13.5358^{\circ} \mathrm{N}$ & $80.0467^{\circ} \mathrm{W}$ \\
10 & Serrana Bank* & $14.3826^{\circ} \mathrm{N}$ & $80.2408^{\circ} \mathrm{W}$ \\
\multicolumn{4}{c}{ South Atlantic $^{\circ}$} \\
11 & Atol das Rocas*a & $3.8629^{\circ} \mathrm{N}$ & $33.8033^{\circ} \mathrm{W}$ \\
\hline
\end{tabular}

${ }^{\mathrm{a}}$ Gherardi and Bosence, 2005

\section{INDIAN OCEAN \\ 56 Atolls}

One atoll in the Red Sea, Sanganeb Atoll (no. 12), is tentatively included in this count. Sanganeb is referred to as an atoll (e.g., Head, 1987), but status other than atoll geomorphology is controversial (Reinicke et al., 2003) and there are others similar to it in the vicinity.

For general descriptions of western Indian Ocean reefs see Stoddart (1970). Aldabra (19) is a large emergent atoll (4.5-8 m) with lagoon open to tidal flushing (Stoddart et al., 1971). Astove (21) is an elevated atoll, tilted $4-5 \mathrm{~m}$ on the west with a closed, shallow ( $0.5 \mathrm{~m}$ deep), and tide-dependent lagoon that drains at neap and fills with spring tides (Bayne et al., 1970). Glorioso Islands and reef (22) partially enclose a shallow V-shaped lagoon that is submerged $9 \mathrm{~m}$ at its northern side (NGA chart 61300). Scott Reef (31) consists of two atolls on one platform, circular Scott Reef Central and horseshoe-shaped Scott Reef South. Mermaid Reef (32) was not listed by Bryan due to its coverage by the tides. Three are added to the list: Bassas da India (13) and Blenheim Reef (23) are shallow with rocks or cays awash on part of the rim; Île Europa (14) is elevated but retains a channel-like lagoon that is open (Quod et al., 2007). The lagoon at North Keeling (28) is partially infilled and has become diminished by rapid subsidence (Woodroffe et al., 1991).

Bryan lists 32 atolls in the Chagos Archipelago and in the western Indian Ocean, but twenty of them have not been included because they are not typical of atoll morphology and are best considered as table reefs (Stoddart, 1970, 1973, 1984; Turner and Klaus, 2005; Hamylton et al., 2012). These include 16 isolated islands or island groups-Agalega, Cargados Carajos and Coco Reef, Cerf Islands and Île Tromellin. Additional table reefs are found in the Seychelles Archipelago—Bird, Coëtivy, Denis—as well as in the Amirante Archipelago_-African Banks, Boudeuse, D’Arros, Remire (Eagle), Etoile, Île des Noeufs, Marie Louise, and Poivre (Spalding et al., 2001; Spencer et al., 2009). Satellite views indicate that Île Desroches and Platte are islands perched on atoll-like platforms that are submerged, the former to a depth of up to $18 \mathrm{~m}$ (Stoddart, 1970). Chagos Bank is also submerged; Nelson's Island on the Chagos rim is a table reef. None of these from Bryan's list are included in Tables A.2 and A.3. 
Table A.2. Atolls of the Western Indian Ocean. An asterisk (*) indicates an atoll reef. A dagger $(\dagger)$ indicates a closed lagoon.

\begin{tabular}{|c|c|c|c|}
\hline Atoll No. & Atoll Name & Latitude & Longitude \\
\hline \multicolumn{4}{|c|}{ Red Sea } \\
\hline 12 & Sanganeb* & $18.4003^{\circ} \mathrm{N}$ & $38.4901^{\circ} \mathrm{E}$ \\
\hline \multicolumn{4}{|c|}{ Mozambique Channel } \\
\hline 13 & Bassas da India* & $21.4791^{\circ} \mathrm{S}$ & $39.6827^{\circ} \mathrm{E}$ \\
\hline 14 & Île Europa & $22.3698^{\circ} \mathrm{S}$ & $40.3699^{\circ} \mathrm{E}$ \\
\hline \multicolumn{4}{|c|}{ Amirante Islands } \\
\hline 15 & St. Joseph ${ }^{\dagger}$ & $5.4306^{\circ} \mathrm{S}$ & $53.3358^{\circ} \mathrm{E}$ \\
\hline 16 & Île Alphonse & $7.0206^{\circ} \mathrm{S}$ & $52.7374^{\circ} \mathrm{E}$ \\
\hline 17 & St. François & $7.1177^{\circ} \mathrm{S}$ & $52.7490^{\circ} \mathrm{E}$ \\
\hline \multicolumn{4}{|c|}{ Seychelles Group } \\
\hline 18 & Farquhar & $10.1893^{\circ} \mathrm{S}$ & $51.1017^{\circ} \mathrm{E}$ \\
\hline 19 & Aldabra & $9.4203^{\circ} \mathrm{S}$ & $46.3411^{\circ} \mathrm{E}$ \\
\hline 20 & Cosmoledo & $9.7219^{\circ} \mathrm{S}$ & $47.5927^{\circ} \mathrm{E}$ \\
\hline 21 & Astove Island & $10.0884^{\circ} \mathrm{S}$ & $47.7457^{\circ} \mathrm{E}$ \\
\hline 22 & Glorioso Islands & $11.5468^{\circ} \mathrm{S}$ & $47.3258^{\circ} \mathrm{E}$ \\
\hline \multicolumn{4}{|c|}{ Chagos Archipelago } \\
\hline 23 & Blenheim Reef* & $5.2148^{\circ} \mathrm{S}$ & $72.4680^{\circ} \mathrm{E}$ \\
\hline 24 & Saloman & $5.3303^{\circ} \mathrm{S}$ & $72.2460^{\circ} \mathrm{E}$ \\
\hline 25 & Peros Banhos & $5.3542^{\circ} \mathrm{S}$ & $71.8489^{\circ} \mathrm{E}$ \\
\hline 26 & Egmont & $6.6586^{\circ} \mathrm{S}$ & $71.3523^{\circ} \mathrm{E}$ \\
\hline 27 & Diego Garcia & $7.3237^{\circ} \mathrm{S}$ & $72.4531^{\circ} \mathrm{E}$ \\
\hline
\end{tabular}

Table A.3. Atolls of the Eastern Indian Ocean. An asterisk $\left(^{*}\right)$ indicates an atoll reef. A dagger $(\dagger)$ indicates a closed lagoon.

\begin{tabular}{rlrrr} 
Atoll No. & Atoll Name & Alternative Name & Latitude & \multicolumn{1}{c}{ Longitude } \\
\hline 28 & North Keeling $^{\dagger}$ & Cocos & $11.8332^{\circ} \mathrm{S}$ & $96.8241^{\circ} \mathrm{E}$ \\
29 & South Keeling & Keeling & $12.1469^{\circ} \mathrm{S}$ & $96.8693^{\circ} \mathrm{E}$ \\
30 & Seringatapam Reef* & - & $13.6673^{\circ} \mathrm{S}$ & $122.0124^{\circ} \mathrm{E}$ \\
31 & Scott Reef* $^{*}$ & - & $14.0820^{\circ} \mathrm{S}$ & $121.8631^{\circ} \mathrm{E}$ \\
32 & Mermaid Reef*a $^{*}$ & - & $17.1247^{\circ} \mathrm{S}$ & $119.6288^{\circ} \mathrm{E}$ \\
33 & Clerke Reef* $^{\text {b }}$ & - & $17.3290^{\circ} \mathrm{S}$ & $119.3510^{\circ} \mathrm{E}$ \\
34 & Imperieuse Reef* $^{* \mathrm{C}}$ & - & $17.5871^{\circ} \mathrm{S}$ & $118.9318^{\circ} \mathrm{E}$ \\
\hline
\end{tabular}

${ }^{\mathrm{a}}$ Parts of rim dry at low water

${ }^{\mathrm{b}}$ Small sand cay at north

${ }^{\mathrm{c}}$ Two lagoons; large areas dry at low water

There are 37 islands, 12 atolls, 3 reefs and 5 submerged banks in the Lakshadweep group. Bryan (1953) lists 14 atolls although Ameni is a table reef island on an otherwise submerged platform; Androth has no lagoon (NASA photo ID: ISS002-E-7264). Neither is listed in Table A.4. Bangaram and Agatti (42) are two atolls on an unusual single platform joined by a flattened coralline shelf that joins their forereefs (Deshmukh et al., 2005). NGA Chart 63005 suggests that this shelf is at least $10 \mathrm{~m}$ deep and the coordinates listed in Table A.4 mark its center. Chetlat and Kiltan islands $(37,39)$ are growing and their 
lagoons are filling in (Wagle and Kunte, 1999). Other Lakshadweep descriptions are found in Sinha (1994) and Prakash (2015).

Table A.4. Atolls of Lakshadweep. An asterisk (*) indicates an atoll reef.

\begin{tabular}{rlccc} 
Atoll No. & Atoll Name & Alternative Name(s) & Latitude & Longitude \\
\hline 35 & Cherbaniani Reef* & Cheriapani & $12.3498^{\circ} \mathrm{N}$ & $71.9068^{\circ} \mathrm{E}$ \\
36 & Byramgore Reef* & - & $11.8942^{\circ} \mathrm{N}$ & $71.8011^{\circ} \mathrm{E}$ \\
37 & Chetlat & - & $11.6935^{\circ} \mathrm{N}$ & $72.7078^{\circ} \mathrm{E}$ \\
38 & Bitra Par Reef*a & - & $11.5482^{\circ} \mathrm{N}$ & $72.1636^{\circ} \mathrm{E}$ \\
39 & Kiltan & - & $11.4803^{\circ} \mathrm{N}$ & $73.0017^{\circ} \mathrm{E}$ \\
40 & Kademat & Kardamat, Kadmat & $11.2206^{\circ} \mathrm{N}$ & $72.7685^{\circ} \mathrm{E}$ \\
41 & Peremul Par* & Perumalpar & $11.1499^{\circ} \mathrm{N}$ & $72.0609^{\circ} \mathrm{E}$ \\
42 & Bangaram \& Agatti & - & $10.9128^{\circ} \mathrm{N}$ & $72.2279^{\circ} \mathrm{E}$ \\
43 & Ktolls & - & & \\
44 & Kavaratti & - & $10.5617^{\circ} \mathrm{N}$ & $72.6294^{\circ} \mathrm{E}$ \\
45 & Suheli Par & - & $10.1026^{\circ} \mathrm{N}$ & $73.6394^{\circ} \mathrm{E}$ \\
46 & Minicoy & - & $10.0774^{\circ} \mathrm{N}$ & $72.2915^{\circ} \mathrm{E}$ \\
& Minikoi & $8.2958^{\circ} \mathrm{N}$ & $73.0451^{\circ} \mathrm{E}$ \\
\hline
\end{tabular}

${ }^{\mathrm{a}}$ Island $\approx 3 \%$ of rim area

${ }^{\mathrm{b}}$ Island $\approx 6 \%$ of rim

There are 21 atolls in the Maldive group (Kench et al., 2009). Entries in Table A.5 are after Bryan (1953) with updated names. Tilladumatti/Miladhunmadulu (48a/b) is one atoll platform divided by a shelf break; separate names are given to the northern and southern sections. North Malosmadulu (50) and South Malosmadulu (51) are two atolls on the same platform. Toddu Island is part of a table reef and is not included in the table. Island areas of most large atolls with complex faro structure were not measured.

Table A.5. Atolls of the Maldives. An asterisk (*) indicates an atoll reef.

\begin{tabular}{rlccc} 
Atoll No. & Atoll Name & Alternative Name(s) & Latitude & Longitude \\
\hline 47 & Ihvandiffulu & Ihavandhippolu & $7.0279^{\circ} \mathrm{N}$ & $72.9124^{\circ} \mathrm{E}$ \\
$48 \mathrm{a}$ & Tilladumatti & Thiladhunmathi & $6.7164^{\circ} \mathrm{N}$ & $73.0161^{\circ} \mathrm{E}$ \\
$48 \mathrm{~b}$ & Miladhunmadulu & - & $5.9665^{\circ} \mathrm{N}$ & $73.2404^{\circ} \mathrm{E}$ \\
49 & Makaenudu $^{\mathrm{a}}$ & Maamakunudoo & $6.3094^{\circ} \mathrm{N}$ & $72.6161^{\circ} \mathrm{E}$ \\
50 & N. Malosmadulu & Maalhosmadulu & $5.5827^{\circ} \mathrm{N}$ & $72.9493^{\circ} \mathrm{E}$ \\
51 & S. Malosmadulu & - & $5.1798^{\circ} \mathrm{N}$ & $72.9937^{\circ} \mathrm{E}$ \\
52 & Fadiffolu & Faadhippolhu & $5.3905^{\circ} \mathrm{N}$ & $73.5200^{\circ} \mathrm{E}$ \\
53 & Goidhoo & Baa Atoll & $4.8529^{\circ} \mathrm{N}$ & $72.9244^{\circ} \mathrm{E}$ \\
54 & Gaha Faro*b & Gaa Faru & $4.7477^{\circ} \mathrm{N}$ & $73.4346^{\circ} \mathrm{E}$ \\
55 & Malé North & - & $4.4214^{\circ} \mathrm{N}$ & $73.5037^{\circ} \mathrm{E}$ \\
56 & Malé South & - & $3.9834^{\circ} \mathrm{N}$ & $73.4357^{\circ} \mathrm{E}$ \\
57 & Rasdhu & Rasdhoo & $4.2921^{\circ} \mathrm{N}$ & $72.9834^{\circ} \mathrm{E}$ \\
58 & Ari & - & $3.8300^{\circ} \mathrm{N}$ & $72.8500^{\circ} \mathrm{E}$ \\
59 & Fetadu & Feladu, Felidhe & $3.4608^{\circ} \mathrm{N}$ & $73.4660^{\circ} \mathrm{E}$ \\
60 & Vataru Reef* & - & $3.2479^{\circ} \mathrm{N}$ & $73.4331^{\circ} \mathrm{E}$ \\
& & - & $($ continued)
\end{tabular}


Table A.5. Atolls of the Maldives. (continued)

\begin{tabular}{rllll}
\hline Atoll No. & Atoll Name & Alternative Name(s) & Latitude & Longitude \\
\hline 61 & Faafu & North Nilandu Atoll & $3.1951^{\circ} \mathrm{N}$ & $72.9295^{\circ} \mathrm{E}$ \\
62 & Mulak & Mulaku & $2.9917^{\circ} \mathrm{N}$ & $73.5007^{\circ} \mathrm{E}$ \\
63 & Dhaalu & South Nilandu Atoll & $2.8372^{\circ} \mathrm{N}$ & $72.9340^{\circ} \mathrm{E}$ \\
64 & Kolomadulu $^{\mathrm{C}}$ & Kolhumadulu & $2.3764^{\circ} \mathrm{N}$ & $73.1045^{\circ} \mathrm{E}$ \\
65 & Haddummati & Hadhdhunmathi & $1.9212^{\circ} \mathrm{N}$ & $73.4046^{\circ} \mathrm{E}$ \\
66 & Suvadiva & Huvadhoo & $0.4824^{\circ} \mathrm{N}$ & $73.2750^{\circ} \mathrm{E}$ \\
67 & Addu & Seenu & $0.6490^{\circ} \mathrm{S}$ & $73.1674^{\circ} \mathrm{E}$ \\
\hline
\end{tabular}

${ }^{\mathrm{a}}$ Four small islands $\approx 6 \%$ of rim

${ }^{\mathrm{b}}$ Two islands $\approx 1.4 \%$ of rim

${ }^{\mathrm{c}}$ Islands $\approx 7.7 \%$ of rim

\section{WESTERN PACIFIC OCEAN 250 Atolls}

There are 250 atolls in the western Pacific Ocean, including the marginal seas of Indonesia, South China, and the Philippines. The South China Sea (Table A.6) exhibits three types of atolls, including those projecting from the deep ocean and those on the continental shelf and continental slope. Slope atolls are the most common; however, among the seventy that are listed by Guozhong (1998), several are not included here: Zhongsha (Macclesfield Bank, >19 m), Lilu (Reed bank, >16 m), Yongdeng and Lesi (Trident and Lys Shoals respectively, $>18 \mathrm{~m}$ ), Changtan (no English name-its position corresponds to the northern segment of Loaita Bank, >10 m), Nanwei (Rifleman Bank, several shallow areas at margins, but general depth > 20 m), Nanfangtan (Southern Bank, >13 m), and Mahuan (no English name, >45 m). These are large, mostly submerged, rimmed or partially rimmed banks. Banlu (Hardy Reef), $6 \mathrm{~km}$ diameter, also appears to be submerged. Andu (Ardasier Bank, >41 m) was eliminated for the same reason, but Ardasier Reef (116) is an atoll reef at the western end of Ardasier Bank and is retained here as listed by Guozhong (1998). Seahorse Shoal (82) is submerged but has a visible rim at 4-7 $\mathrm{m}$ and is tentatively included.

Dongdao (including Lincoln Island) was listed as an atoll, but it lacks a lagoon and is a table reef. Scarborough Shoal (76) is an oceanic atoll added to the list. Three atolls referred to (but not listed) by Guozhong on the continental shelf west of Sarawak (North and South Luconia Shoals) were not included due to poor satellite and chart description. Five atolls with significant natural islands are also noted: Xuande (70), Yongle (71), Zhongye (78), Daoming (83) and Zhenghe (85). Daoming (83) includes 25 ha Lankiam Cay and 6 ha Loaita Island but is a large, mostly subtidal atoll with several exposed reefs. Zhenghe (85) is also large and mostly subtidal, except for one 50 ha island; prominent reefs include Gaven, Petley and Eldad. Gaven Reef has been dredged and filled. Quyuantan (90) is a large atoll reef with numerous, mostly subtidal shoals, including V-shaped Whitsun, Johnson and Hughes reefs and one 8 ha island. Johnson and Hughes reefs have been dredged and filled. 
Table A.6. Atolls of the South China Sea. Almost all atolls of the South China Sea $(49 / 52=>94 \%)$ are natural atoll reefs (i.e., no islands or islands on $<5 \%$ of the rim); these are indicated by an asterisk (*). However, five have been dredged and filled; these are indicated by the Greek phi $(\Phi)$. Place names are from Gouzhong (1998), except as noted below. English names are from Hancox and Prescott (1995), Spalding et al., (2001), and NGA (2014a). Chart references: NGA 632, 93030, 93044, 93045, 93046, 93047, 93049; British Admiralty 94.

\begin{tabular}{|c|c|c|c|c|}
\hline Atoll No. & Atoll Name & Alternative Name(s) & Latitude & Longitude \\
\hline \multicolumn{5}{|c|}{ Isolated north } \\
\hline 68 & Dongsha*a $^{\mathrm{a}}$ & Pratas Reef & $20.6842^{\circ} \mathrm{N}$ & $116.8187^{\circ} \mathrm{E}$ \\
\hline & & Paracel Islands & & \\
\hline 69 & Beijiao* & North Reef & $17.0923^{\circ} \mathrm{N}$ & $111.5000^{\circ} \mathrm{E}$ \\
\hline 70 & Xuande $^{\mathrm{b}}$ & $\begin{array}{l}\text { Amphitrite group } \\
\text { including West Sand, } \\
\text { Tree Island }\end{array}$ & $16.9603^{\circ} \mathrm{N}$ & $112.2850^{\circ} \mathrm{E}$ \\
\hline 71 & Yongle & $\begin{array}{l}\text { Crescent group; } \\
\text { includes Yongxing } \\
\text { Island }\end{array}$ & $16.5000^{\circ} \mathrm{N}$ & $111.6799^{\circ} \mathrm{E}$ \\
\hline 72 & Yuzhuo* & Vuladdore & $16.3456^{\circ} \mathrm{N}$ & $112.0181^{\circ} \mathrm{E}$ \\
\hline 73 & Huaguang* & Discovery Reef & $16.2281^{\circ} \mathrm{N}$ & $111.6864^{\circ} \mathrm{E}$ \\
\hline 74 & Panshiyu* & Passau Keah & $16.0519^{\circ} \mathrm{N}$ & $111.7866^{\circ} \mathrm{E}$ \\
\hline 75 & Langhua* & $\begin{array}{l}\text { Bombay Reef } \\
\text { Isolated east }\end{array}$ & $16.0433^{\circ} \mathrm{N}$ & $112.5246^{\circ} \mathrm{E}$ \\
\hline 76 & Huangyan Dao* & $\begin{array}{l}\text { Scarborough Shoal } \\
\text { Spratly Group }\end{array}$ & $15.1462^{\circ} \mathrm{N}$ & $117.7701^{\circ} \mathrm{E}$ \\
\hline 77 & Shuangzi*c & North Danger Reef & $11.4107^{\circ} \mathrm{N}$ & $114.3549^{\circ} \mathrm{E}$ \\
\hline 78 & Zhongye*d & Thitu Reef West & $11.0505^{\circ} \mathrm{N}$ & $114.2445^{\circ} \mathrm{E}$ \\
\hline 79 & Zhongya* & Thitu Reef East & $11.0700^{\circ} \mathrm{N}$ & $114.3500^{\circ} \mathrm{E}$ \\
\hline 80 & Zhubi $^{\Phi}$ & Subi & $10.9238^{\circ} \mathrm{N}$ & $114.0863^{\circ} \mathrm{E}$ \\
\hline 81 & Cailun* & Irving Reef & $10.8718^{\circ} \mathrm{N}$ & $114.9198^{\circ} \mathrm{E}$ \\
\hline 82 & Haima* & Seahorse Shoal & $10.7931^{\circ} \mathrm{N}$ & $117.7809^{\circ} \mathrm{E}$ \\
\hline 83 & Daoming* & Loaita Bank & $10.7399^{\circ} \mathrm{N}$ & $114.4892^{\circ} \mathrm{E}$ \\
\hline 84 & Jiesheng* & Jackson & $10.4975^{\circ} \mathrm{N}$ & $115.7546^{\circ} \mathrm{E}$ \\
\hline 85 & Zhenghe* & Tizard Bank & $10.2637^{\circ} \mathrm{N}$ & $114.3804^{\circ} \mathrm{E}$ \\
\hline 86 & Hejiao* & Hopps Reef & $10.2507^{\circ} \mathrm{N}$ & $115.3665^{\circ} \mathrm{E}$ \\
\hline 87 & Sanjiao*e & $\begin{array}{l}\text { Livock Reef, } \\
\text { Southampton Reefs }\end{array}$ & $10.1892^{\circ} \mathrm{N}$ & $115.2967^{\circ} \mathrm{E}$ \\
\hline 88 & Daxian* & Great Discovery Reef & $10.0565^{\circ} \mathrm{N}$ & $113.8530^{\circ} \mathrm{E}$ \\
\hline 89 & Meiji $^{\Phi}$ & Mischief Reef & $9.9017^{\circ} \mathrm{N}$ & $115.5362^{\circ} \mathrm{E}$ \\
\hline 90 & Quyuantan* & Union Bank & $9.8673^{\circ} \mathrm{N}$ & $114.4714^{\circ} \mathrm{E}$ \\
\hline 91 & Renai* & $2^{\text {nd }}$ Thomas Shoal & $9.7504^{\circ} \mathrm{N}$ & $115.8649^{\circ} \mathrm{E}$ \\
\hline 92 & Xianbin* & Sabina Shoals & $9.7475^{\circ} \mathrm{N}$ & $116.4905^{\circ} \mathrm{E}$ \\
\hline 93 & Yongshu $^{\Phi}$ & Fiery Cross Reef & $9.6118^{\circ} \mathrm{N}$ & $112.9710^{\circ} \mathrm{E}$ \\
\hline 94 & Niuchelun* & Boxall Reef & $9.6001^{\circ} \mathrm{N}$ & $116.1664^{\circ} \mathrm{E}$ \\
\hline 95 & Pengbuo* & Bombay Shoal & $9.4572^{\circ} \mathrm{N}$ & $116.9274^{\circ} \mathrm{E}$ \\
\hline 96 & Xiane* & Alicia Annie Reef & $9.3757^{\circ} \mathrm{N}$ & $115.4444^{\circ} \mathrm{E}$ \\
\hline 97 & Xinyi* & $1^{\text {st }}$ Thomas Shoal & $9.3281^{\circ} \mathrm{N}$ & $115.9326^{\circ} \mathrm{E}$ \\
\hline 98 & Haikou* & NE Investigator Shoal & $9.1762^{\circ} \mathrm{N}$ & $116.4609^{\circ} \mathrm{E}$ \\
\hline 99 & Jianzhang* & Royal Captain Shoal & $9.0448^{\circ} \mathrm{N}$ & $\begin{array}{l}116.6648^{\circ} \mathrm{E} \\
\text { (continued) }\end{array}$ \\
\hline
\end{tabular}


Table A.6. Atolls of the South China Sea. (continued)

\begin{tabular}{|c|c|c|c|c|}
\hline Atoll No. & Atoll Name & Alternative Name(s) & Latitude & Longitude \\
\hline 100 & Bisheng*f & Pearson Reef & $8.9538^{\circ} \mathrm{N}$ & $113.6741^{\circ} \mathrm{E}$ \\
\hline 101 & Yinqing ${ }^{g}$ & Central London Reefs & $8.9301^{\circ} \mathrm{N}$ & $112.3497^{\circ} \mathrm{E}$ \\
\hline 102 & Banyue* & Half Moon Shoal & $8.9018^{\circ} \mathrm{N}$ & $116.2738^{\circ} \mathrm{E}$ \\
\hline 103 & Yinqing West* & West London Reef & $8.8581^{\circ} \mathrm{N}$ & $112.2239^{\circ} \mathrm{E}$ \\
\hline 104 & Yinging East* & East London Reef & $8.8222^{\circ} \mathrm{N}$ & $112.5966^{\circ} \mathrm{E}$ \\
\hline 105 & Tianlan* & Pigeon Reef & $8.8569^{\circ} \mathrm{N}$ & $114.6560^{\circ} \mathrm{E}$ \\
\hline 106 & Huayang $^{\Phi}$ & Cuarteron Reef & $8.8603^{\circ} \mathrm{N}$ & $112.8400^{\circ} \mathrm{E}$ \\
\hline 107 & Lisheng* & Alison Reef & $8.8042^{\circ} \mathrm{N}$ & $113.9894^{\circ} \mathrm{E}$ \\
\hline 108 & Nanhua* & $\begin{array}{l}\text { Cornwallis South } \\
\text { Reef }\end{array}$ & $8.7121^{\circ} \mathrm{N}$ & $114.1854^{\circ} \mathrm{E}$ \\
\hline 109 & Riji* & Ladd Reef & $8.6663^{\circ} \mathrm{N}$ & $111.6755^{\circ} \mathrm{E}$ \\
\hline 110 & Siling*h & Commodore Reef & $8.3590^{\circ} \mathrm{N}$ & $115.2260^{\circ} \mathrm{E}$ \\
\hline 111 & Baijiao* & Barque-Canada Reef & $8.1740^{\circ} \mathrm{N}$ & $113.3121^{\circ} \mathrm{E}$ \\
\hline 112 & Yuya* & Investigator Shoal & $8.1171^{\circ} \mathrm{N}$ & $114.6890^{\circ} \mathrm{E}$ \\
\hline 113 & Boji* & $\begin{array}{l}\text { Enloa Reef or Erica } \\
\text { Reef }\end{array}$ & $8.1065^{\circ} \mathrm{N}$ & $114.1319^{\circ} \mathrm{E}$ \\
\hline 114 & Nanhai* & Mariveles Reef & $7.9736^{\circ} \mathrm{N}$ & $113.9148^{\circ} \mathrm{E}$ \\
\hline 115 & Guangzing* & Dallas Reef & $7.6199^{\circ} \mathrm{N}$ & $113.7970^{\circ} \mathrm{E}$ \\
\hline 116 & Guangzingzi* & Ardasier Reef & $7.6185^{\circ} \mathrm{N}$ & $113.9371^{\circ} \mathrm{E}$ \\
\hline 117 & $\operatorname{Danwan}^{\Phi}$ & $\begin{array}{l}\text { Swallow or Layang } \\
\text { Layang }\end{array}$ & $7.3737^{\circ} \mathrm{N}$ & $113.8282^{\circ} \mathrm{E}$ \\
\hline 118 & Huanglu* & Royal Charlotte Reef & $6.9421^{\circ} \mathrm{N}$ & $113.5799^{\circ} \mathrm{E}$ \\
\hline 119 & Nantong*i & Louisa Reef & $6.3333^{\circ} \mathrm{N}$ & $113.2666^{\circ} \mathrm{E}$ \\
\hline \multicolumn{5}{|c|}{${ }^{\mathrm{a}}$ Island $\approx 2 \%$ of rim } \\
\hline \multicolumn{5}{|c|}{${ }^{\mathrm{b}}$ Lagoon within a comma-like atoll } \\
\hline \multicolumn{5}{|c|}{${ }^{\mathrm{c}}$ Two small cays $\approx 2 \%$ of rim } \\
\hline \multicolumn{5}{|c|}{ d 32 ha cay with airstrip, $<1 \%$ of rim } \\
\hline \multirow{2}{*}{\multicolumn{5}{|c|}{$\begin{array}{l}\text { e Guozhong (1998) lists this as Libai; however, that name could not be resolved with } \\
\text { available databases so the name Sanjiao, used by Wang and Li (2009), was substituted } \\
\text { f Small cay at northeast }\end{array}$}} \\
\hline & & & & \\
\hline \multicolumn{5}{|c|}{${ }^{\mathrm{g}} 1.8 \mathrm{~km}$ atoll, two small cays, $\approx 24 \%$ of rim } \\
\hline \multicolumn{5}{|c|}{ h Two lagoons } \\
\hline No satellite & . & & & \\
\hline
\end{tabular}

The Philippines includes just two atolls (Table A.7). Bryan (1953) noted Sibutu atoll (121), which at the time was placed in Indonesia, but he did not include it in his checklist due to its tilted condition. Reflecting this, the atoll island east of the lagoon is more than $10 \mathrm{~m}$ elevation. Farther east, boomerangshaped Sibutu Island is elevated more than $20 \mathrm{~m}$ (see supplemental material).

In Indonesia, 55 atolls are listed by Tomascik et al. (1997), including one that is raised and has no lagoon, three that are submerged, and six almost-atolls. In addition to these ten, Gosong Aurora is submerged (-7 m; Bryan, 1953; no imagery), Pulau Bepondi is a table reef, and one of five unnamed atolls $\left(1^{\circ} 25^{\prime} \mathrm{S}, 127^{\circ} 25^{\prime} \mathrm{E}\right)$ could not be located. None of these (a total of 13) are included here. The total of 42 atolls listed in Table A.8 include 14 of 15 entries by Bryan (1953) and two-Taka Rewataya (127) and Rani (165)—not in Tomascik et al.'s (1997) list.

Maratua (122) is elevated to $90 \mathrm{~m}$ on its northwest side only; the lagoon is otherwise open. Kakaban (123) is an uplifted atoll with a closed marine lagoon. Paternoster and Sadapur atolls (130 and 131, 
respectively) are composed of a series of low islands on largely submerged rims; Sadapur is a large, sinusoidally arranged E-W atoll island complex. Tomascik et al. (1997) included Pasir Tengah and East Atoll (139 and 140 in the present list), but Bryan (1953) did not include them due to their proximity to the high Togian Islands. There are numerous atoll reefs that have not been described in this region, e.g. unnamed twin atolls (147) in the Banda Sea, added by author.

Table A.7. Atolls of the Philippines. A dagger $(\dagger)$ indicates a closed lagoon.

\begin{tabular}{rlll} 
Atoll No. & Atoll Name & Latitude & Longitude \\
\hline 120 & $\begin{array}{l}\text { Tubbataha (North } \\
\text { and South) }\end{array}$ & $8.8500^{\circ} \mathrm{N}$ & $119.9333^{\circ} \mathrm{E}$ \\
121 & Sibutu & $4.7066^{\circ} \mathrm{N}$ & $119.3668^{\circ} \mathrm{E}$ \\
\hline
\end{tabular}

Table A.8. Atolls of Indonesia. An asterisk (*) indicates an atoll reef. A dagger ( $\dagger$ ) indicates a closed lagoon. NGA charts consulted: 632, 72021, 73000.

\begin{tabular}{|c|c|c|c|c|}
\hline Atoll No. & Atoll Name & Alternative Name & Latitude & Longitude \\
\hline \multicolumn{5}{|c|}{ Sulawesi Sea } \\
\hline 122 & Maratua & - & $2.2060^{\circ} \mathrm{N}$ & $118.6347^{\circ} \mathrm{E}$ \\
\hline 123 & $\operatorname{Kakaban}^{\dagger}$ & - & $2.1452^{\circ} \mathrm{N}$ & $118.5345^{\circ} \mathrm{E}$ \\
\hline 124 & Muaras* & - & $1.9009^{\circ} \mathrm{N}$ & $118.8740^{\circ} \mathrm{E}$ \\
\hline \multicolumn{5}{|c|}{ Java Sea } \\
\hline 125 & Kulukalukuang & - & $5.2034^{\circ} \mathrm{S}$ & $117.6541^{\circ} \mathrm{E}$ \\
\hline 126 & Dewakang Besar & Laars & $5.4766^{\circ} \mathrm{S}$ & $118.4461^{\circ} \mathrm{E}$ \\
\hline 127 & Taka Rewataya $^{\dagger}$ & - & $6.0676^{\circ} \mathrm{S}$ & $118.9207^{\circ} \mathrm{E}$ \\
\hline 128 & Sabalana & - & $6.8664^{0} \mathrm{~S}$ & $119.0737^{\circ} \mathrm{E}$ \\
\hline 129 & Sapoeka & - & $7.0971^{\circ} \mathrm{S}$ & $118.1448^{\circ} \mathrm{E}$ \\
\hline 130 & Paternoster & - & $7.4012^{\circ} \mathrm{S}$ & $117.6968^{\circ} \mathrm{E}$ \\
\hline 131 & Sadapur & Zandbuis & $7.4753^{\circ} \mathrm{S}$ & $117.5924^{\circ} \mathrm{E}$ \\
\hline \multicolumn{5}{|c|}{ Flores Sea/Makassar Strait } \\
\hline 132 & Sogori* & - & $5.3622^{\circ} \mathrm{S}$ & $121.7567^{\circ} \mathrm{E}$ \\
\hline 133 & Taka Garlarang* & - & $6.4903^{\circ} \mathrm{S}$ & $121.2501^{\circ} \mathrm{E}$ \\
\hline 134 & Taka Bone Rate* & Tijger & $6.6520^{\circ} \mathrm{S}$ & $121.1363^{0} \mathrm{E}$ \\
\hline 135 & Kakabia $^{\dagger}$ & - & $6.9078^{\circ} \mathrm{S}$ & $122.2279^{\circ} \mathrm{E}$ \\
\hline 136 & Taka Bassi* & Karang Marianne & $7.5157^{\circ} \mathrm{S}$ & $121.1952^{\circ} \mathrm{E}$ \\
\hline 137 & Pasir Layaran*a & Pasir Lajaran & $7.6667^{\circ} \mathrm{S}$ & $122.3000^{\circ} \mathrm{E}$ \\
\hline 138 & Gosong Boni* & - & $8.3837^{\circ} \mathrm{S}$ & $122.2319^{\circ} \mathrm{E}$ \\
\hline \multicolumn{5}{|c|}{ Tomini Gulf/Molucca Sea } \\
\hline 139 & Pasir Tengah* & & $0.4350^{\circ} \mathrm{S}$ & $121.6453^{\circ} \mathrm{E}$ \\
\hline 140 & East Atoll* & No Indonesian name & $0.4178^{\circ} \mathrm{S}$ & $121.6841^{\circ} \mathrm{E}$ \\
\hline 141 & Karang Lalanga* & - & $1.0589^{\circ} \mathrm{S}$ & $120.6695^{\circ} \mathrm{E}$ \\
\hline \multicolumn{5}{|c|}{ Banda Sea } \\
\hline 142 & no name $1^{*}$ & - & $1.9860^{\circ} \mathrm{S}$ & $123.2011^{\circ} \mathrm{E}$ \\
\hline 143 & Pulau Panteh* & - & $2.0058^{\circ} \mathrm{S}$ & $123.4180^{\circ} \mathrm{E}$ \\
\hline 144 & Pulau Maringki* & Pulau Sitjeh & $2.1081^{\circ} \mathrm{S}$ & $123.2538^{\circ} \mathrm{E}$ \\
\hline 145 & no name $2 * b$ & - & $2.1900^{\circ} \mathrm{S}$ & $123.4401^{\circ} \mathrm{E}$ \\
\hline 146 & Pangajarang* & - & $3.3696^{\circ} \mathrm{S}$ & $122.8543^{\circ} \mathrm{E}$ \\
\hline 147 & no name $3 * \mathrm{C}$ & - & $3.3705^{\circ} \mathrm{S}$ & $\begin{array}{l}122.8126^{\circ} \mathrm{E} \\
\text { (continued) }\end{array}$ \\
\hline
\end{tabular}


Table A.8. Atolls of Indonesia. (continued)

\begin{tabular}{|c|c|c|c|c|}
\hline Atoll No. & Atoll Name & Alternative Name & Latitude & Longitude \\
\hline 148 & Bobubu* & Bolewang & $3.4775^{\circ} \mathrm{S}$ & $122.9572^{\circ} \mathrm{E}$ \\
\hline 149 & Saponda Utara ${ }^{\mathrm{d}}$ & - & $3.8836^{\circ} \mathrm{S}$ & $122.8128^{\circ} \mathrm{E}$ \\
\hline 150 & Kepulauan Lucipara*e & - & $5.4941^{\circ} \mathrm{S}$ & $127.5412^{\circ} \mathrm{E}$ \\
\hline 151 & Karang Kapotta* & Karang Kapota & $5.5216^{\circ} \mathrm{S}$ & $123.4383^{\circ} \mathrm{E}$ \\
\hline 152 & Karang Skaro* & Skaro Reef & $5.5800^{\circ} \mathrm{S}$ & $127.4700^{\circ} \mathrm{E}$ \\
\hline 153 & Pasir Ndaa*f & - & $5.6538^{\circ} \mathrm{S}$ & $124.0473^{\circ} \mathrm{E}$ \\
\hline 154 & Karang Koro Maha* & - & $5.7427^{\circ} \mathrm{S}$ & $124.1848^{\circ} \mathrm{E}$ \\
\hline 155 & Lintea & Pulau So. Lentea & $5.8310^{\circ} \mathrm{S}$ & $123.8638^{\circ} \mathrm{E}$ \\
\hline 156 & no name $4^{*}$ & - & $5.8200^{\circ} \mathrm{S}$ & $123.6390^{\circ} \mathrm{E}$ \\
\hline 157 & Karang Kaledupa* & Karang Kaledoepa & $5.7481^{\circ} \mathrm{S}$ & $123.6959^{\circ} \mathrm{E}$ \\
\hline 158 & Karang Koka* & - & $6.0722^{\circ} \mathrm{S}$ & $124.3558^{\circ} \mathrm{E}$ \\
\hline 159 & Meatimiarang & $\begin{array}{l}\text { Meatij Miarang } \\
\text { Halmahera Sea }\end{array}$ & $8.2708^{\circ} \mathrm{S}$ & $128.4589^{\circ} \mathrm{E}$ \\
\hline 160 & Pulau Ju & & $0.0400^{\circ} \mathrm{S}$ & $129.6203^{\circ} \mathrm{E}$ \\
\hline 161 & Kepuluan Widi West & Pulau Kokota & $0.6389^{\circ} \mathrm{S}$ & $128.5571^{\circ} \mathrm{E}$ \\
\hline 162 & Kepuluan Widi East ${ }^{g}$ & Pulau Sukar & $0.5665^{\circ} \mathrm{S}$ & $128.3667^{\circ} \mathrm{E}$ \\
\hline 163 & Pasir Raja ${ }^{\mathrm{h}}$ & - & $0.5907^{\circ} \mathrm{N}$ & $127.4723^{\circ} \mathrm{E}$ \\
\hline \multicolumn{5}{|c|}{ West Papua } \\
\hline 164 & Mapia $^{\dagger i}$ & - & $0.8741^{\circ} \mathrm{N}$ & $134.3061^{\circ} \mathrm{E}$ \\
\hline 165 & Rani & Roeni & $0.8786^{\circ} \mathrm{S}$ & $135.4355^{\circ} \mathrm{E}$ \\
\hline 166 & Mioswundi & Pulau Pai & $1.2700^{\circ} \mathrm{S}$ & $136.4000^{\circ} \mathrm{E}$ \\
\hline
\end{tabular}

\footnotetext{
position shown in supplementary material online

${ }^{\mathrm{b}}$ Island area $=<1 \%$ of rim

${ }^{\mathrm{C}}$ Twin atolls not previously reported

${ }^{\mathrm{d}}$ Island $\approx 5.0 \%$ of rim area

e Three small islands $\approx 4.6 \%$ of rim (by ImageJ—see "Methods")

${ }^{\mathrm{f}}$ Island is $\approx 3 \%$ of rim

g Two atolls, one platform

${ }^{\mathrm{h}}$ Two atolls, one platform?

${ }^{\mathrm{i}}$ Islands $\approx 6.9 \%$ of rim
}

${ }^{a}$ No satellite imagery available; coordinates from relief on Google Earth and charted

Twenty-nine atolls are present in the area from Papua New Guinea to Vanuatu (Table A.9). Malum and Nuguria $(181,182)$ are paired but are listed as separate atolls. Nissan Island $\left(4.54^{\circ} \mathrm{S}, 154.20^{\circ} \mathrm{E}\right)$, which is elevated with a small island in the lagoon center (a possible almost-atoll), is paired with Pinipir Atoll (183), $2 \mathrm{~km}$ to the north (Spriggs, 1991). Nissan and Pinipir together are referred to as the Green Islands. Redlick (178) is adjacent to a possible almost atoll; satellite imagery of both Redlick and the nearby (possible) almost atoll is available in the supplementary material online. Three poorly known Santa Cruz atolls (192-194) added by the author are additions to Bryan's (1953) list.

A number of islands in the same area are not considered atolls or included in this list: Manu, Aua, Wuwulu, and Asia (West Papua) are island platforms with no lagoon (table reefs); Hermit Island $\left(1.54^{\circ} \mathrm{N}\right.$, $148.08^{\circ} \mathrm{E}$ ) and Sikaiana (Stewart Islands, $8.41^{\circ} \mathrm{S}, 162.89^{\circ} \mathrm{E}$ ) are almost-atolls (Spalding et al., 2001); Bellona and Rennell are uplifted atolls. Other islands not listed include: three of the Admiralty Islands (Johnston, Purdy and Western), which are too small or otherwise lack sufficient detail (Landsat; Google Earth; eol.jsc.nasa; and NGA, 2005) to distinguish their structure; Papialou, Sae, Palawat and Tong, 
which appear to be table islands and lack lagoons; and Sabben Reef, which could not be adequately distinguished from other types of reefs around the high island of Manus.

Table A.9. Atolls from Papua New Guinea to Vanuatu. An asterisk (*) indicates an atoll reef. A dagger ( $\dagger$ ) indicates a closed lagoon.

\begin{tabular}{|c|c|c|c|c|}
\hline Atoll No. & Atoll Name & Alternative Name(s) & Latitude & Longitude \\
\hline \multicolumn{5}{|c|}{ North of Papua New Guinea $^{\text {a }}$} \\
\hline 167 & Laualau & $\begin{array}{l}\text { Kat Island, } \\
\text { Heina Islands }\end{array}$ & $1.1257^{\circ} \mathrm{S}$ & $144.3870^{\circ} \mathrm{E}$ \\
\hline 168 & Analtin $^{\dagger}$ & - & $1.1263^{\circ} \mathrm{S}$ & $144.3952^{\circ} \mathrm{E}$ \\
\hline 169 & Ninigo & Pelleluhu Islands & $1.3121^{\circ} \mathrm{S}$ & $144.2766^{\circ} \mathrm{E}$ \\
\hline 170 & $\operatorname{Liot}^{\dagger}$ & - & $1.4103^{\circ} \mathrm{S}$ & $144.5115^{\circ} \mathrm{E}$ \\
\hline 171 & $\mathrm{Sama}^{\dagger}$ & - & $1.4032^{\circ} \mathrm{S}$ & $144.0808^{\circ} \mathrm{E}$ \\
\hline 172 & Sumasama $^{\dagger}$ & - & $1.4810^{\circ} \mathrm{S}$ & $144.0458^{\circ} \mathrm{E}$ \\
\hline 173 & Awin $^{\dagger}$ & - & $1.6490^{\circ} \mathrm{S}$ & $144.0179^{\circ} \mathrm{E}$ \\
\hline \multicolumn{5}{|c|}{ Papua New Guinea East Islands } \\
\hline 174 & Budibudi & - & $9.2862^{\circ} \mathrm{S}$ & $153.6736^{\circ} \mathrm{E}$ \\
\hline 175 & Egum & - & $9.4100^{\circ} \mathrm{S}$ & $151.9400^{\circ} \mathrm{E}$ \\
\hline 176 & Gallows Reef* & - & $10.2843^{\circ} \mathrm{S}$ & $151.1575^{\circ} \mathrm{E}$ \\
\hline 177 & Conflict & $\begin{array}{l}\text { Irai Island, and } 10 \text { other } \\
\text { islands }\end{array}$ & $10.7804^{\circ} \mathrm{S}$ & $151.7980^{\circ} \mathrm{E}$ \\
\hline 178 & Redlick* & $\begin{array}{l}\text { Part of the Deboyne } \\
\text { Islands, northern } \\
\text { Louisiade Archipelago }\end{array}$ & $10.8735^{\circ} \mathrm{S}$ & $152.5466^{\circ} \mathrm{E}$ \\
\hline 179 & Long Reef* & - & $11.1741^{\circ} \mathrm{S}$ & $151.5782^{\circ} \mathrm{E}$ \\
\hline 180 & Bramble Haven*b & - & $11.2299^{\circ} \mathrm{S}$ & $152.0092^{\circ} \mathrm{E}$ \\
\hline \multicolumn{5}{|c|}{ Bismarck Archipelago } \\
\hline 181 & Malum $^{\mathrm{c}}$ & - & $3.1461^{\circ} \mathrm{S}$ & $154.4937^{\circ} \mathrm{E}$ \\
\hline 182 & Nuguria & Abgarris & $3.3195^{\circ} \mathrm{S}$ & $154.6854^{\circ} \mathrm{E}$ \\
\hline 183 & Pinipir & Pinipel & $4.4000^{\circ} \mathrm{S}$ & $154.1201^{\circ} \mathrm{E}$ \\
\hline 184 & Takuu*d & $\begin{array}{l}\text { Mortlock Atoll, } \\
\text { Nuugurigia }\end{array}$ & $4.7537^{\circ} \mathrm{S}$ & $156.9735^{\circ} \mathrm{E}$ \\
\hline 185 & Kilinailau*e & $\begin{array}{l}\text { Carteret Atoll, Tulun } \\
\text { Solomon Islands }\end{array}$ & $4.7600^{\circ} \mathrm{S}$ & $155.3899^{\circ} \mathrm{E}$ \\
\hline 186 & Nukumanu & - & $4.5429^{\circ} \mathrm{S}$ & $159.3974^{\circ} \mathrm{E}$ \\
\hline 187 & Ontong Java*f & - & $5.3490^{\circ} \mathrm{S}$ & $159.3282^{\circ} \mathrm{E}$ \\
\hline 188 & Candelaria Reef* & Roncador & $6.1985^{\circ} \mathrm{S}$ & $159.3805^{\circ} \mathrm{E}$ \\
\hline 189 & $\begin{array}{l}\text { Indispensable Reef } \\
\text { North* }\end{array}$ & 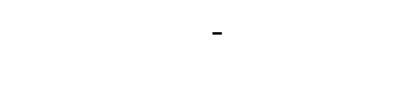 & $12.3148^{\circ} \mathrm{S}$ & $160.0813^{\circ} \mathrm{E}$ \\
\hline 190 & $\begin{array}{l}\text { Indispensable Reef } \\
\text { Middle* }\end{array}$ & - & $12.6527^{\circ} \mathrm{S}$ & $160.3827^{\circ} \mathrm{E}$ \\
\hline 191 & $\begin{array}{l}\text { Indispensable Reef } \\
\text { South* }\end{array}$ & - & $12.9444^{\circ} \mathrm{S}$ & $160.5866^{\circ} \mathrm{E}$ \\
\hline \multicolumn{5}{|c|}{ Santa Cruz } \\
\hline 192 & Nupani*g & - & $10.0834^{\circ} \mathrm{S}$ & $165.7290^{\circ} \mathrm{E}$ \\
\hline 193 & Nukapu ${ }^{\mathrm{h}}$ & - & $10.0906^{\circ} \mathrm{S}$ & $166.0389^{\circ} \mathrm{E}$ \\
\hline 194 & Numa Miombilou ${ }^{\mathrm{i}}$ & The Great Reef & $10.2280^{\circ} \mathrm{S}$ & $\begin{array}{r}166.2353^{\circ} \mathrm{E} \\
\text { (continued) }\end{array}$ \\
\hline
\end{tabular}


Table A.9. Atolls from Papua New Guinea to Vanuatu. (continued)

\begin{tabular}{|c|c|c|c|}
\hline Atoll No. Atoll Name & Alternative Name(s) & Latitude & Longitude \\
\hline \multicolumn{4}{|c|}{ Vanuatu } \\
\hline Rowa & - & $13.6239^{\circ} \mathrm{S}$ & $167.5185^{\circ} \mathrm{E}$ \\
\hline \multicolumn{4}{|c|}{ a Northern-most of the Ninigo group, a cluster of seven atolls (167-173) } \\
\hline \multicolumn{4}{|c|}{${ }^{\mathrm{b}}$ Tomard Islands $\approx 1.4 \%$ of rim } \\
\hline \multicolumn{4}{|c|}{${ }^{\mathrm{C}}$ Islands $>10 \%$ of rim } \\
\hline \multicolumn{4}{|l|}{${ }^{\mathrm{d}}$ Islands $\approx 3.2 \%$ of rim area } \\
\hline \multicolumn{4}{|l|}{${ }^{\mathrm{e}}$ Islands $\approx 1.6 \%$ of rim area } \\
\hline \multicolumn{4}{|l|}{$\mathrm{f}>30$ islands $\approx 2.2 \%$ of rim } \\
\hline \multicolumn{4}{|l|}{${ }^{\mathrm{g}}$ Islands $\approx 1.9 \%$ of rim } \\
\hline \multicolumn{4}{|l|}{${ }^{\mathrm{h}}$ Islands $\approx 6.5 \%$ of rim } \\
\hline i Includes Fenualoa Island & 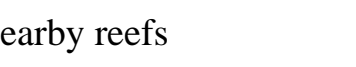 & & \\
\hline
\end{tabular}

In Fiji, Bryan's (1953) eight entries are conservatively increased to 25 (Table A.10). Of the entries by Bryan (1953), Tuvana-i-tholo, Tuvaba-i-Ra, Vatauuna and Niambo are table reefs and are thus not included here; Nggelelevu (Qelelevu; 197), Wailangilala (204), Nukumbasanga (199), and NukusemanuNanuka (200) are partly elevated limestone structures (Aggasiz, 1899). Several atolls listed here are small (e.g., Lailai [203] and Momo [212] are 2-3 km across by Landsat); Pitman (201) is $<2 \mathrm{~km}$. NukusemanuNanuku Reefs (200) was formerly Ringgold Atoll (Davis, 1928); its rim is continuous and elongated, but largely submerged in the center, except for patches along the eastern portion referred to as Heemskereq Reefs (see NGA map 83500).

In addition to several small atolls that are undescribed, there are many almost-atolls, such as North Astrolabe Reef to the south of Suva; Budd Reef (Vuana Levu) in the Ringgold group; and Exploring Isles, Reid, Argo reefs (Bukatatanoa), Aiwa and Oneata in the Lau group (Davis, 1928; Ladd, 1977; Spalding et al., 2001). Ceva-i-Ra, listed by Bryan, is a tiny remote atoll with an island in the lagoon, and for that reason it is not included, nor are Thakau Vau, Vuata Ono and Oni-i-Lau, atoll-like structures in the Lau Islands that display very shallow lagoons and are poorly described. Ringgold and Lau Islands atolls rise from a $1000 \mathrm{~m}$ deep plateau.

Table A.10. Atolls of Fiji. An asterisk (*) indicates an atoll reef. Thakau is the term for “reef” in Fijian. NGA map reference 83500.

\begin{tabular}{|c|c|c|c|c|}
\hline Atoll No. & Atoll Name & Alternative Name & Latitude & Longitude \\
\hline \multicolumn{5}{|c|}{ Ringgold Islands } \\
\hline 196 & Thakau Vuvovuvo*a & Thakau Vuthovutho & $16.0956^{\circ} \mathrm{S}$ & $179.5606^{\circ} \mathrm{W}$ \\
\hline 197 & Qelelevu*a,b & Nggelelevu & $16.1070^{\circ} \mathrm{S}$ & $179.2810^{\circ} \mathrm{W}$ \\
\hline 198 & Thakau Matacucu*a & Thakau Matathuthu & $16.1478^{\circ} \mathrm{S}$ & $179.6630^{\circ} \mathrm{W}$ \\
\hline 199 & Nukumbasanga Reef ${ }^{\text {c,d,e }}$ & Nuku Mbasanga & $16.3101^{\circ} \mathrm{S}$ & $179.2631^{\circ} \mathrm{W}$ \\
\hline 200 & $\begin{array}{l}\text { Nukusemanu-Nanuku } \\
\text { Reefs* }\end{array}$ & Ringgold Atoll & $\begin{array}{l}16.2770^{\circ} \mathrm{S} \\
\text { to }\end{array}$ & $\begin{array}{l}179.4602^{\circ} \mathrm{W} \\
\text { to }\end{array}$ \\
\hline & & & $16.7177^{\circ} \mathrm{S}$ & $179.4503^{\circ} \mathrm{W}$ \\
\hline 201 & Pitman Reef*a & - & $16.4253^{\circ} \mathrm{S}$ & $179.5395^{\circ} \mathrm{W}$ \\
\hline 202 & Motua Levu* & - & $16.6983^{\circ} \mathrm{S}$ & $179.6273^{\circ} \mathrm{W}$ \\
\hline 203 & Motua Lailai* & - & $16.7166^{\circ} \mathrm{S}$ & $\begin{array}{r}179.5566^{\circ} \mathrm{W} \\
\text { (continued) }\end{array}$ \\
\hline
\end{tabular}


Table A.10. Atolls of Fiji. (continued)

\begin{tabular}{llccc}
\hline Atoll No. Atoll Name & Alternative Name & Latitude & Longitude \\
\hline & & Lau Islands & & \\
204 & Wailangilala*c,d,f & - & $16.7732^{\circ} \mathrm{S}$ & $179.1073^{\circ} \mathrm{W}$ \\
205 & Duff Reef*c & - & $16.7995^{\circ} \mathrm{S}$ & $178.9453^{\circ} \mathrm{W}$ \\
206 & Dibbles Reef*a & - & $16.9764^{\circ} \mathrm{S}$ & $178.9790^{\circ} \mathrm{W}$ \\
207 & Williamson Reef*a & - & $17.0632^{\circ} \mathrm{S}$ & $179.0047^{\circ} \mathrm{W}$ \\
208 & Bell Reef*a & - & $17.0481^{\circ} \mathrm{S}$ & $178.9489^{\circ} \mathrm{W}$ \\
209 & Malevuvu Reef*a & - & $17.4130^{\circ} \mathrm{S}$ & $178.6779^{\circ} \mathrm{W}$ \\
210 & Vekai*a & - & $17.5599^{\circ} \mathrm{S}$ & $179.8241^{\circ} \mathrm{W}$ \\
211 & Thakau Tambu*a & - & $17.6635^{\circ} \mathrm{S}$ & $178.5430^{\circ} \mathrm{W}$ \\
212 & Thakau Momo* & - & $17.6350^{\circ} \mathrm{S}$ & $179.2806^{\circ} \mathrm{W}$ \\
213 & Thakau Nokeva*a & - & $17.793^{\circ} \mathrm{S}$ & $178.6128^{\circ} \mathrm{W}$ \\
214 & Thakau Lasemawara*a & Thakau Lesemarawa & $17.7967^{\circ} \mathrm{S}$ & $178.6654^{\circ} \mathrm{W}$ \\
215 & Thakau Lekaleka*a & - & $17.6165^{\circ} \mathrm{S}$ & $178.3944^{\circ} \mathrm{W}$ \\
216 & Thakau Motu*a & - & $18.6712^{\circ} \mathrm{S}$ & $178.7222^{\circ} \mathrm{W}$ \\
217 & Thakau Vuite*a & - & $18.6810^{\circ} \mathrm{S}$ & $179.5700^{\circ} \mathrm{W}$ \\
218 & Navatu Reef*g & Tova Reef & $18.8819^{\circ} \mathrm{S}$ & $178.3927^{\circ} \mathrm{W}$ \\
219 & Thakau Levu*a & - & $20.7432^{\circ} \mathrm{S}$ & $178.8866^{\circ} \mathrm{W}$ \\
220 & Vuata Vatoa*g $^{\mathrm{a}}$ & - &
\end{tabular}

${ }^{\mathrm{a}}$ After Agassiz (1899), Davis (1928)

${ }^{\mathrm{b}}$ Island area $\approx 2.4 \%$ of rim

${ }^{\mathrm{c}}$ After Nunn (1987)

${ }^{\mathrm{d}}$ After Bryan (1953)

${ }^{\mathrm{e}}$ Islands $\approx 8.3 \%$ of rim area

${ }^{\mathrm{f}}$ Islands $\approx 2.6 \%$ of rim area

$\mathrm{g}$ After Spalding et al. (2001)

Bryan's (1953) list of 13 atolls in the New Caledonia region is reduced in Table A.11 to six. Huon (221) and Surprise (222) are the two large atolls that comprise part of the Entrecasteaux reef complex north of New Caledonia. There are several smaller atoll-like structures or banks associated with them (see bathymetry in Garrigue et al., 2000) that are not listed separately, consistent with treatment by Bryan (1953). Beautemps-Beaupre (224) is considered by Andréfouët et al. (2009) a bank rather than an atoll, although Chevalier (1973) described it as a submerged "half atoll." It is an atoll reef in the present list. Ouvéa (225) is partially uplifted on the eastern side (lagoon otherwise open) and is included. Chesterfield (223) and Bellona (226) atolls are large platforms supported by five guyots. They are capped with intertidal reefs on their western and southern flanks, and are drowned on the eastern margin (Andréfouët et al., 2009). Bryan subdivided the Chesterfield and Bellona reef complexes into five atolls. Petrie Reef, also listed by Bryan (1953), is a submerged oceanic bank southeast of Surprise Atoll and is not included here. 
Table A.11. Atolls of New Caledonia. An asterisk (*) indicates an atoll reef. Chart reference NGA 602.

\begin{tabular}{rlll} 
Atoll No. & Atoll Name & Latitude & Longitude \\
\hline 221 & Huon $^{*}$ & $18.1031^{\circ} \mathrm{S}$ & $162.8905^{\circ} \mathrm{E}$ \\
222 & Surprise $^{\mathrm{a}}$ & $18.4121^{\circ} \mathrm{S}$ & $163.1109^{\circ} \mathrm{E}$ \\
223 & Chesterfield Atoll* $^{*}$ & $19.2865^{\circ} \mathrm{S}$ & $158.6077^{\circ} \mathrm{E}$ \\
224 & Beautemps-Beaupre* & $20.3455^{\circ} \mathrm{S}$ & $166.1691^{\circ} \mathrm{E}$ \\
225 & Ouvéa & $20.5686^{\circ} \mathrm{S}$ & $166.4243^{\circ} \mathrm{E}$ \\
226 & Bellona Atoll* & $21.1560^{\circ} \mathrm{S}$ & $158.9917^{\circ} \mathrm{E}$ \\
\hline
\end{tabular}

${ }^{\mathrm{a}}$ Islands and cays $\approx 6 \%$ of rim

For Australia, Bryan (1953) lists 14 atolls in the Great Barrier Reef Province, and Spalding et al. (2001) refer to many of them as such. However, Willis, Coringa, Tresgrosse and Lihou are regarded as bank reefs (Orme, 1977; Guilcher, 1988); only Lihou (229), which has a well-defined northern and eastern rim (per chart INT 602), is included here. Holmes Reefs (228) are twin atoll reefs added to the list. Bryan (1953) referred to Middleton Reef (237) and Elizabeth Reef (238) as sunken (atoll reefs) and did not include them. Bryan's (1953) list of fourteen Australian atolls is thus reduced to twelve in Table A.12, ten of which are atoll reefs. All project from oceanic plateaus 1000-3000 m deep, and are at varying distances from the Great Barrier Reef on the Queensland continental shelf.

Table A.12. Atolls of Australia (Pacific Coast). An asterisk $\left(^{*}\right)$ indicates an atoll reef. Chart reference: NGA 602.

\begin{tabular}{rlll} 
Atoll No. & Atoll Name & Latitude & Longitude \\
\hline 227 & Osprey Reef* & $13.9110^{\circ} \mathrm{S}$ & $146.6319^{\circ} \mathrm{E}$ \\
228 & Holmes Reefs* & $16.4582^{\circ} \mathrm{S}$ & $147.9400^{\circ} \mathrm{E}$ \\
229 & Lihou Reef & $17.3929^{\circ} \mathrm{S}$ & $152.6626^{\circ} \mathrm{E}$ \\
230 & Mellish Reef* $^{*}$ & $17.3935^{\circ} \mathrm{S}$ & $155.8697^{\circ} \mathrm{E}$ \\
231 & Marion Reef* $^{*}$ & $19.1133^{\circ} \mathrm{S}$ & $152.2913^{\circ} \mathrm{E}$ \\
232 & Frederick Reef* $^{*}$ & $20.9440^{\circ} \mathrm{S}$ & $154.3798^{\circ} \mathrm{E}$ \\
233 & Kenn Reefs* $^{*}$ & $21.2196^{\circ} \mathrm{S}$ & $155.7580^{\circ} \mathrm{E}$ \\
234 & Saumarez Reef* & $21.8320^{\circ} \mathrm{S}$ & $153.6425^{\circ} \mathrm{E}$ \\
235 & Wreck Reef* $^{*}$ & $22.1891^{\circ} \mathrm{S}$ & $155.3322^{\circ} \mathrm{E}$ \\
236 & Cato Reef $^{\text {a }}$ & $23.2213^{\circ} \mathrm{S}$ & $155.5274^{\circ} \mathrm{E}$ \\
237 & Middleton Reef* & $29.4766^{\circ} \mathrm{S}$ & $159.0845^{\circ} \mathrm{E}$ \\
238 & Elizabeth Reef* & $29.9476^{\circ} \mathrm{S}$ & $159.0837^{\circ} \mathrm{E}$ \\
\hline${ }^{a}$ Island $\approx 7.7 \%$ of rim area (by ImageJ from chart-see \\
"Methods”)
\end{tabular}

Bryan's (1953) total for the Caroline Islands-less Mapia, which Bryan listed under Caroline Islands but I have moved to Indonesia (see Table A.8)—is 39, compared with 34 here (Table A.13).East Fayu, Gaferut, Merir, Nama, Pulo Anna, Satawal, Sonsorol and Tobi as reported by Bryan (1953) are confirmed here as having no lagoon (table reefs), and Ngeruangl Reef (Pulau) is submerged. None of these are included in this list.

Elongated Elato Atoll (249) is connected to Toas Atoll at a depth of $20 \mathrm{~m}$ (Wiens, 1962); the two are considered here as one. West Fayu, Puluwat, and Pulusuk (251-253) represent the emergent ends of much larger submerged atolls. Minto (264) is an atoll reef not included by Bryan (1953). Nomwin and Murilo (256 and 257, respectively) and Satawan, Lukunor and Etal (261-263) were listed previously as one 
group, but they are separated by depths of at least $300 \mathrm{~m}$ and are thus listed individually here. The area enclosed by Ngatik's (267) rim is $\sim 55 \mathrm{~km}^{2}$, but despite its small size the lagoon is up to $159 \mathrm{~m}$ deep (Purdy and Winterer, 2001) and may be the deepest of any atoll.

Table A.13. Atolls of the Caroline Islands. Atolls are listed west to east. An asterisk (*) indicates an atoll reef. A dagger $(\dagger)$ indicates a closed lagoon.

\begin{tabular}{|c|c|c|c|c|}
\hline Atoll No. & Atoll Name & Alternative Name & Latitude & Longitude \\
\hline 239 & Helen Reef* & - & $2.8932^{\circ} \mathrm{N}$ & $131.7843^{\circ} \mathrm{E}$ \\
\hline 240 & Kayangel & - & $8.0727^{\circ} \mathrm{N}$ & $134.7054^{\circ} \mathrm{E}$ \\
\hline 241 & Ngulu* & - & $8.4507^{\circ} \mathrm{N}$ & $137.4544^{\circ} \mathrm{E}$ \\
\hline 242 & Ulithi & - & $9.9550^{\circ} \mathrm{N}$ & $139.6495^{\circ} \mathrm{E}$ \\
\hline 243 & Sorol & - & $8.1452^{\circ} \mathrm{N}$ & $140.3724^{\circ} \mathrm{E}$ \\
\hline 244 & Eauripik*a & - & $6.6899^{\circ} \mathrm{N}$ & $143.0416^{\circ} \mathrm{E}$ \\
\hline 245 & Woleai & - & $7.3462^{\circ} \mathrm{N}$ & $143.8652^{\circ} \mathrm{E}$ \\
\hline 246 & Ifalik & Ifaluk & $7.2508^{\circ} \mathrm{N}$ & $144.4462^{\circ} \mathrm{E}$ \\
\hline 247 & Faraulep & - & $8.5910^{\circ} \mathrm{N}$ & $144.5096^{\circ} \mathrm{E}$ \\
\hline 248 & Olimarao & - & $7.6901^{\circ} \mathrm{N}$ & $145.8716^{\circ} \mathrm{E}$ \\
\hline 249 & Elato Atolls ${ }^{\mathrm{b}}$ & - & $7.4406^{\circ} \mathrm{N}$ & $146.1477^{\circ} \mathrm{E}$ \\
\hline 250 & Lamotrek $^{\mathrm{C}}$ & - & $7.4921^{\circ} \mathrm{N}$ & $146.3187^{\circ} \mathrm{E}$ \\
\hline 251 & West Fayu* & - & $8.0743^{\circ} \mathrm{N}$ & $146.7162^{\circ} \mathrm{E}$ \\
\hline 252 & Puluwat & - & $7.3592^{\circ} \mathrm{N}$ & $149.1893^{\circ} \mathrm{E}$ \\
\hline 253 & Pulusuk $^{\dagger d}$ & - & $6.6915^{\circ} \mathrm{N}$ & $149.3024^{\circ} \mathrm{E}$ \\
\hline 254 & Namonuito & Weito & $8.6810^{\circ} \mathrm{N}$ & $150.3550^{\circ} \mathrm{E}$ \\
\hline 255 & Pulap & - & $7.5901^{\circ} \mathrm{N}$ & $149.4220^{\circ} \mathrm{E}$ \\
\hline 256 & Nomwin*e & - & $8.5345^{\circ} \mathrm{N}$ & $151.7724^{\circ} \mathrm{E}$ \\
\hline 257 & Murilo* & - & $8.6790^{\circ} \mathrm{N}$ & $152.2321^{\circ} \mathrm{E}$ \\
\hline 258 & Kuop* & - & $7.0496^{\circ} \mathrm{N}$ & $151.9280^{\circ} \mathrm{E}$ \\
\hline 259 & Losap*f $^{f}$ & - & $6.8789^{\circ} \mathrm{N}$ & $152.6969^{\circ} \mathrm{E}$ \\
\hline 260 & Namoluk $^{\dagger}$ & - & $5.9137^{\circ} \mathrm{N}$ & $153.1406^{\circ} \mathrm{E}$ \\
\hline 261 & Satawan & - & $5.3944^{\circ} \mathrm{N}$ & $153.6206^{\circ} \mathrm{E}$ \\
\hline 262 & Lukunor & - & $5.5185^{\circ} \mathrm{N}$ & $153.7530^{\circ} \mathrm{E}$ \\
\hline 263 & Etal & - & $5.5903^{\circ} \mathrm{N}$ & $153.5672^{\circ} \mathrm{E}$ \\
\hline 264 & Minto Reef* & - & $8.1542^{\circ} \mathrm{N}$ & $154.2883^{\circ} \mathrm{E}$ \\
\hline 265 & Kapingamarangi & - & $1.0650^{\circ} \mathrm{N}$ & $154.7722^{\circ} \mathrm{E}$ \\
\hline 266 & Nukuoro $^{\dagger}$ & - & $3.8478^{\circ} \mathrm{N}$ & $154.9414^{\circ} \mathrm{E}$ \\
\hline 267 & Ngatik & Sapwuahfik & $5.8105^{\circ} \mathrm{N}$ & $157.2732^{\circ} \mathrm{E}$ \\
\hline 268 & Oraluk* & - & $7.5134^{\circ} \mathrm{N}$ & $155.3036^{\circ} \mathrm{E}$ \\
\hline 269 & Pakin $^{\dagger}$ & - & $7.0565^{\circ} \mathrm{N}$ & $157.8079^{\circ} \mathrm{E}$ \\
\hline 270 & Ant & And & $6.7768^{\circ} \mathrm{N}$ & $157.9598^{\circ} \mathrm{E}$ \\
\hline 271 & Mwoakilloa $^{\dagger}$ & Mokil & $6.6799^{\circ} \mathrm{N}$ & $159.7566^{\circ} \mathrm{E}$ \\
\hline 272 & Pingelap $^{\dagger}$ & - & $6.2174^{\circ} \mathrm{N}$ & $160.7024^{\circ} \mathrm{E}$ \\
\hline \multicolumn{5}{|c|}{${ }^{\mathrm{a}}$ Islands $\approx 1.6 \%$ of rim area } \\
\hline \multicolumn{5}{|c|}{${ }^{\mathrm{b}}$ Islands $\approx 5.1 \%$ (north) and $6.3 \%$ (south) of rim } \\
\hline \multicolumn{5}{|c|}{${ }^{\mathrm{c}}$ Island areas $(3) \approx 6.5 \%$ of rim } \\
\hline \multicolumn{5}{|c|}{${ }^{\mathrm{d}}$ Brackish lagoon } \\
\hline \multicolumn{5}{|c|}{${ }^{\mathrm{e}}$ Island areas $\approx 2.6 \%$ of rim } \\
\hline \multicolumn{5}{|c|}{${ }^{\mathrm{f}}$ Island areas $\approx 3.5 \%$ of rim } \\
\hline
\end{tabular}


Two atolls are found in an isolated portion of the Pacific northeast of the Caroline Islands and north of the Marshall Islands (Table A.14). The lagoon on Wake Atoll (274) has been extensively modified by construction (Lobel and Lobel, 2008). Marcus Island, which has no lagoon, is not included in this list.

The Marshall Islands encompasses 29 atolls divided between the Ralik and Ratak chains (Table A.15). Lae (284) features a channel in its rim that is $\sim 4 \mathrm{~m}$ deep (see supplementary material online). Utrik (293) likewise has a 4-5 $\mathrm{m}$ deep channel in its rim that is navigable with difficulty (NGA, 2014b). Mili (303) is attached to smaller Narikrik Atoll at its southeast by a shallow (6 m deep) submarine ridge (Wiens, 1962); these two are considered here as one structure.

Table A.14. Atolls of the isolated Pacific. An asterisk (*) indicates an atoll reef.

\begin{tabular}{rlccl} 
Atoll No. & Atoll Name & Alternative Name & Latitude & Longitude \\
\hline 273 & Parece Vela* & Okinotori & $20.4215^{\circ} \mathrm{N}$ & $136.0919^{\circ} \mathrm{E}$ \\
274 & Wake & - & $19.2977^{\circ} \mathrm{N}$ & $166.6262^{\circ} \mathrm{E}$ \\
\hline
\end{tabular}

Table A.15. Atolls of the Marshall Islands. Atolls are listed north to south within each chain grouping. An asterisk (*) indicates an atoll reef. A dagger ( $\dagger$ ) indicates a closed lagoon.

\begin{tabular}{|c|c|c|c|c|}
\hline Atoll No. & Atoll Name & Alternative Name(s) & Latitude & Longitude \\
\hline \multicolumn{5}{|c|}{ Ralik Chain } \\
\hline 275 & Bikini & - & $11.5904^{\circ} \mathrm{N}$ & $165.3822^{\circ} \mathrm{E}$ \\
\hline 276 & Enewetak & - & $11.4948^{\circ} \mathrm{N}$ & $162.2244^{\circ} \mathrm{E}$ \\
\hline 277 & Rongelap & - & $11.3333^{\circ} \mathrm{N}$ & $166.8131^{\circ} \mathrm{E}$ \\
\hline 278 & Rongerik*a & - & $11.3565^{\circ} \mathrm{N}$ & $167.4482^{\circ} \mathrm{E}$ \\
\hline 279 & Ailinginae & - & $11.1429^{\circ} \mathrm{N}$ & $166.4339^{\circ} \mathrm{E}$ \\
\hline 280 & Wotho & - & $10.1046^{\circ} \mathrm{N}$ & $165.9733^{\circ} \mathrm{E}$ \\
\hline 281 & Ujelang & - & $9.8237^{\circ} \mathrm{N}$ & $160.8952^{\circ} \mathrm{E}$ \\
\hline 282 & Kwajalein & - & $9.1876^{\circ} \mathrm{N}$ & $167.4552^{\circ} \mathrm{E}$ \\
\hline 283 & $\mathrm{Ujae}^{* \mathrm{~b}}$ & - & $9.0679^{\circ} \mathrm{N}$ & $165.6367^{\circ} \mathrm{E}$ \\
\hline 284 & Lae & - & $8.9374^{\circ} \mathrm{N}$ & $166.2406^{\circ} \mathrm{E}$ \\
\hline 285 & $\mathrm{Lib}^{\dagger c}$ & - & $8.3132^{\circ} \mathrm{N}$ & $167.3805^{\circ} \mathrm{E}$ \\
\hline 286 & $\mathrm{Namu}^{\mathrm{d}}$ & - & $7.9867^{\circ} \mathrm{N}$ & $168.1679^{\circ} \mathrm{E}$ \\
\hline 287 & Ailinglaplap & - & $7.3947^{\circ} \mathrm{N}$ & $168.7634^{\circ} \mathrm{E}$ \\
\hline 288 & Jaluit & - & $6.0064^{\circ} \mathrm{N}$ & $169.5537^{\circ} \mathrm{E}$ \\
\hline 289 & Namorik $^{\dagger}$ & - & $5.6137^{\circ} \mathrm{N}$ & $168.1155^{\circ} \mathrm{E}$ \\
\hline 290 & Ebon & - & $4.6349^{\circ} \mathrm{N}$ & $168.7192^{\circ} \mathrm{E}$ \\
\hline \multicolumn{5}{|c|}{ Ratak Chain } \\
\hline 291 & Bokaak $^{\dagger}$ & Taongi & $14.6559^{\circ} \mathrm{N}$ & $168.9733^{\circ} \mathrm{E}$ \\
\hline 292 & Bikar*e & - & $12.2439^{\circ} \mathrm{N}$ & $170.1074^{\circ} \mathrm{E}$ \\
\hline 293 & Utrik & Utirik & $11.2458^{\circ} \mathrm{N}$ & $169.7902^{\circ} \mathrm{E}$ \\
\hline 294 & Taka*f & Toka, Toke & $11.1454^{\circ} \mathrm{N}$ & $169.6238^{\circ} \mathrm{E}$ \\
\hline 295 & Ailuk & - & $10.3134^{\circ} \mathrm{N}$ & $169.9373^{\circ} \mathrm{E}$ \\
\hline 296 & Likiep & - & $9.8970^{\circ} \mathrm{N}$ & $169.1366^{\circ} \mathrm{E}$ \\
\hline 297 & Wotje & - & $9.4385^{\circ} \mathrm{N}$ & $170.0167^{\circ} \mathrm{E}$ \\
\hline 298 & Erikub*g & - & $9.1420^{\circ} \mathrm{N}$ & $170.0205^{\circ} \mathrm{E}$ \\
\hline 299 & Maloelap & - & $8.7375^{\circ} \mathrm{N}$ & $\begin{array}{l}171.0411^{\circ} \mathrm{E} \\
\text { (continued) }^{2}\end{array}$ \\
\hline
\end{tabular}


Table A.15. Atolls of the Marshall Islands. (continued)

\begin{tabular}{rlccc}
\hline Atoll No. & Atoll Name & Alternative Name(s) & Latitude & Longitude \\
\hline 300 & Aur & - & $8.2557^{\circ} \mathrm{N}$ & $171.0935^{\circ} \mathrm{E}$ \\
301 & Majuro & - & $7.1137^{\circ} \mathrm{N}$ & $171.1993^{\circ} \mathrm{E}$ \\
302 & Arno & - & $7.0611^{\circ} \mathrm{N}$ & $171.6631^{\circ} \mathrm{E}$ \\
303 Mili & - & $6.1312^{\circ} \mathrm{N}$ & $171.9422^{\circ} \mathrm{E}$ \\
\hline${ }^{\mathrm{a}}$ Islands $\approx 3.5 \%$ of rim & & \\
b Island area $\approx 4.0 \%$ of rim & & \\
${ }^{\mathrm{c}}$ Brackish lagoon & & \\
${ }^{\mathrm{d}}$ Island areas $\approx 6.0 \%$ of rim & & \\
$\mathrm{e}$ Island areas $\approx 1.9 \%$ of rim & & \\
f Island areas $\approx 1.8 \%$ of rim & & \\
g Island areas $\approx 4.5 \%$ of rim & & &
\end{tabular}

Twelve atolls are found in the Gilbert Islands (Table A.16). Marakei's (305) and Nikunau's (313) lagoons are closed and brackish (Table B.1; Tebano, 2008). Conversely, Wester et al. (1992) reports that Nikunau has a marine character due to exchange of marine water through the limestone platform's fissures and caves. Nikunau's lagoon is much reduced in proportion to the island.

For Tuvalu, islands listed by Bryan (1953) as atolls include three with reduced, largely or completely landlocked lagoons with varying degrees of mangrove development (Table B.1; Woodroffe, 1987): Nanumea, Niutao and Nanumanga (316-318). Nanumea's lagoon is essentially closed but is altered by an artificial boat channel $450 \mathrm{~m}$ long, $18 \mathrm{~m}$ wide and $2 \mathrm{~m}$ deep (Xue, 2005). There is no salinity data available, but presence of holothurians, Acanthaster and corals suggests that sections of the lagoon are euhaline (Job and Ceccarelli, 2012). Niutao and Nanumanga are closed but exchange water through porous limestone and retain the marine character of their lagoons (Wester et al., 1992). Krüger (2008), in contrast, reports that these are brackish lagoons. Niulakita's lagoon is filled and thus it is not included among Tuvalu’s atolls (Table A.17).

Table A.16. Atolls of the Gilbert Islands, Kiribati. A dagger $(\dagger)$ indicates a closed lagoon.

\begin{tabular}{|c|c|c|c|c|}
\hline Atoll No. & Atoll Name & Alternative Name & Latitude & Longitude \\
\hline 304 & Butaritari & Makin & $3.1520^{\circ} \mathrm{N}$ & $172.8311^{\circ} \mathrm{E}$ \\
\hline 305 & Marakei $^{\dagger}$ & - & $2.0014^{\circ} \mathrm{N}$ & $173.2765^{\circ} \mathrm{E}$ \\
\hline 306 & Abiang & - & $1.8569^{\circ} \mathrm{N}$ & $172.9472^{\circ} \mathrm{E}$ \\
\hline 307 & Tarawa & - & $1.4387^{\circ} \mathrm{N}$ & $172.9878^{\circ} \mathrm{E}$ \\
\hline 308 & Maiana & - & $0.9321^{\circ} \mathrm{N}$ & $173.0036^{\circ} \mathrm{E}$ \\
\hline 309 & Abemama & - & $0.3927^{\circ} \mathrm{N}$ & $173.8657^{\circ} \mathrm{E}$ \\
\hline 310 & Aranuka & - & $0.1659^{\circ} \mathrm{N}$ & $173.6088^{\circ} \mathrm{E}$ \\
\hline 311 & Nonouti & - & $0.6534^{\circ} \mathrm{S}$ & $174.3477^{\circ} \mathrm{E}$ \\
\hline 312 & Beru & - & $1.3215^{\circ} \mathrm{S}$ & $175.9784^{\circ} \mathrm{E}$ \\
\hline 313 & Nikunau $^{\dagger}$ & - & $1.3475^{\circ} \mathrm{S}$ & $176.4512^{\circ} \mathrm{E}$ \\
\hline 314 & Tabituea & - & $1.4089^{\circ} \mathrm{S}$ & $174.8694^{\circ} \mathrm{E}$ \\
\hline 315 & Onotoa & - & $1.8776^{\circ} \mathrm{S}$ & $175.5596^{\circ} \mathrm{E}$ \\
\hline
\end{tabular}


Table A.17. Atolls of Tuvalu (formerly Ellice Islands). A dagger $(\dagger)$ indicates a closed lagoon.

\begin{tabular}{rlll} 
Atoll No. & Atoll Name & Latitude & Longitude \\
\hline 316 & Nanumea $^{\dagger}$ & $5.6612^{\circ} \mathrm{S}$ & $176.1035^{\circ} \mathrm{E}$ \\
317 & Niutao $^{\dagger}$ & $6.1087^{\circ} \mathrm{S}$ & $177.3418^{\circ} \mathrm{E}$ \\
318 & Nanumanga $^{\dagger}$ & $6.2885^{\circ} \mathrm{S}$ & $176.3202^{\circ} \mathrm{E}$ \\
319 & Nui $^{\dagger}$ & $7.2258^{\circ} \mathrm{S}$ & $177.1546^{\circ} \mathrm{E}$ \\
320 & Vaitupu $^{\dagger}$ & $7.2792^{\circ} \mathrm{S}$ & $178.6782^{\circ} \mathrm{E}$ \\
321 & Nukufetau $^{\circ}$ & $7.9942^{\circ} \mathrm{S}$ & $178.3778^{\circ} \mathrm{E}$ \\
322 & Funafuti $_{32}$ & $8.5155^{\circ} \mathrm{S}$ & $179.1130^{\circ} \mathrm{E}$ \\
323 & Nukulaelae $^{\dagger}$ & $9.3872^{\circ} \mathrm{S}$ & $179.8424^{\circ} \mathrm{E}$ \\
\hline
\end{tabular}

\section{EASTERN PACIFIC OCEAN 117 Atolls}

There are 117 atolls in the eastern Pacific Ocean, an area including Hawaii, the central Pacific, the Cook Islands, and French Polynesia and the eastern Pacific.

In Hawaii, Laysan (327) is elevated $12 \mathrm{~m}$ due to glacioeustatic sea level changes (Schlanger and Gillett, 1976); it is now a hypersaline lagoon (Table B.1; Caspers 1981; Athens et al. 2007). Lisiansky lacks a lagoon. Both were listed by Bryan (1953), but the latter is not included here among Hawaiian atolls (Table A.18). French Frigate Shoals (328) is an atoll reef and was not listed by Bryan.

In the central Pacific, Johnston (329) is an atypical atoll structure with an emergent reef on the leeward side, possibly due to tilting (Maragos et al., 2008a). It was formed during World War II by dredging (Lobel and Lobel, 2008). Kingman (330) is an atoll reef 5-7 m below surface on the east and 10-15 $\mathrm{m}$ to the west (Maragos et al., 2008a; Gardner et al., 2014).

In the Line Islands, Palmyra's (331) lagoons, which were heavily modified by dredging during World War II, become dysoxic/anoxic below $30 \mathrm{~m}$, where their waters also develop high sulfide levels (Maragos et al., 2008b; Gardner et al., 2011). Palmyra's lagoon was closed until opened by an artificial channel in its southwest corner. Teraina, Malden, and Starbuck (332, 335, and 336, respectively) feature isolated, closed lagoons with altered salinity (Table B.1).

Vostok and Flint (Line Islands) as well as Jarvis, Howland and Baker islands in the central Pacific have no lagoons. None of these are included in the listing of central Pacific atolls in Table A.19; all were listed by Bryan (1953).

In the Phoenix Islands, four atolls' lagoons are reduced and reportedly brackish or hypersaline: Enderbury (339), Birnie (340), Rawaki (342), and Manra (343). McKean’s (341) lagoon is partially filled with mud and guano and is intertidal (Dana, 1979). In Samoa, Olosega's (349) lagoon is brackish (Table B.1). Bryan (1953) excludes four atoll reefs listed in Table A.19: Rose, Beveridge Reef, and Minerva Reefs (350-352b). Minerva Reefs (352a/b) are Minerva North, a circular atoll about 6 km diameter, and Minerva South, a figure-eight atoll about $11 \mathrm{~km}$ in diameter (Davis, 1928); these are tentatively treated as one pending bathymetric report. 
Table A.18. Atolls of Hawaii. An asterisk $(*)$ indicates an atoll reef. A dagger $(\dagger)$ indicates a closed lagoon.

\begin{tabular}{rlll} 
Atoll No. & Atoll Name & Latitude & Longitude \\
\hline 324 & Kure* & $28.4226^{\circ} \mathrm{N}$ & $178.3294^{\circ} \mathrm{W}$ \\
325 & Midway & $28.2370^{\circ} \mathrm{N}$ & $177.3711^{\circ} \mathrm{W}$ \\
326 & Pearl and Hermes Reef* $^{*}$ & $27.8730^{\circ} \mathrm{N}$ & $175.8354^{\circ} \mathrm{W}$ \\
327 & Laysan $^{\dagger}$ & $25.7695^{\circ} \mathrm{N}$ & $171.7328^{\circ} \mathrm{W}$ \\
328 & French Frigate Shoals* $^{*}$ & $23.7551^{\circ} \mathrm{N}$ & $166.2096^{\circ} \mathrm{W}$ \\
\hline
\end{tabular}

Table A.19. Atolls of the Central Pacific. An asterisk (*) indicates an atoll reef. A dagger $(\dagger)$ indicates a closed lagoon.

\begin{tabular}{|c|c|c|c|c|}
\hline Atoll No. & Atoll Name & Alternative Name & Latitude & Longitude \\
\hline 329 & Johnston $^{\mathrm{a}}$ & - & $16.7450^{\circ} \mathrm{N}$ & $169.5130^{\circ} \mathrm{W}$ \\
\hline 330 & Kingman Reef*a & - & $6.4068^{\circ} \mathrm{N}$ & $162.3995^{\circ} \mathrm{W}$ \\
\hline 331 & Palmyra ${ }^{\dagger a}$ & - & $5.8839^{\circ} \mathrm{N}$ & $162.0834^{\circ} \mathrm{W}$ \\
\hline \multicolumn{5}{|c|}{ Line Islands, Kiribati } \\
\hline 332 & Teraina $^{\dagger}$ & Washington & $4.6839^{\circ} \mathrm{N}$ & $160.3803^{\circ} \mathrm{W}$ \\
\hline 333 & Tabuaeran & Fanning & $3.8637^{\circ} \mathrm{N}$ & $159.3236^{\circ} \mathrm{W}$ \\
\hline 334 & Kiritimati $^{\dagger}$ & Christmas & $1.8708^{\circ} \mathrm{N}$ & $157.4141^{\circ} \mathrm{W}$ \\
\hline 335 & Malden $^{\dagger}$ & - & $4.0221^{\circ} \mathrm{S}$ & $154.9250^{\circ} \mathrm{W}$ \\
\hline 336 & Starbuck $^{\dagger}$ & - & $5.6405^{\circ} \mathrm{S}$ & $155.8776^{\circ} \mathrm{W}$ \\
\hline 337 & Caroline $^{\dagger}$ & Millennium & $9.9648^{\circ} \mathrm{S}$ & $150.2077^{\circ} \mathrm{W}$ \\
\hline \multicolumn{5}{|c|}{ Phoenix Islands, Kiribati } \\
\hline 338 & Kanton & Aba-Riringa & $2.8140^{\circ} \mathrm{S}$ & $171.6735^{\circ} \mathrm{W}$ \\
\hline 339 & Enderbury $^{\dagger}$ & - & $3.1263^{\circ} \mathrm{S}$ & $171.0865^{\circ} \mathrm{W}$ \\
\hline 340 & Birnie $^{\dagger}$ & - & $3.5847^{\circ} \mathrm{S}$ & $171.5169^{\circ} \mathrm{W}$ \\
\hline 341 & McKean $^{\dagger}$ & - & $3.5954^{\circ} \mathrm{S}$ & $174.1229^{\circ} \mathrm{W}$ \\
\hline 342 & Rawaki $^{\dagger}$ & - & $3.7217^{\circ} \mathrm{S}$ & $170.7118^{\circ} \mathrm{W}$ \\
\hline 343 & Manra $^{\dagger}$ & Sydney & $4.4556^{\circ} \mathrm{S}$ & $171.2444^{\circ} \mathrm{W}$ \\
\hline 344 & Orona $^{\dagger}$ & Hull & $4.5118^{\circ} \mathrm{S}$ & $172.1798^{\circ} \mathrm{W}$ \\
\hline 345 & Nikumaroro $^{\dagger}$ & Gardner & $4.6764^{\circ} \mathrm{S}$ & $174.5185^{\circ} \mathrm{W}$ \\
\hline \multicolumn{5}{|c|}{ Tokelau Islands, New Zealand } \\
\hline 346 & $\mathrm{Atafu}^{\dagger}$ & - & $8.5602^{\circ} \mathrm{S}$ & $172.4929^{\circ} \mathrm{W}$ \\
\hline 347 & Nikunonu $^{\dagger}$ & - & $9.1687^{\circ} \mathrm{S}$ & $171.8176^{\circ} \mathrm{W}$ \\
\hline 348 & Fakaofo $^{\dagger}$ & - & $9.3736^{\circ} \mathrm{S}$ & $171.2162^{\circ} \mathrm{W}$ \\
\hline \multicolumn{5}{|c|}{ Samoa } \\
\hline 349 & Olosega $^{\dagger}$ & Swains & $11.0555^{\circ} \mathrm{S}$ & $171.0780^{\circ} \mathrm{W}$ \\
\hline 350 & Rose*b & Motu-o- Manu & $14.5452^{\circ} \mathrm{S}$ & $168.1554^{\circ} \mathrm{W}$ \\
\hline \multicolumn{5}{|c|}{ Isolated Southwestern Pacific } \\
\hline 351 & Beveridge Reef* & - & $20.0039^{\circ} \mathrm{S}$ & $167.7589^{\circ} \mathrm{W}$ \\
\hline 352a & Minerva Reef (north)* & - & $23.6413^{\circ} \mathrm{S}$ & $178.9133^{\circ} \mathrm{W}$ \\
\hline $352 b$ & Minerva Reef (south)* & - & $23.9371^{\circ} \mathrm{S}$ & $179.1100^{\circ} \mathrm{W}$ \\
\hline
\end{tabular}

${ }^{\mathrm{a}}$ U.S. territories; Kingman and Palmyra form the northern portion of the Line Island group.

${ }^{\mathrm{b}}$ Island area $\approx 1.8 \%$ of rim area 
Bryan's list includes nine entries for the Cook Islands. Nassau Island has a swamp-filled depression in the center (Wester et al., 1992), and Takutea has no lagoon. Neither is included in Table A.20, nor is Aitutaki, an almost-atoll (Stoddard, 1975). Pukapuka (356) has a small channel (apparently not navigable) through the northwest rim and is closed. The rim surrounding Manuae (359) lacks a channel and is here categorized as a closed atoll, even though the rim (excluding the portion developed as islands) appears to be subsurface. With the exception of Manuae, other reef islands in the southern Cook group are uplifted in response to nearby volcanic Rarotonga (Woodroffe, 1991) and are not included.

Table A.20. Atolls of the Cook Islands. A dagger $(\dagger)$ indicates a closed lagoon.

\begin{tabular}{rllrl} 
Atoll No. & Atoll Name & Alternative Name & Latitude & Longitude \\
\hline 353 & Penrhyn & Tongareva & $8.9993^{\circ} \mathrm{S}$ & $157.9715^{\circ} \mathrm{W}$ \\
354 & Rakahanga $^{\dagger}$ & Reirson & $10.0165^{\circ} \mathrm{S}$ & $161.0896^{\circ} \mathrm{W}$ \\
355 & Manahiki $^{\dagger}$ & Humphrey & $10.4259^{\circ} \mathrm{S}$ & $161.0007^{\circ} \mathrm{W}$ \\
356 & Pukapuka $^{\circ}$ & Danger & $10.8858^{\circ} \mathrm{S}$ & $165.8534^{\circ} \mathrm{W}$ \\
357 & Suwarrow $^{\dagger}$ & Anchorage & $13.2279^{\circ} \mathrm{S}$ & $163.1261^{\circ} \mathrm{W}$ \\
358 & Palmerston $^{\dagger}$ & Pamati & $18.0474^{\circ} \mathrm{S}$ & $163.1548^{\circ} \mathrm{W}$ \\
359 & Manuae $^{\dagger}$ & Hervey & $19.2697^{\circ} \mathrm{S}$ & $158.9441^{\circ} \mathrm{W}$ \\
\hline
\end{tabular}

There are 83 nominal atolls in French Polynesia, 76 of which are in the Tuamotu group. However, four of the Tuamotu islands are filled and no longer present a lagoon (Akiaki, Nukutavake, Tepoto Nord and Tikei), and Makatea is uplifted. These are not included in Table A.21. Therefore, despite literature with contrary numbers, there are 78 atolls with lagoons in French Polynesia (Salvat, 2009), including 71 in the Tuamotu Archipelago, 5 in the Society Islands, 1 in the Gambier group, and 1 in the Austral group, as listed here. Maupiti is an almost-atoll (Society group), as is Mangareva (Gambier group); these are not included. No satellite imagery was available for Moses Reef, Récif Lancaster or Récif President Thiers (Spalding, 2001:390). These reefs in the Austral Archipelago are also not included.

There are 53 atolls in French Polynesia with closed lagoons. Takapoto (370) and Taiaro (378) lagoons are modestly hypersaline; likewise, Niau's (386) lagoon is elevated, closed, somewhat brackish, and may develop reduced oxygen levels (Table B.1).

Table A.21. Atolls of French Polynesia. A dagger $(\dagger)$ indicates a closed lagoon. Atolls in the Tuamotu Islands are listed northwest to southeast by latitude.

\begin{tabular}{|c|c|c|c|c|}
\hline Atoll No. & Atoll Name & Alternative Name & Latitude & Longitude \\
\hline \multicolumn{5}{|c|}{ Society Islands } \\
\hline 360 & Motu One ${ }^{\dagger}$ & Belling-hausen & $15.8143^{\circ} \mathrm{S}$ & $154.5224^{\circ} \mathrm{W}$ \\
\hline 361 & Tupai $^{\dagger}$ & Motu Iti & $16.2623^{\circ} \mathrm{S}$ & $151.8165^{\circ} \mathrm{W}$ \\
\hline 362 & Manuae $^{\dagger}$ & Scilly & $16.5434^{\circ} \mathrm{S}$ & $154.6841^{\circ} \mathrm{W}$ \\
\hline 363 & Maupihaa & Mopelia & $16.8098^{\circ} \mathrm{S}$ & $153.9555^{\circ} \mathrm{W}$ \\
\hline 364 & Tetiaroa $^{\dagger}$ & - & $17.0070^{\circ} \mathrm{S}$ & $149.5602^{\circ} \mathrm{W}$ \\
\hline \multicolumn{5}{|c|}{ Austral Islands } \\
\hline 365 & \multicolumn{4}{|c|}{ Tuamotu Islands } \\
\hline 366 & Napuka $^{\dagger}$ & - & $14.1726^{\circ} \mathrm{S}$ & $141.2310^{\circ} \mathrm{W}$ \\
\hline 367 & Manihi & - & $14.4038^{\circ} \mathrm{S}$ & $145.9477^{\circ} \mathrm{W}$ \\
\hline 368 & Takaroa & - & $14.4496^{\circ} \mathrm{S}$ & $144.9694^{\circ} \mathrm{W}$ \\
\hline 369 & Ahe & - & $14.4784^{\circ} \mathrm{S}$ & $\begin{array}{r}146.3037^{\circ} \mathrm{W} \\
\text { (continued) }\end{array}$ \\
\hline
\end{tabular}


Table A.21. Atolls of French Polynesia. (continued)

\begin{tabular}{|c|c|c|c|c|}
\hline Atoll No. & Atoll Name & Alternative Name & Latitude & Longitude \\
\hline 370 & Takapoto $^{\dagger}$ & - & $14.6236^{\circ} \mathrm{S}$ & $145.2024^{\circ} \mathrm{W}$ \\
\hline 371 & Puka-Puka $^{\dagger}$ & - & $14.8176^{\circ} \mathrm{S}$ & $138.8167^{\circ} \mathrm{W}$ \\
\hline 372 & Mataiva $^{\dagger}$ & - & $14.8831^{\circ} \mathrm{S}$ & $148.6738^{\circ} \mathrm{W}$ \\
\hline 373 & Tikehau & - & $15.0031^{\circ} \mathrm{S}$ & $148.1738^{\circ} \mathrm{W}$ \\
\hline 374 & Rangiroa & - & $15.1138^{\circ} \mathrm{S}$ & $147.6486^{\circ} \mathrm{W}$ \\
\hline 375 & Arutua & - & $15.3217^{\circ} \mathrm{S}$ & $146.7420^{\circ} \mathrm{W}$ \\
\hline 376 & Apataki & - & $15.4527^{\circ} \mathrm{S}$ & $146.3248^{\circ} \mathrm{W}$ \\
\hline 377 & Aratika & - & $15.5392^{\circ} \mathrm{S}$ & $145.5294^{\circ} \mathrm{W}$ \\
\hline 378 & Taiaro $^{\dagger}$ & - & $15.7438^{\circ} \mathrm{S}$ & $144.6336^{\circ} \mathrm{W}$ \\
\hline 379 & Kaukura $^{\dagger}$ & - & $15.7563^{\circ} \mathrm{S}$ & $146.6987^{\circ} \mathrm{W}$ \\
\hline 380 & Takume $^{\dagger}$ & - & $15.8099^{\circ} \mathrm{S}$ & $142.2098^{\circ} \mathrm{W}$ \\
\hline 381 & Fangatau $^{\dagger}$ & - & $15.8262^{\circ} \mathrm{S}$ & $140.8618^{\circ} \mathrm{W}$ \\
\hline 382 & Kauehi & - & $15.8772^{\circ} \mathrm{S}$ & $145.1562^{\circ} \mathrm{W}$ \\
\hline 383 & Toau & - & $15.9070^{\circ} \mathrm{S}$ & $146.0233^{\circ} \mathrm{W}$ \\
\hline 384 & Fakahina $^{\dagger}$ & - & $15.9851^{\circ} \mathrm{S}$ & $140.1331^{\circ} \mathrm{W}$ \\
\hline 385 & Raroia & - & $16.0809^{\circ} \mathrm{S}$ & $142.4241^{\circ} \mathrm{W}$ \\
\hline 386 & $\mathrm{Niau}^{\dagger}$ & - & $16.1554^{\circ} \mathrm{S}$ & $146.3544^{\circ} \mathrm{W}$ \\
\hline 387 & Raraka & - & $16.1764^{\circ} \mathrm{S}$ & $144.8953^{\circ} \mathrm{W}$ \\
\hline 388 & Fakarava & - & $16.2928^{\circ} \mathrm{S}$ & $145.6084^{\circ} \mathrm{W}$ \\
\hline 389 & Taenga & - & $16.3574^{\circ} \mathrm{S}$ & $143.1398^{\circ} \mathrm{W}$ \\
\hline 390 & Katiu & - & $16.4236^{\circ} \mathrm{S}$ & $144.3601^{\circ} \mathrm{W}$ \\
\hline 391 & Rekareka $^{\dagger}$ & Tehuata & $16.8340^{\circ} \mathrm{S}$ & $141.9218^{\circ} \mathrm{W}$ \\
\hline 392 & Makemo & - & $16.6180^{\circ} \mathrm{S}$ & $143.6890^{\circ} \mathrm{W}$ \\
\hline 393 & Tuanake $^{\dagger}$ & - & $16.6531^{\circ} \mathrm{S}$ & $144.2148^{\circ} \mathrm{W}$ \\
\hline 394 & Nihiru $^{\dagger}$ & - & $16.6922^{\circ} \mathrm{S}$ & $142.8347^{\circ} \mathrm{W}$ \\
\hline 395 & $\mathrm{Hiti}^{\dagger}$ & - & $16.7277^{\circ} \mathrm{S}$ & $144.0955^{\circ} \mathrm{W}$ \\
\hline 396 & Faaite & - & $16.7506^{\circ} \mathrm{S}$ & $145.2421^{\circ} \mathrm{W}$ \\
\hline 397 & Tepoto Sud ${ }^{\dagger}$ & - & $16.8206^{\circ} \mathrm{S}$ & $144.2804^{\circ} \mathrm{W}$ \\
\hline 398 & Tahanea & - & $16.8646^{\circ} \mathrm{S}$ & $144.7778^{\circ} \mathrm{W}$ \\
\hline 399 & Martea $^{\dagger}$ & Marutea Nord & $17.0245^{\circ} \mathrm{S}$ & $143.1548^{\circ} \mathrm{W}$ \\
\hline 400 & Motutunga & - & $17.1036^{\circ} \mathrm{S}$ & $144.3686^{\circ} \mathrm{W}$ \\
\hline 401 & Tekokota $^{\dagger}$ & - & $17.3135^{\circ} \mathrm{S}$ & $142.5725^{\circ} \mathrm{W}$ \\
\hline 402 & Takatoto $^{\dagger}$ & - & $17.3416^{\circ} \mathrm{S}$ & $138.3967^{\circ} \mathrm{W}$ \\
\hline 403 & Tauere $^{\dagger}$ & - & $17.3772^{\circ} \mathrm{S}$ & $141.5060^{\circ} \mathrm{W}$ \\
\hline 404 & Anaa $^{\dagger}$ & - & $17.4134^{\circ} \mathrm{S}$ & $145.4918^{\circ} \mathrm{W}$ \\
\hline 405 & Haraiki & - & $17.4651^{\circ} \mathrm{S}$ & $143.4489^{\circ} \mathrm{W}$ \\
\hline 406 & Hikueru $^{\dagger}$ & - & $17.5884^{\circ} \mathrm{S}$ & $142.6158^{\circ} \mathrm{W}$ \\
\hline 407 & Amanu & - & $17.8076^{\circ} \mathrm{S}$ & $140.7621^{\circ} \mathrm{W}$ \\
\hline 408 & Reitoru $^{\dagger}$ & - & $17.8555^{\circ} \mathrm{S}$ & $143.0744^{\circ} \mathrm{W}$ \\
\hline 409 & Marokau $^{\dagger}$ & - & $18.0605^{\circ} \mathrm{S}$ & $142.2658^{\circ} \mathrm{W}$ \\
\hline 410 & Pukarua $^{\dagger}$ & Pukaruha & $18.3159^{\circ} \mathrm{S}$ & $137.0181^{\circ} \mathrm{W}$ \\
\hline 411 & Нао & - & $18.2471^{\circ} \mathrm{S}$ & $140.8738^{\circ} \mathrm{W}$ \\
\hline 412 & Ravahere $^{\dagger}$ & - & $18.2358^{\circ} \mathrm{S}$ & $142.1475^{\circ} \mathrm{W}$ \\
\hline 413 & $\operatorname{Reao}^{\dagger}$ & - & $18.5160^{\circ} \mathrm{S}$ & $136.3717^{\circ} \mathrm{W}$ \\
\hline 414 & Nengonengo & - & $18.7518^{\circ} \mathrm{S}$ & $141.8072^{\circ} \mathrm{W}$ \\
\hline 415 & Vahitahi $^{\dagger}$ & - & $18.7742^{\circ} \mathrm{S}$ & $138.8197^{\circ} \mathrm{W}$ \\
\hline 416 & Manuhangi $^{\dagger}$ & - & $19.2011^{\circ} \mathrm{S}$ & $141.2441^{\circ} \mathrm{W}$ \\
\hline 417 & Paraoa $^{\dagger}$ & - & $19.1365^{\circ} \mathrm{S}$ & $140.6900^{\circ} \mathrm{W}$ \\
\hline 418 & Vairaatea $^{\dagger}$ & - & $19.3491^{\circ} \mathrm{S}$ & $\begin{array}{r}139.2201^{\circ} \mathrm{W} \\
\text { (continued) }\end{array}$ \\
\hline
\end{tabular}


Table A.21. Atolls of French Polynesia. (continued)

\begin{tabular}{|c|c|c|c|c|}
\hline Atoll No. & Atoll Name & Alternative Name & Latitude & Longitude \\
\hline 419 & Pinaki $^{\dagger}$ & - & $19.3949^{\circ} \mathrm{S}$ & $138.6751^{\circ} \mathrm{W}$ \\
\hline 420 & Ahunui $^{\dagger}$ & - & $19.6342^{\circ} \mathrm{S}$ & $140.4093^{\circ} \mathrm{W}$ \\
\hline 421 & Hereheretui $^{\dagger}$ & - & $19.8698^{\circ} \mathrm{S}$ & $144.9590^{\circ} \mathrm{W}$ \\
\hline 422 & Anuanurunga $^{\dagger}$ & Anua-nuruga & $20.6135^{\circ} \mathrm{S}$ & $143.2870^{\circ} \mathrm{W}$ \\
\hline 423 & Nukutepipi $^{\dagger}$ & - & $20.7045^{\circ} \mathrm{S}$ & $143.0520^{\circ} \mathrm{W}$ \\
\hline 424 & Anuanuraro $^{\dagger}$ & - & $20.4360^{\circ} \mathrm{S}$ & $143.5355^{\circ} \mathrm{W}$ \\
\hline 425 & Vanavana $^{\dagger}$ & - & $20.7809^{\circ} \mathrm{S}$ & $139.1407^{\circ} \mathrm{W}$ \\
\hline 426 & Tureia $^{\dagger}$ & - & $20.8293^{\circ} \mathrm{S}$ & $138.5390^{\circ} \mathrm{W}$ \\
\hline 427 & Tenararo $^{\dagger}$ & - & $21.3043^{\circ} \mathrm{S}$ & $136.7447^{\circ} \mathrm{W}$ \\
\hline 428 & Vahanga $^{\dagger}$ & Vahaga & $21.3321^{\circ} \mathrm{S}$ & $136.6510^{\circ} \mathrm{W}$ \\
\hline 429 & Tenaruga $^{\dagger}$ & Tenarunga & $21.3451^{\circ} \mathrm{S}$ & $136.5420^{\circ} \mathrm{W}$ \\
\hline 430 & Matureivavao $^{\dagger}$ & - & $21.4721^{\circ} \mathrm{S}$ & $136.3935^{\circ} \mathrm{W}$ \\
\hline 431 & Marutea Sud ${ }^{\dagger}$ & - & $21.5207^{\circ} \mathrm{S}$ & $135.5566^{\circ} \mathrm{W}$ \\
\hline 432 & Temitangi $^{\dagger}$ & Tematagi & $21.6803^{\circ} \mathrm{S}$ & $140.6266^{\circ} \mathrm{W}$ \\
\hline 433 & Muruoa & Mururoa & $21.8347^{\circ} \mathrm{S}$ & $138.8842^{\circ} \mathrm{W}$ \\
\hline 434 & Maria Est ${ }^{\dagger}$ & - & $22.0160^{\circ} \mathrm{S}$ & $136.1892^{\circ} \mathrm{W}$ \\
\hline 435 & Fangataufa $^{\dagger}$ & Fangatau & $22.2356^{\circ} \mathrm{S}$ & $138.7401^{\circ} \mathrm{W}$ \\
\hline \multirow[t]{2}{*}{436} & Morane $^{\dagger}$ & - & $23.1569^{\circ} \mathrm{S}$ & $137.1330^{\circ} \mathrm{W}$ \\
\hline & & Gambier Group & & \\
\hline 437 & Temoe $^{\dagger}$ & - & $23.3466^{\circ} \mathrm{S}$ & $134.4779^{\circ} \mathrm{W}$ \\
\hline
\end{tabular}

Temoe (437) has been moved to the Gambier group of French Polynesia (Table A.21), but no other changes are made from Bryan (1953) to the listing of atolls for the eastern Pacific (Table A.22).

Clipperton atoll is elevated with a closed, meromictic lagoon. It is referred to as an almost-atoll due to a small volcanic protrusion from the rim (Glynn et al., 1996). Henderson Island, an uplifted atoll with no lagoon, is not included. Îlot de Sable in the Marquesas group, listed by Bryan (1953), appears to be a table reef: NGA Sailing Directions (2014b) report breakers over this small atoll reef, which is subsurface save one small sand cay.

Table A.22. Atolls of the Eastern Pacific.

\begin{tabular}{rlll} 
Atoll No. & Atoll Name & Latitude & Longitude \\
\hline 438 & Oeno & $23.9254^{\circ} \mathrm{S}$ & $130.7308^{\circ} \mathrm{W}$ \\
439 & Dulcie & $24.6811^{\circ} \mathrm{S}$ & $124.7854^{\circ} \mathrm{W}$ \\
\hline
\end{tabular}




\section{Appendix B: Salinity and Oxygen Characteristics of Closed Atoll Systems}

Table B.1. Atolls exhibiting brackish, hypersaline, freshwater, or dysoxic lagoons. All atolls listed are closed systems except for those with open lagoons marked by an asterisk (*). Atoll numbers correspond to atoll numbers assigned in Tables A.1-A.22. A question mark (?) indicates contradictory or unknown salinity.

\begin{tabular}{|c|c|c|c|c|c|}
\hline $\begin{array}{c}\text { Atoll } \\
\text { No. }\end{array}$ & Name & Atoll Group & $\begin{array}{l}\text { Lagoon } \\
\text { Dimensions }\end{array}$ & Salinity and Oxygen Characteristics & Reference(s) \\
\hline 4 & Turneffe* & Belize & - & Hypersaline, 40\%o & Hauser et al., 2007 \\
\hline 5 & Lighthouse* & Belize & - & Hypersaline, 40\%о & Hauser et al., 2007 \\
\hline 6 & Glover's* & Belize & - & Hypersaline, $40 \%$ & Hauser et al., 2007 \\
\hline 253 & Pulusuk & Caroline Islands & $\begin{array}{l}15 \text { ha; } \\
1-4 \text { m deep }\end{array}$ & Brackish & Wester et al., 1992 \\
\hline 285 & Lib & Marshall Islands & $\begin{array}{l}7 \text { ha; } \\
\text { 2-3 m deep }\end{array}$ & $\begin{array}{l}\text { Brackish (polyhaline); } \\
\sim 27 \% \text { with tidal connection }\end{array}$ & Myhrvold et al., 2014 \\
\hline 305 & Marakei & Kiribati & $18 \mathrm{~km}^{2}$ & $\sim 10 \%$ & Tebano, 2008 \\
\hline 313 & Nikunau & $\begin{array}{l}\text { Kiribati } \\
\text { (Ellice Islands) }\end{array}$ & $4 \mathrm{~km}^{2}$ & 10\%о & Tebano, 2008 \\
\hline 317 & Niutao & Tuvalu & 7 ha & Brackish, polyhaline? & $\begin{array}{l}\text { Wester et al., 1992; } \\
\text { Krüger, } 2008\end{array}$ \\
\hline 318 & Nanumanga & Tuvalu & 124 ha & Brackish, polyhaline? & $\begin{array}{l}\text { Wester et al., 1992; } \\
\text { Krüger, } 2008\end{array}$ \\
\hline 327 & Laysan & Hawaii & 65-74 ha & $120-150 \%$ & $\begin{array}{l}\text { Caspers, 1981; } \\
\text { Athens et al., } 2007\end{array}$ \\
\hline 331 & Palmyra & Line Islands & $4 \mathrm{~km}^{2}$ & $\begin{array}{l}\text { Four partially isolated lagoons up to } 50 \\
\text { m deep; three are dysoxic at > } 30 \text { m; } \\
\text { bottom waters anoxic with high levels } \\
\text { of sulfide }\end{array}$ & $\begin{array}{l}\text { Gardner et al., } 2011 \\
\text { Gardner et al., } 2014\end{array}$ \\
\hline 332 & Teraina & Line Islands & $\begin{array}{l}73 \mathrm{~km}^{2} \text {; } \\
10 \mathrm{~m} \text { deep }\end{array}$ & Freshwater & Wester et al., 1992 \\
\hline 334 & Kiritimati & Line Islands & $\begin{array}{l}290 \mathrm{~km}^{2}(\sim 75 \\
\left.\mathrm{km}^{2} \text { open}\right)\end{array}$ & $\begin{array}{l}\text { Euhaline in open section; fresh to } \\
>150 \% \text { in closed areas }\end{array}$ & Saenger et al., 2006 \\
\hline 335 & Malden & Line Islands & $14 \mathrm{~km}^{2}$ & Brackish with tidal connection & $\begin{array}{l}\text { Keating, 1992; } \\
\text { Wester et al., } 1992\end{array}$ \\
\hline 336 & Starbuck & Line Islands & $10 \mathrm{~km}^{2}$ & Hypersaline evaporation basin & Keating, 1992 \\
\hline 339 & Enderbury & Phoenix Islands & 10-20 ha & Brackish? & $\begin{array}{l}\text { Wiens, 1962; } \\
\text { Pierce et al., 2010; } \\
\text { Obura, } 2011\end{array}$ \\
\hline 340 & Birnie & Phoenix Islands & 3 ha & Brackish? & $\begin{array}{l}\text { Thorson et al., 2008; } \\
\text { Obura, } 2011\end{array}$ \\
\hline 341 & McKean & Phoenix Islands & 21 ha & Brackish? & Obura, 2011 \\
\hline 342 & Rawaki & Phoenix Islands & 15 ha & Brackish? & $\begin{array}{l}\text { Pierce et al., 2006; } \\
\text { Thorson et al., 2008; } \\
\text { Obura, } 2011\end{array}$ \\
\hline 343 & Manra & Phoenix Islands & $3 \mathrm{~km}^{2}$ & Brackish? & $\begin{array}{l}\text { Wiens, 1962; } \\
\text { Obura, } 2011\end{array}$ \\
\hline 349 & $\begin{array}{l}\text { Olosega } \\
\text { (Swains Island) }\end{array}$ & American Samoa & $\begin{array}{l}3.5 \mathrm{~km}^{2} \text {; } \\
12 \mathrm{~m} \text { deep }\end{array}$ & $4-5 \%$ & $\begin{array}{l}\text { Whistler, 1983; } \\
\text { Van Tilberg et al., } 2013\end{array}$ \\
\hline 370 & Takapoto & Tuamotu Islands & $81 \mathrm{~km}^{2}$ & Hypersaline, 43\%o & Rougerie et al., 1997 \\
\hline 378 & Taiaro & Tuamotu Islands & $12 \mathrm{~km}^{2}$ & Hypersaline, 43\% & Rougerie et al., 1997 \\
\hline 386 & Niau & Tuamotu Islands & $32 \mathrm{~km}^{2}$ & $\begin{array}{l}\text { Brackish (polyhaline), } \\
\text { 25-32\%; suspected of developing low } \\
\text { oxygen levels }\end{array}$ & $\begin{array}{l}\text { Rougerie et al., 1997; } \\
\text { Charpy et al., 2010; } \\
\text { Tröndlé and Salvat, } 2010\end{array}$ \\
\hline- & Clipperton $^{\mathrm{a}}$ & East Pacific & $\begin{array}{l}7 \mathrm{~km}^{2} \text {; } \\
37 \mathrm{~m} \text { deep }\end{array}$ & $\begin{array}{l}\text { Brackish (5\%) to } 10 \mathrm{~m} \text {; euhaline below } \\
10 \mathrm{~m}\end{array}$ & Charpy et al., 2010 \\
\hline
\end{tabular}

\footnotetext{
${ }^{\mathrm{a}}$ An almost-atoll with a meromictic lagoon
} 


\section{Appendix C: Maps of World Atolls}

The six maps that comprise Appendix $\mathrm{C}$ are based on atoll latitude and longitude positions taken from Google Earth or Landsat on the platform or lagoon center. The coordinates were converted to shapefiles and plotted on an ARCgis basemap. The 439 atolls represented here as dots are color coded to depict four atoll classes, as indicated in the map legends. A more complete interactive map with details for each atoll can be found at http://maps.fiu.edu/gis/goldberg/atolls.

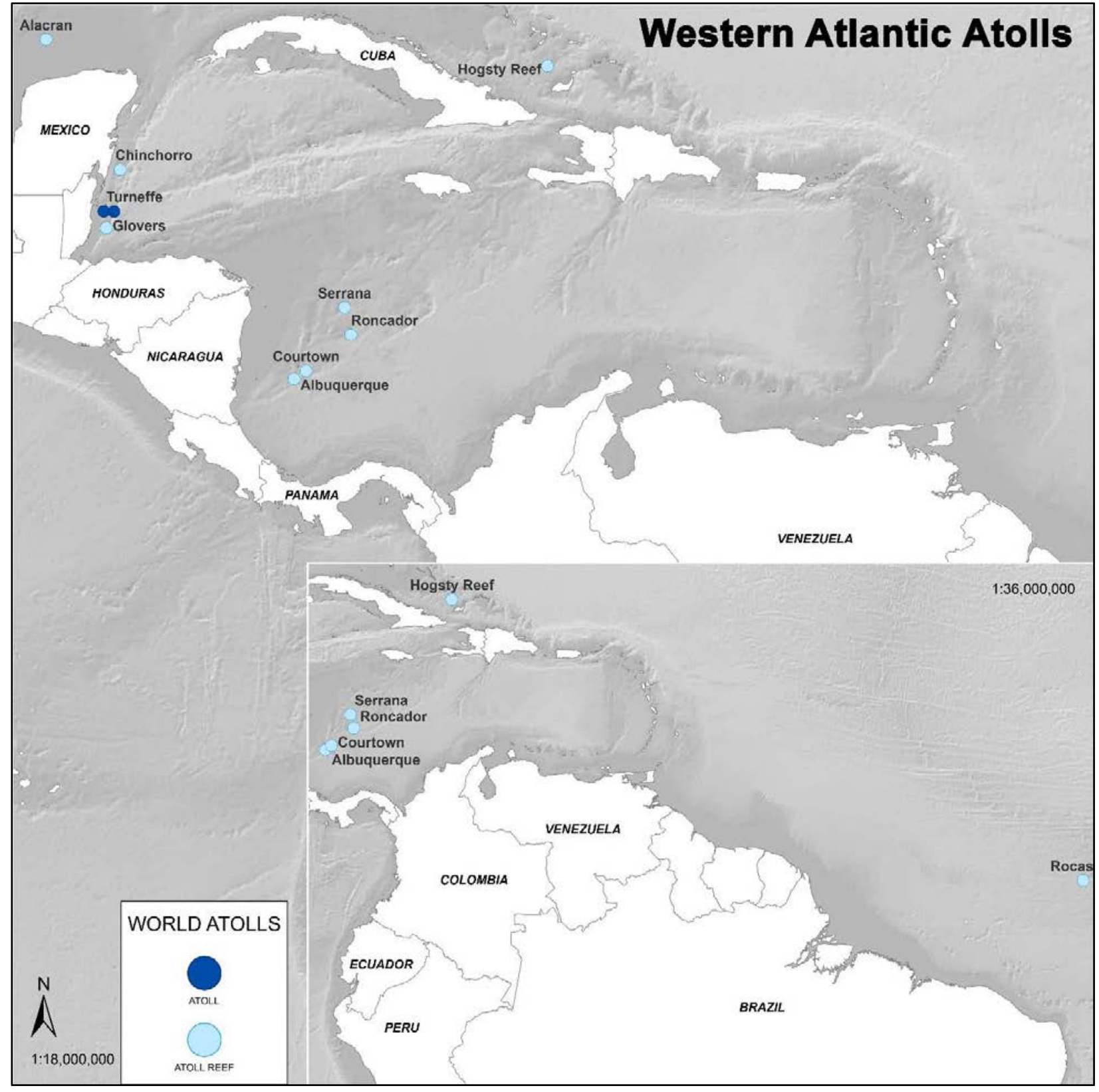

Figure C.1. Atolls of the Western Atlantic. Compare to atoll list in Table A.1. 


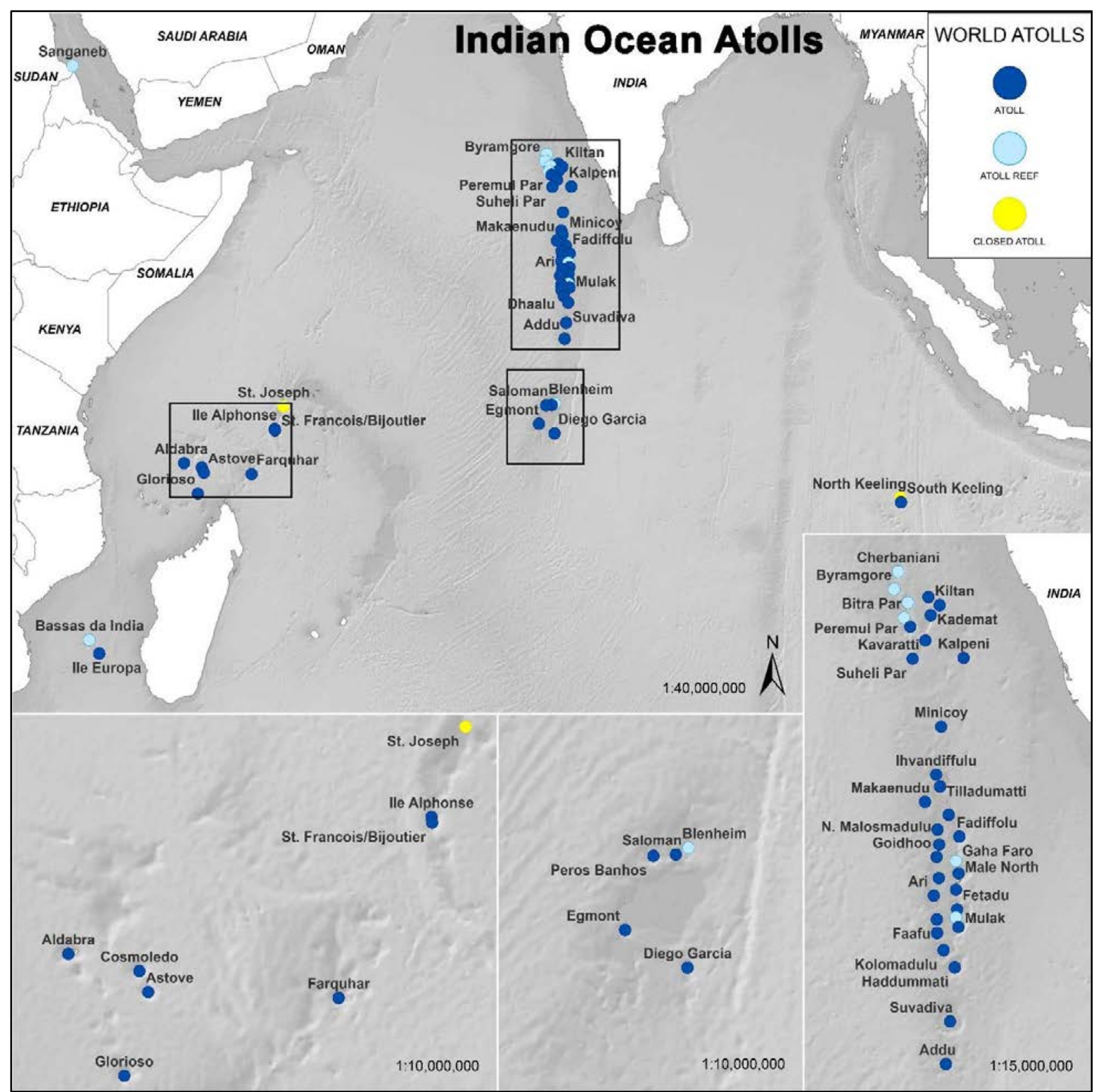

Figure C.2. Atolls of the Indian Ocean, including the Lakshadweep group and the Maldives. Compare to atoll lists in Tables A.2-A.5. 


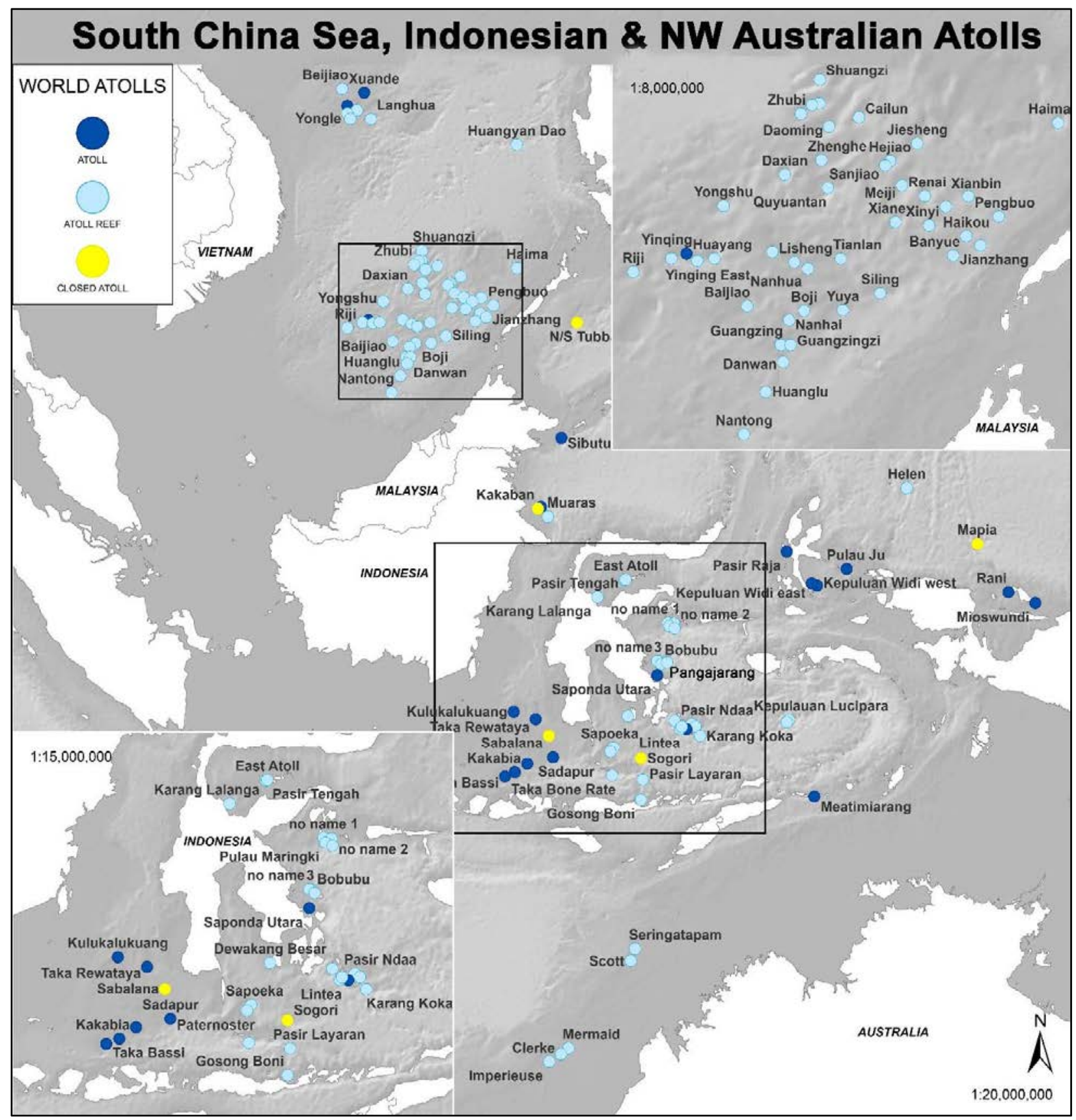

Figure C.3. Atolls in the adjacent seas of the western Pacific, including the South China Sea, Indonesia, and northwestern Australia. Compare to atoll lists in Tables A.3 and A.6-A.8. 


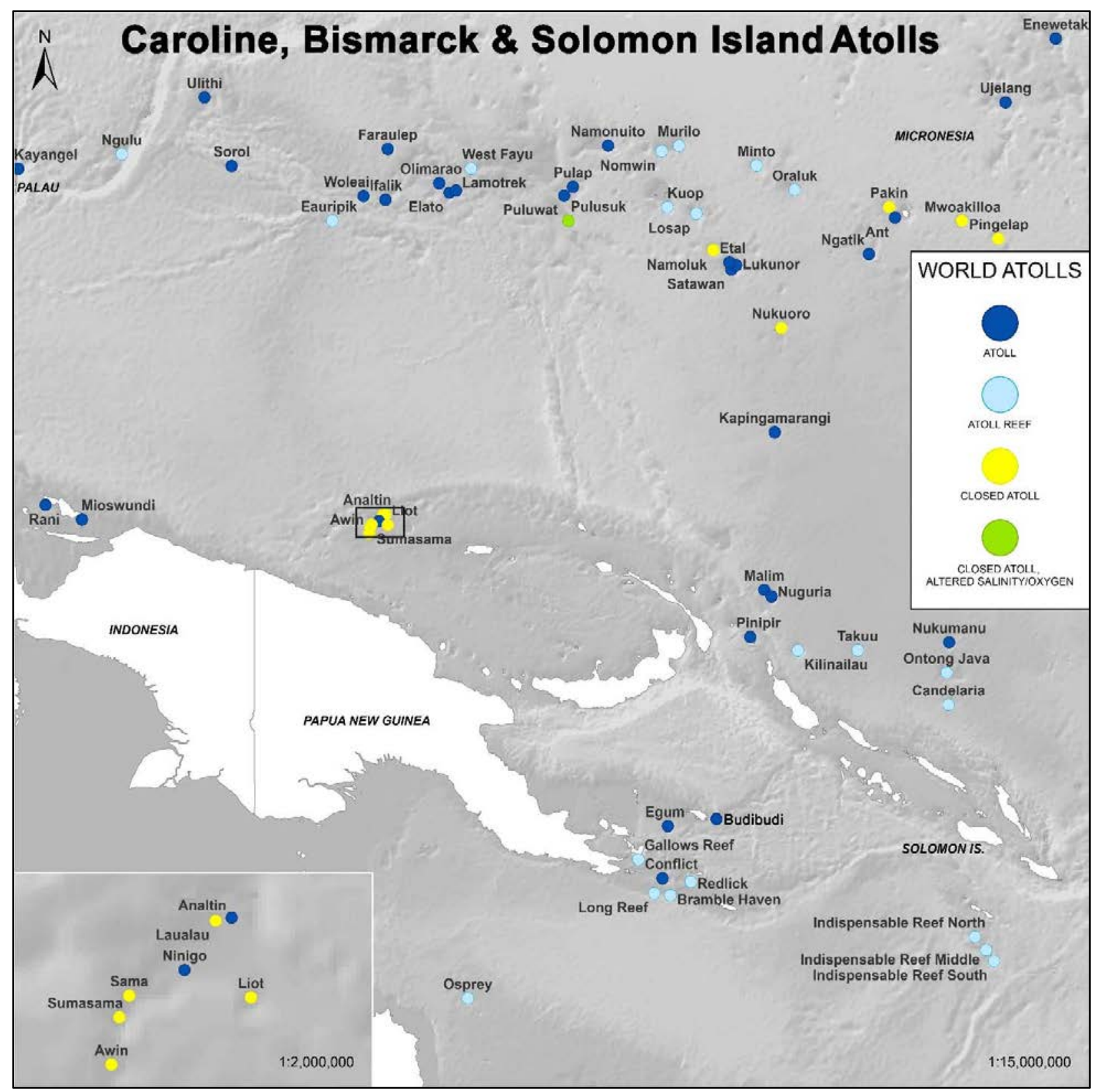

Figure C.4. Atolls from Papua New Guinea to Vanuatu, including the Caroline Islands, the Bismarck archipelago, and the Solomon Islands. Compare to atoll lists in Tables A.9 and A.13. 


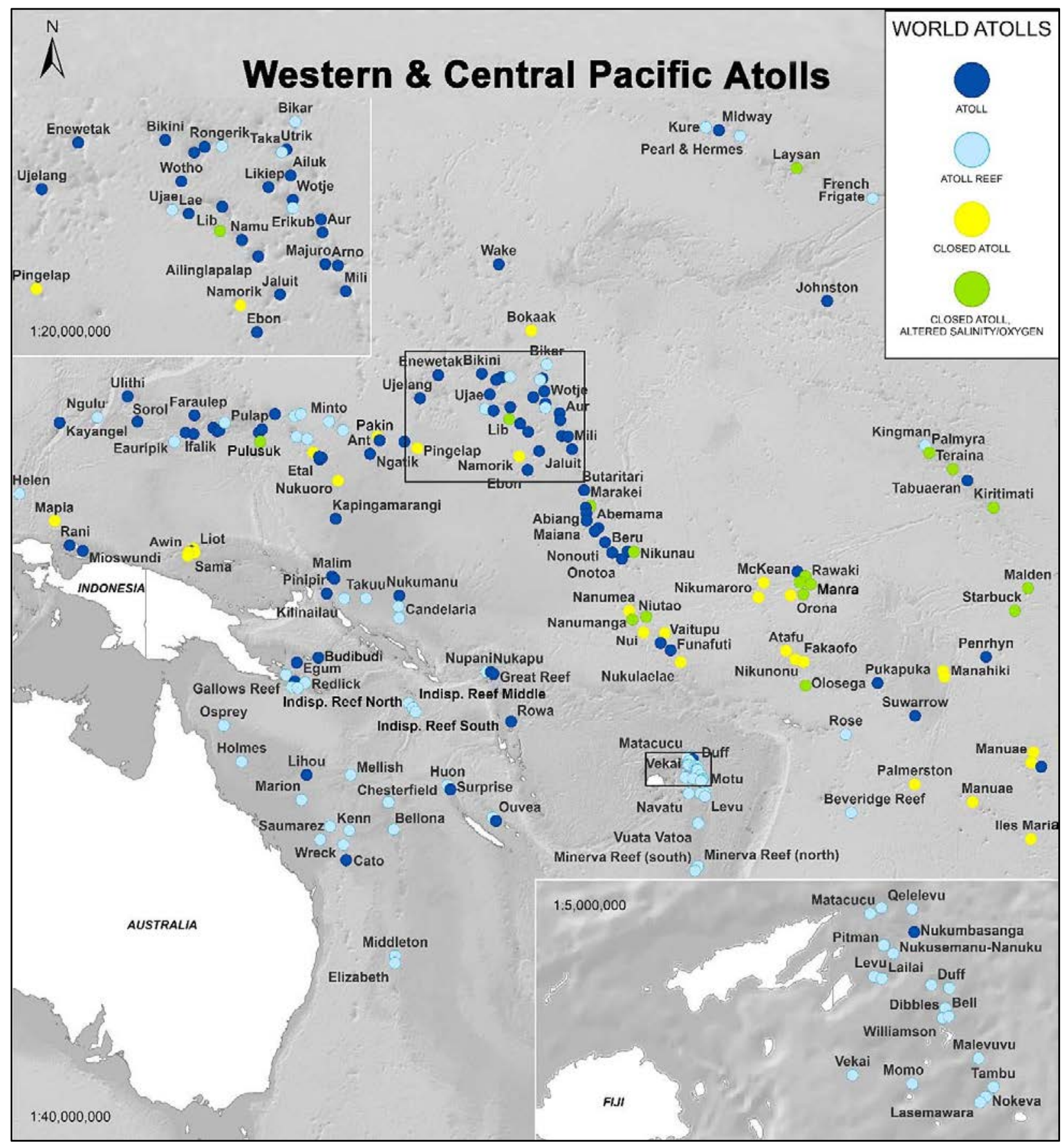

Figure C.5. Atolls of the western and central Pacific, including Fiji, New Caledonia, Australia's Pacific coast, the Marshall Islands, the Gilbert Islands, Tuvalu, Hawaii, and the Cook Islands. Compare to atoll lists in Tables A.10-A.12 and A.14-A.20. 


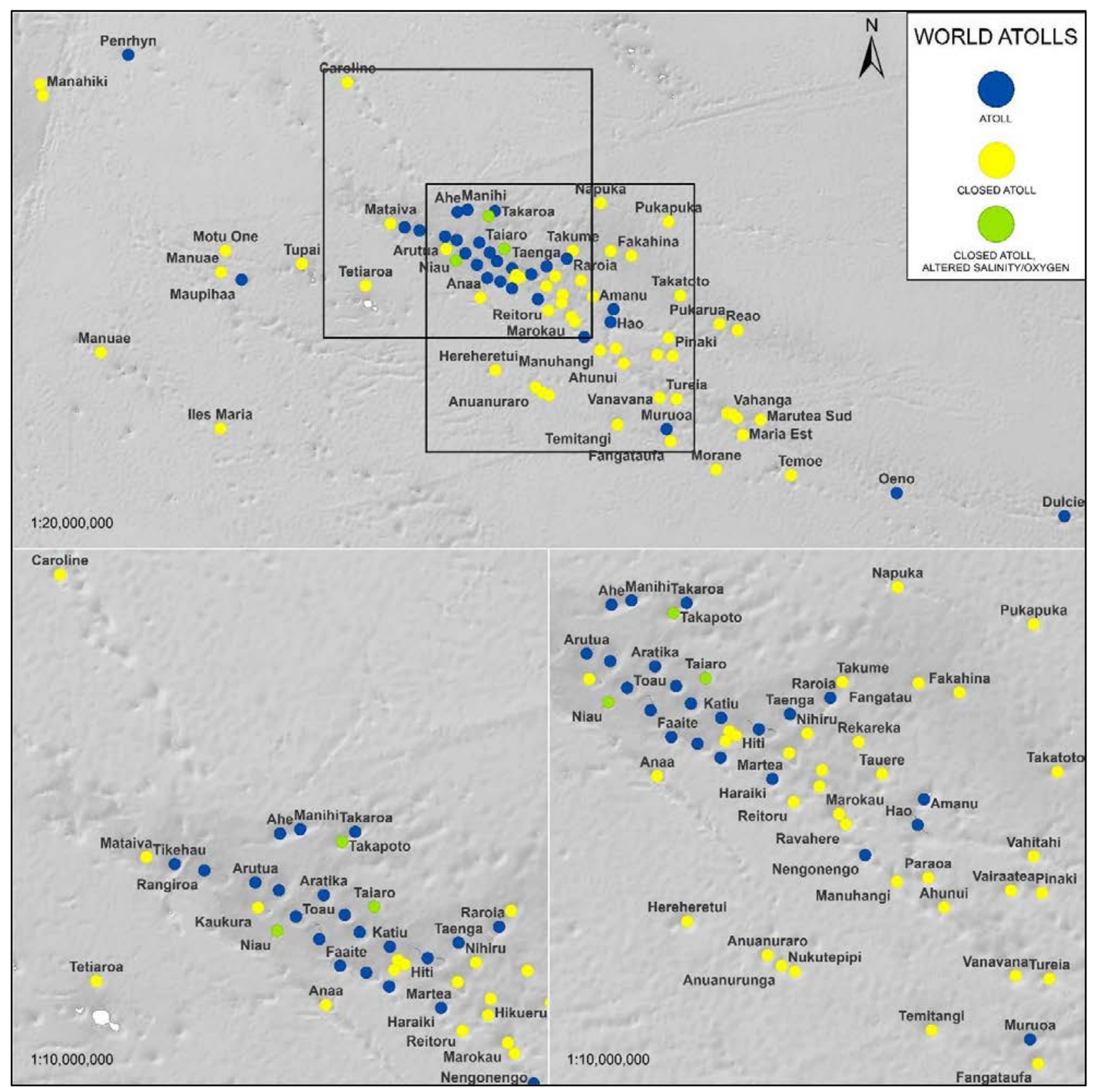

Figure C.6. Atolls of French Polynesia, including Oeno and Dulcie in the eastern Pacific. Compare to atoll lists in Tables A.21 and A.22. 


\section{REFERENCES}

Abby, E., and J. M. Webster. 2011. “Submerged Reefs.” In Encyclopedia of Modern Coral Reefs: Structure, Form and Process, ed. D. Hopley, pp. 1058-1062. Dordrecht, Netherlands: Springer Science+Business Media BV.

Adjeroud, M., S. Andréfouët, C. Payri, and J. Orempuller. 2000. Physical Factors of Differentiation in Macrobenthic Communities between Atoll Lagoons in the Central Tuamotu Archipelago (French Polynesia). Marine Ecology Progress Series, 196:25-38.

Aggasiz, A. 1899. The Islands and Coral Reefs of Fiji. Bulletin of the Museum of Comparative Zoology, 32:1167,120 pls.

Andréfouët, S., J. Pagès, and B. Tartinville. 2001. Water Renewal Time for Classification of Atoll Lagoons in the Tuamotu Archipelago (French Polynesia). Coral Reefs, 20:399-408.

Andréfouët, S., G. Cabioch, B. Flamand, and B. Pelletier. 2009. A Reappraisal of the Diversity of Geomorphological and Genetic Processes of New Caledonian Coral Reefs: A Synthesis from Optical Remote Sensing, Coring and Acoustic Multibeam Observations. Coral Reefs, 28:691-707.

Andréfouët, S., C. Dutheil, C. E. Menkes, M. Bador, and M. Lengaigne. 2015. Mass Mortality Events in Atoll Lagoons: Environmental Control and Increased Future Vulnerability. Global Change Biology, 21:195205.

Athens, J. S., J. V. Ward, and D. W. Blinn. 2007. Vegetation History of Laysan Island, Northwest Hawaiian Islands. Pacific Science, 61:17-37.

Atkinson, M., S. V. Smith, and E. D. Stroup. 1981. Circulation in Enewetak Atoll Lagoon. Limnology and Oceanography, 26:1074-1083.

Bailey, R. T., and J. W. Jenson. 2014. Effects of Marine Overwash for Atoll Aquifers: Environmental and Human Factors. Groundwater, 52:694-704.

Bayne, C. J., B. H. Cogan, A. W. Diamond, J. Frazer, P. Grubb, A. Hutson, M. E. D. Poore, D. R. Stoddart, and J. D. Taylor. 1970. Geography and Ecology of Astove. Atoll Research Bulletin, 136:83-99.

Beaman, R. J., J. M. Webster, and A. J. Wust. 2008. New Evidence for Drowned Shelf Edge Reefs in the Great Barrier Reef, Australia. Marine Geology, 247:17-34.

Braithwaite, C. J. R., J. D. Taylor, and W. J. Kennedy. 1973. The Evolution of an Atoll: The Depositional and Erosional History of Aldabra. Philosophical Transactions of the Royal Society B, 266:307-340.

Bryan, E. H., Jr. 1953. A Check List of Atolls. Atoll Research Bulletin, 19:1-38.

Callaghan, D. P., P. Nielsen, N. Cartwright, M. R. Gourlay, and T. E. Baldock. 2006. Atoll Lagoon Flushing Forced by Waves. Coastal Engineering, 53:691-704.

Caspers, H. 1981. On the Ecology of Hypersaline Lagoons on Laysan Atoll and Kauai Island, Hawaii, with Special Reference to the Laysan Duck, Anas laysanensis Rothschild. Hydrobiology, 82:261-270.

Ceccarelli, D. 2011. Australia's Coral Sea: A Biophysical Profile. Report for the Protect our Coral Sea Coalition. http://www.saveourmarinelife.org.au/wpcontent/uploads/2014/08/AustraliasCoralSeaABiophysicalProfileDrDanielaCeccarelli.pdf

Charpy, L., M. Rodier, A. Couté, C. Perrette-Gallet, and C. Bley-Loëz. 2010. Clipperton, a Possible Future for Atoll Lagoons. Coral Reefs, 29:771-783.

Chevalier, J. P. 1973. “Coral Reefs of New Caledonia.” In Biology and Geology of Coral Reefs: Volume 1, Geology 1, ed. O. A. Jones and R. Endean, pp. 143-167. New York: Academic Press.

Cloud, P. E., Jr. 1952. Facies Relationships of Organic Reefs. American Association of Petroleum Geologists Bulletin, 36:2125-2149.

- 1953. "Nature and Origin of Atolls." In Proceedings of the Eight Pacific Science Congress of the Pacific Science Association, Vol. III A, pp. 1009-1023. Quezon City, Philippines: National Research Council of the Philippines.

Dana, T. F. 1979. Species Numbers Relationships in an Assemblage of Reef-Building Corals: McKean Island, Phoenix Islands. Atoll Research Bulletin, 228:1-40.

Davis, W. M. 1928. The Coral Reef Problem. Special Publication 9, American Geographical Society. New York: AMS Press. 
Deshmukh, B., A. Bahuguna, S. Nyak, V. K. Dhargalkar, and T. G. Jagtap. 2005. Eco-Geomorphological Zonation of the Bangaram Reef, Lakshadweep. Indian Journal of Remote Sensing, 33:99-106.

Dickinson, W. R. 2004. Impacts of Eustasy and Hydro-Eustasy on the Evolution and Landforms of Pacific Atolls. Palaeogeography, Paleoclimatology, Paleoecology, 213:251-269.

- 2013. Control of Paleoshorelines by Trench Forebulge Uplift, Loyalty Islands. Quaternary Research, 80:125-137.

Dubois, J., J. Launay, and J. Recy. 1974. Uplift Movements in New Caledonia-Loyalty Islands Area and Their Plate Tectonics Interpretation. Tectonophysics, 24:133-150.

Dumas, F., L. Le Gendre, Y. Thomas, and S. Andréfouët. 2012. Tidal Flushing and Wind Driven Circulation of Ahe Atoll Lagoon, (Tuamotu Archipelago, French Polynesia) from in situ Observations and Numerical Modeling. Marine Pollution Bulletin, 65:425-440.

Gardner, J. P. A., D. W. Garton, and J. D. Collen. 2011. Near-Surface Mixing and Pronounced Deep-Water Stratification in a Compartmentalised, Human-Disturbed Atoll Lagoon System. Coral Reefs, 30:271-282.

Gardner, J. P. A., D. W. Garton, J. D. Collen, and D. Zwartz. 2014. Distant Storms as Drivers of Environmental Change at Pacific Atolls. PLoS ONE, 9(1):e87971. doi:10.1371/journal.pone.0087971.

Garrigue, C., B. Richer de Forges, P. Laboute, J.-S. Philippe, V. Chazottes, G. Correge, and J. Récy. 2000. Paléo-Surprise: paleóenvironments et bioécologie de l'atoll de Surprise, Nouvelle- Calédonie. Science de la Mer Biologie Marine 25. Noumea, New Caledonia: Institut de la Recherche pour le Développment.

Geister, J. 1983. Holocene West Indian Coral Reefs: Geomorphology, Ecology and Facies. Facies, 9:173-284.

Gherardi, D. F. M., and D. W. J. Bosence. 2005. Late Holocene Reef Growth and Relative Sea-Level Changes in Atol das Rocas, Equatorial South Atlantic. Coral Reefs, 24:264-272.

Gischler, E. 2003. Holocene Lagoon Development in the Isolated Carbonate Platforms off Belize. Sedimentary Geology, 159:113-132.

— . In press. "Guyot and Atoll.” In Encyclopedia of Marine Geosciences, ed. J. Harff, M. Meschede, S. Petersen, and J. Thiede. Dordrecht, Netherlands: Springer Science+Business Media.

Glynn, P. W., J. E. N. Veron, and G. M. Wellington. 1996. Clipperton Island (Eastern Pacific): Oceanography, Geomorphology, Reef-Building Coral Ecology and Biogeography. Coral Reefs, 15:71-99.

Grigg, R. W. 2008. "Darwin Point: A Conceptual and Historical Review." In Proceedings of the $11^{\text {th }}$ International Coral Reef Symposium, Vol. 1, ed. B. Riegl and R. E. Dodge, pp. 54-56. ICRS Conference Proceedings. Davie, FL: Nova Southeastern University National Coral Reef Institute.

Guilcher, A. 1988. Coral Reef Geomorphology. New York: J. Wiley \& Sons.

Guozhong, W. 1998. “Tectonic and Monsoonal Controls on Coral Atolls in the South China Sea.” In Reefs and Carbonate Platforms in the Pacific and Indian Oceans, ed. G. F. Camoin and P. J. Davies, pp. 237248. Special Publications of the International Association of Sedimentologists 25. Oxford: Blackwell Science.

Hamylton, S., S. Andréfouët, and T. Spencer. 2012. Comparing the Information Content of Coral Reef Geomorphological and Biological Habitat Maps, Amirantes Archipelago (Seychelles), Western Indian Ocean. Estuarine and Coastal Shelf Science, 111:151-156.

Hancox, D., and V. Prescott. 1995. A Geographical Description of the Spratly Islands and an Account of Hydrographic Surveys amongst Those Islands. Maritime Briefings 1(6). Durham, UK: International Boundaries Unit, University of Durham.

Hauser, I., W. Oschmann, and E. Gischler. 2007. Modern Bivalve Shell Assemblages on Three Different Atolls offshore Belize (Central America, Caribbean Sea). Facies, 53:451-478.

Head, S. M. 1987. Corals and Coral Reefs of the Red Sea. In Red Sea, ed. A. J. Edwards and S. M. Head, pp. 128-151. Oxford: Pergamon Press.

Isaac, A., and E. Gischler. 2015. The Significance of Sand Aprons in Holocene Atolls and Carbonate Platforms. Carbonates and Evaporites, September 2015. doi:10.1007/s13146-015-0268-z.

Jehl, C., and F. Rougerie. 1995. Phosphatogenèse en atolls polynésiens: la filiation mattes cyanobactériennes phosphorites. Oceanologica Acta, 18:79-93. 
Job, S., and D. Ceccarelli. 2012. Tuvalu Marine Life: Scientific Report. An Alofa Tuvalu Project, with the Tuvalu Fisheries Department and Funafuti, Nanumea, Nukulaelae Kaupules. Tuvalu: Tuvalu Fisheries Department. http://www.alofatuvalu.tv/US/05 a tuvalu/05_page tml/livret4light.pdf?bcsi scan 2687365 ababd2c82=0\&bcsi_scan_filename=livret4light.pdf

Keating, B. 1992. "Insular Geology of the Line Islands.” In Geology and Offshore Mineral Resources of the Central Pacific Basin, Earth Science Series 14, ed. B. H. Keating and B. R. Bolton, pp.77-99. New York: Springer-Verlag.

Kench, P. S. 1998. Physical Processes in an Indian Ocean Atoll. Coral Reefs, 17:155-168.

Kench, P. S., and P. J. Cowell. 2003. "Variations in Sediment Production and Implications for Atoll Island Stability under Rising Sea Level.” In Proceedings of the 9th International Coral Reef Symposium, Vol. 2, ed. M. K. Moosa et al., pp. 1181-1186. ICRS Conference Proceedings. Bali, Indonesia: Ministry of Environment.

Kench, P. S., R. W. Brander, K. E. Parnell, and R. McLean. 2006. Wave Energy Gradients across a Maldivian Atoll: Implications for Island Geomorphology. Geomorphology, 81:1-17.

Kench, P. S., R. W. Brander, K. E. Parnell, and J. M. O’Callaghan. 2009. Seasonal Variations in Wave Characteristics around a Coral Reef Island, South Maalhosmadulu Atoll, Maldives. Marine Geology, 262:116-129.

Kinsey, D. W., and D. Hopley. 1991. The Significance of Coral Reefs as Global Carbon Sinks—Response to Greenhouse. Palaeogeography, Paleoclimatology, Paleoecology, 89:363-377.

Kleypas, J. A., J. W. McManus, and L. A. B. Meñez. 1999. Environmental Limits to Coral Reef Development: Where Do We Draw the Line? American Zoologist, 39:146-159.

Kraines, S., M. Isobe, and H. Komiyama. 2001. Seasonal Variations in the Exchange of Water-Borne Particles at Majuro Atoll, the Republic of the Marshall Islands. Coral Reefs, 20:330-340.

Krüger, J. 2008. High-Resolution Bathymetric Survey of Tuvalu. EU EDF 8 - SOPAC Project Report 50. Suva, Fiji: Pacific Islands Applied Geoscience Commission.

Ladd, H. S. 1977. "Types of Coral Reefs and Their Distribution.” In The Biology and Geology of Coral Reefs: Volume IV, Geology 2, ed. O. A. Jones and R. Endean, pp. 1-19. New York: Academic Press.

Larson, C. 2015. China’s Island Building Is Destroying Reefs. Science, 349:1434.

Lobel, P. S., and L. K. Lobel. 2008. "Aspects of the Biology and Geomorphology of Johnson and Wake Atolls, Pacific Ocean.” In Coral Reefs of the USA, ed. B. M. Riegl and R. E. Dodge, pp. 655-689. Dordrecht, Netherlands: Springer Science+Business Media BV.

MacNeil, F. S. 1972. "Physical and Biological Aspects of Atolls in the Northern Marshalls." In Proceedings of the $1^{\text {st }}$ International Coral Reef Symposium, ed. C. Mukundan and C. S. Gopindha Pillai, pp. 507-567. ICRS Conference Proceedings. Cochin, India: Marine Biological Association of India.

Maragos, J., J. Miller, J. Gove, E. DeMartini, A. M. Friedlander, S. Godwin, C. Musberger, M. Timmers, R. Tsuda, P. Vroom, E. Flint, E. Lundblad, J. Weis, P. Ayotte, E. Sala, S. Sandin, S. McTee, T. Wass, D. Siciliano, R. Brainard, D. Obura, S. Ferguson, and B. Mundy. 2008a. "US Coral Reefs in the Line and Phoenix Islands, Central Pacific Ocean: History, Geology, Oceanography, and Biology.” In Coral Reefs of the USA, ed. B. M. Riegl and R. E. Dodge, pp. 595-641. Dordrecht, Netherlands: Springer Science+Business Media BV.

Maragos, J., A. M. Friedlander, S. Godwin, C. Musburger, R. Tsuda, E. Flint, O. Pantos, P. Ayotte, E. Sala, S. Sandin, S. McTee, D. Siciliano, and D. Obura. 2008b. "US Coral Reefs in the Line and Phoenix Islands, Central Pacific Ocean: Status, Threats and Significance.” In Coral Reefs of the USA, ed. B. M. Riegl and R. E. Dodge, pp. 643-654. Dordrecht, Netherlands: Springer Science+Business Media BV.

Maragos, J., and G. J. Williams. 2011. "Pacific Coral Reefs: An Introduction.” In Encyclopedia of Modern Coral Reefs, Structure, Form and Process, ed. D. Hopley, pp. 753-776. Dordrecht, Netherlands: Springer Science+Business Media BV.

McLean, R. F. 2011. “Atoll Islands (Motu).” In Encyclopedia of Modern Coral Reefs, Structure, Form and Process, ed. D. Hopley, pp. 47-51. Dordrecht, Netherlands: Springer Science+Business Media BV.

McLean, R. F., and P. L. Hosking. 1991. Geomorphology of Reef Islands and Atoll Motu in Tuvalu. South Pacific Journal of Natural Science, 11:167-189. 
McNutt, M., and H. W. Menard. 1978. Lithospheric Flexure and Uplifted Atolls. Journal of Geophysical Research, 83:1206-1212.

Menard, H. W. 1986. Islands. New York: Scientific American Library.

Milliman, J. D. 1967. The Geomorphology and History of Hogsty Reef, a Bahamian Atoll. Bulletin of Marine Science, 17:519-543.

- 1969. Four Southwestern Caribbean Atolls: Courtown Cays, Albuquerque Cays, Roncador Bank and Serrana Bank. Atoll Research Bulletin, 129:1-41.

—. 1973. "Caribbean Coral Reefs.” In Biology and Geology of Coral Reefs: Volume 1, Geology 1, ed. O. A. Jones and R. Endean, pp. 1-50. New York: Academic Press.

Montaggioni, L. F., and G. F. Camoin. 1997. "Geology of Makatea Island, Tuamotu Archipelago, French Polynesia.” In Geology and Hydrogeology of Carbonate Islands, ed. H. L. Vacher and T. Quinn, pp. 453473. Developments in Sedimentology 54. Amsterdam: Elsevier.

Montaggioni, L. F., J. Borgomano, F. Fournier, and D. Grangeon. 2015. Quaternary Atoll Development: New Insights from the Two-Dimensional Stratigraphic Forward Modeling of Mururoa Island (Central Pacific Ocean). Sedimentology, 62:466-500.

Morton, B., and G. Blackmore. 2001. South China Sea. Marine Pollution Bulletin, 42:1236-1263.

Myhrvold, C. L., J. Fran, D. Nelson, N. Ladd, A. Atwood, and J. P. Sachs. 2014. Holocene Closure of Lib Pond, Marshall Islands. PLoS ONE, 9(3):e90939.

Neall, V. E., and S. A. Trewick. 2008. The Age and Origin of the Pacific Islands: A Geological Overview. Proceedings of the Royal Society B, 363:3293-3308.

Newell, N. D., and J. K. Rigby. 1957. "Geological Studies on the Great Bahama Bank.” In Regional Aspects of Carbonate Deposition, ed. R. J. LeBlanc and J. Breeding, pp. 15-72. American Association of Petroleum Geologists Special Publication 5. Tulsa: Society of Economic Paleontologists and Mineralogists.

National Geospatial-Intelligence Agency (NGA). 2005. Sailing Directions: Indonesia Borneo, Jawa, Sulawesi and Nusa Tengarra. Publication 163. Springfield, VA: National Geospatial-Intelligence Agency.

- 2014a. Sailing Directions: South China Sea. Publication 161. Springfield, VA: National GeospatialIntelligence Agency.

—. 2014b. Sailing Directions: Pacific Islands. Publication 126. Springfield, VA: National GeospatialIntelligence Agency.

Nunn, P. D. 1987. Late Cenozoic Tectonic History of Lau Ridge, Southwest Pacific, and Associated Shoreline Displacements: Review and Synthesis. New Zealand Journal of Geology and Geophysics, 30:241-260.

-1994. Oceanic Islands. Oxford: Blackwell.

Nunn, P. D., C. Ollier, G. Hope, P. Rodda, A. Omura, and W. R. Peltier. 2002. Late Quaternary Sea-Level and Tectonic Changes in Northeast Fiji. Marine Geology, 187:299-311.

Obura, D. 2011. Coral Reef Structure and Zonation of the Phoenix Islands. Atoll Research Bulletin, 589:6382.

Orme, G. R. 1977. “The Coral Sea Plateau-A Major Reef Province.” In The Biology and Geology of Coral Reefs: Volume IV, Geology 2, ed. O. A. Jones and R. Endean, pp. 267-306. New York: Academic Press.

Pagès, J., and S. Andréfouët. 2001. A Reconnaissance Approach for Hydrology of Atoll Lagoons. Coral Reefs, 20:409-414.

Pelletier, B. 2007. "Geology of the New Caledonia Region and Its Implications for the Study of the New Caledonian Biodiversity.” In Compendium of Marine Species of New Caledonia, ed. C. E. Payri and B. Richer de Forger, pp. 19-32. Noumea, New Caledonia: Institut de Recherche pour le Développement.

Perry, C. T., T. Spencer, and P. S. Kench. 2008. Carbonate Budgets and Reef Production States: A Geomorphic Perspective on the Ecological Phase-Shift Concept. Coral Reefs, 27:853-866.

Perry, C. T., P. S. Kench, S. G. Smithers, B. Riegl, H. Yamano, and M. J. O’Leary. 2011. Implications of Reef Ecosystem Change for the Stability and Maintenance of Coral Reef Islands. Global Change Biology, 17:3679-3696. 
Pierce, R. J., T. Etei, V. Kerr, A. Saul, M. Teatata, M. Thorson, and G. Wragg. 2006. Phoenix Islands Conservation Survey and Assessment of Restoration Feasibility: Kiribati. Report prepared for Conservation International Samoa and Pacific Islands Initiative, Auckland University. Whangarei, New Zealand: Eco Oceania Ltd.

Pierce, R. J., N. Anterea, G. Coulston, C. Gardiner, L. Shilton, K. Taabu, and G. Wragg. 2011. Atoll Restoration in the Phoenix Islands, Kiribati: Survey Results November-December 2009. Biodiversity Conservation Lessons Learned Technical Series 7. With Conservation International Pacific Islands Program. Apia, Samoa: Conservation International. http://www.cepf.net/Documents/7_Phoenix_Is_Atoll.pdf

Pirazzoli, P. A. 1994. “Tectonic Shorelines.” In Coastal Evolution in the Quaternary, ed. R. W. G. Carter and C. D. Woodroffe, pp. 451-476. Cambridge, UK: Cambridge University Press.

Pirazzoli, P. A., L. F. Montaggioni, B. Salvat, and G. Faure. 1988. Late Holocene Sea Level Indicators from Twelve Atolls in the Central and Eastern Tuamotus (Pacific Ocean). Coral Reefs, 7:57-68.

Prakash, T. N. 2015. “Lakshadweep Islands.” In Geomorphology and Physical Oceanography of the Lakshadweep Coral Islands in the Indian Ocean, ed. T. N. Prakash, L. S. Nair, and T. S. S. Hameed, pp. 1-16. SpringerBriefs in Earth Sciences. Cham, Switzerland: Springer.

Pugh, D. T. 1979. Sea Levels at Aldabra Atoll, Mombasa and Mahé, Western Equatorial Indian Ocean, Related to Tides, Meteorology and Ocean Circulation. Deep Sea Research, 26:237-258.

Purdy, E. G., and E. L. Winterer. 2001. Origin of Atoll Lagoons. Geological Society of America Bulletin, 113:837-854.

- 2006. Contradicting Barrier Reef Relationships for Darwin's Evolution of Reef Types. International Journal of Earth Sciences, 95:143-167.

Quod, J. P., A. Barrére, P. Chabanet, P. Durville, J. B. Nicet, and R. Garnier. 2007. La situation des récifs Coralliens des îles eparses françaises de l'Océan Indien. Revue d'Ecologie (Terre Vie), 62:3-16.

Rankey, E. C., and J. R. Garza-Pérez. 2012. Seascape Metrics of Shelf-Margin Reefs and Sand Aprons of Holocene Carbonate Platforms. Journal of Sedimentary Research, 82:53-71.

Rankey, E., S. L. Reeder, and J. R. Garza-Pérez. 2011. Controls on Links on Geomorphical and Surface Sedimentological Variability: Aitutaki and Maupiti Atolls, South Pacific Ocean. Journal of Sedimentary Research, 81:885-900.

Reinicke, G. B., D. K. Kroll, and H. Schumacher. 2003. Patterns of Changes of Reef Communities at the Sanganeb-Atoll (Sudan, Central Red Sea): 1990-1991. Facies, 49:271-298.

Rougerie, F., R. Fichez, and P. Déjardin. 1997. "Geomorphology and Hydrogeology of Selected Islands of French Polynesia: Tikehau (Atoll) and Tahiti (Barrier Reef).” In Geology and Hydrogeology of Carbonate Islands, ed. H. L. Vacher and T. Quinn, pp. 475-502. Developments in Sedimentology 54. Amsterdam: Elsevier.

Saenger, C., M. Miller, R. H. Smittenberg, and J. P. Sachs. 2006. A Physico-Chemical Survey of Inland Lakes and Saline Ponds: Christmas Island (Kiritimati) and Washington (Teraina) Islands, Republic of Kiribati. Saline Systems, 2:8. doi:10.1186/1746-1448-2-8. http://www.salinesystems.org/content/2/1/8 (accessed 14 June 2016).

Salvat, B. 1985. "An Integrated (Geomorphological and Economical) Classification of French Polynesian Atolls.” In Proceedings of the 5th International Coral Reef Congress, Vol. 2, ed. C. Gabrie, J. L. Toffart, and B. Salvat, p. 337. Moorea, French Polynesia: Antenne Museum-EPHE.

- 2009. Dominant Benthic Mollusks in Closed Atolls, French Polynesia. Galaxea, 11:197-206.

Schlanger, S. O., and G. W. Gillett. 1976. A Geological Perspective of the Upland Biota of Laysan Atoll. Biological Journal of the Linnaean Society, 8:205-216.

Scott, G. A. J., and G. M. Rotondo. 1983. A Model to Explain the Differences between Pacific Plate Island Atoll Types. Coral Reefs, 1:139-150.

Sheppard, C. R. C. 2000. “The Chagos Archipelago.” In Coral Reefs of the Indian Ocean, Their Ecology and Conservation, ed. T. R. McClanahan, C. R. C. Sheppard, and D. O. Obura, pp. 445-470. Oxford: Oxford University Press. 
Sheppard, C. R. C., B. W. Bowen, A. C. Chen, M. T. Craig, J. Eble, N. Fitzsimmons, C.-H. Gan, M. R. Gaither, M. Gollock, S. Keshavmurthy, H. Koldewey, J. A. Mortimer, D. Obura, M. Pfeiffer, A. D. Rogers, A. L. S. Sheppard, C. Vogler, G. Wörheide, M.-C. Yang, and C. Yesson. 2013. "British Indian Ocean Territory (the Chagos Archipelago): Setting, Connections and the Marine Protected Area.” In Coral Reefs of the United Kingdom Overseas Territories, Coral Reefs of the World 4, ed. C. R. C. Sheppard, pp. 223-240. Dordrecht, Netherlands: Springer Science+Business Media.

Sinha, B. N. 1994. Geo-Economic Survey of Lakshadweep. New Delhi: Concept Publishing Co.

Spalding, M. D., C. Ravilious, and E. P. Green. 2001. World Atlas of Coral Reefs. Berkeley: UNEP-WCMC and University of California Press.

Spencer, T., A. B. Hagan, S. M. Hamylton, and P. Renaud. 2009. The Atlas of the Amirantes. Cambridge, UK: Cambridge Coastal Research Unit, University of Cambridge.

Spriggs, M. 1991. "Nissan, the Island in the Middle.” In Report of the Lapita Homeland Project, ed. J. Allen and C. Gosden, pp. 222-243. Occasional Papers in Prehistory 20. Canberra: Australian National University.

Stoddart, D. R. 1962. Three Caribbean Atolls: Turneffe Islands, Lighthouse Reef, and Glover’s Reef, British Honduras. Atoll Research Bulletin, 87:1-151.

- 1965. The Shape of Atolls. Marine Geology, 3:369-383. . 1970. Coral Islands of the Western Indian Ocean. Atoll Research Bulletin, 136:1-224.

— 1973. “Coral Reefs of the Indian Ocean.” In Biology and Geology of Coral Reefs: Volume 1, Geology 1, ed. O. A. Jones and R. Endean, pp. 51-92. New York: Academic Press.

- 1975. Almost-Atoll of Aitutaki: Geomorphology of Reefs and Islands. Atoll Research Bulletin, 190:31-57.

— 1984. "Coral Reefs of the Seychelles and Adjacent Regions." In Biogeography and Ecology of the Seychelles Island, ed. D. R. Stoddart, pp. 63-81. The Hague: Dr. W. Junk Publishers.

Stoddart, D. R., J. D. Taylor, F. R. Fosberg, and G. E. Farrow. 1971. Geomorphology of Aldabra Atoll. Philosophical Transactions of the Royal Society London B, 260:31-66.

Stoddart, D. R., and J. A. Steers. 1977. “The Nature and Origin of Coral Reef Islands.” In The Biology and Geology of Coral Reefs: Volume IV, Geology 2, ed. O. A. Jones and R. Endean, pp. 59-105. New York: Academic Press.

Stoddart, D. R., and F. R. Fosberg. 1994. The Hoa of Hull Atoll and the Problem of Hoa. Atoll Research Bulletin, 394:1-26.

Suzuki, A., and H. Kawahata. 1999. Partial Pressure of Carbon Dioxide in Coral Reef Lagoon Waters: Comparative Study of Atolls and Barrier Reefs in the Indo-Pacific Oceans. Journal of Oceanography, 55:731-745.

Tayama, R. 1935. Table Reefs, a Particular Type of Coral Reefs. Proceedings of the Imperial Academy, 11:268-270.

Tebano, T. 2008. A Preliminary Identification of Cyanophyta/Cyanobacteria in the Brackish Milkfish Ponds of Marakei, Nikunau and Kiritimati Atolls, Republic of Kiribati. South Pacific Journal of Natural and Applied Sciences, 26:62-67.

Terry, P., and P. D. Nunn. 2003. Interpreting Features of Carbonate Geomorphology on Niue Island, a Raised Atoll. Zeitschrift für Geomorphologie NF (suppl.), 131:43-57.

Thornborough, K. J., and P. J. Davies. 2011. "Reef Flats.” In Encyclopedia of Modern Coral Reefs, Structure, Form and Process, ed. D. Hopley, pp. 869-876. Dordrecht, Netherlands: Springer Science+Business Media BV.

Thorson, M., R. Pierce, and K. Broome. 2008. Operational Plan for the Eradication of Three Exotic Mammal Species from Three Islands in the Phoenix Group, Kiribati. Auckland: New Zealand Department of Conservation.

Tomascik, T., and A. J. Mah. 1994. The Ecology of "Halimeda Lagoon”: An Anchialine Lagoon of a Raised Atoll, Kakaban Island, East Kalamantan, Indonesia. Tropical Biodiversity, 2:385-399.

Tomascik, T., A. J. Mah, A. Nontji, and M. K. Moosa. 1997. The Ecology of the Indonesian Seas Part Two. Hong Kong: Periplus. 
Tröndlé, J., and B. Salvat. 2010. La thanatocénose du lagon de l’atoll Niau (Polynésie française) avec la description d'une nouvelle espèce de Strombus (Mollusca, Gastropoda, Strombidae). Zoosystema, 32(4):613-623.

Turner, J. R., and R. Klaus. 2005. Coral Reefs of the Mascarenes, Western Indian Ocean. Philosophical Transactions of the Royal Society A, 363:229-250.

Van Tilberg, H. K., D. J. Herdrich, R. Suka, M. Lawrence, C. Filimoehala, and S. Gandulla. 2013. Unlocking the Secrets of Swains Island: A Maritime Heritage Resources Survey. Maritime Heritage Program Series: Number 6. Silver Spring, MD: Office of National Marine Sanctuaries.

Vecsei, A. 2000. Database on Isolated Low-Latitude Carbonate Banks. Facies, 43:205-222.

Wagle, B. D., and P. D. Kunte. 1999. Photo-Geomorphological Study of Representative Islands of Lakshadweep. Gondwana Geological Magazine, 4:203-209.

Wang, P., and Q. Li, eds. 2009. The South China Sea: Paleoceanography and Sedimentology. Dordrecht, Netherlands: Springer Science + Business Media BV.

Wester, L., J. O. Juvik, and P. Holthus. 1992. Vegetation History of Washington Island (Teraina), Northern Line Islands. Atoll Research Bulletin, 358:1-49.

Whistler, W. A. 1983. The Flora and Vegetation of Swains Island. Atoll Research Bulletin, 262:1-25.

Wiens, H. J. 1962. Atoll Environment and Ecology. New Haven, CT: Yale University Press.

Wolff, T. 1970. "Lake Tegano on Rennell Island: The Former Lagoon of a Raised Atoll.” In The Natural History of Rennell Island, British Solomon Islands, Vol. 6, pp. 7-29. Copenhagen: Danish Science Press.

Woodroffe, C. D. 1987. Pacific Island Mangroves: Distribution and Environmental Settings. Pacific Science, 41:166-185.

- 1991. Stratigraphy and Chronology of Late Pleistocene Reefs in the Southern Cook Islands, South Pacific. Quaternary Research, 35:246-263.

- 2008. Reef-Island Topography and the Vulnerability of Atolls to Sea-Level Rise. Global Planetary Change, 62:77-96.

- 2011. "Atolls.” In Encyclopedia of Modern Coral Reefs, Structure, Form and Process, ed. D. Hopley, pp. 51-71. Dordrecht, Netherlands: Springer Science+Business Media BV.

Woodroffe, C. D., D. M. Kennedy, B. G. Jones, and C. V. G. Phipps. 2004. Geomorphology and Late Quaternary Development of Middleton and Elizabeth Reefs. Coral Reefs, 23:249-262.

Woodroffe, C. D., and R. F. McLean. 1998. Pleistocene Morphology and Holocene Emergence of Christmas (Kiritimati) Island, Pacific Ocean. Coral Reefs, 17:235-248.

Woodroffe, C. D., B. Samosorn, Q. Hua, and D. E. Hart. 2007. Incremental Accretion of a Sandy Reef Island over the Past 3000 Years Indicated by Component-Specific Radiocarbon Dating. Geophysical Research Letters, 34, L03602. doi:10.1029/2006GL028875.

Woodroffe, C. D., D. R. Stoddart, T. Spencer, T. P. Scoffin, and A. W. Tudhope.1990. Holocene Emergence in the Cook Islands South Pacific. Coral Reefs, 9:31-39.

Woodroffe, C. D., H. H. Veeh, A. C. Falkland, R. F. McLean, and E. Wallensky. 1991. Last Interglacial Reef and Subsidence of the Cocos (Keeling) Islands, Indian Ocean. Marine Geology, 96:137-143.

Xue, C. 2005. Causes of Land Loss in Tuvalu, a Small Island Nation in the Pacific. Journal of Ocean University of China, 4:115-123. 